\title{
Molluscicides against the snail-intermediate host of Schistosoma: a review
}

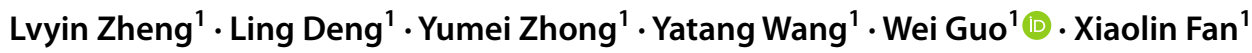

Received: 16 June 2021 / Accepted: 10 August 2021 / Published online: 6 September 2021

(c) The Author(s), under exclusive licence to Springer-Verlag GmbH Germany, part of Springer Nature 2021

\begin{abstract}
Schistosomiasis, a neglected tropical disease (NTD), is one of the most prevalent parasitoses in the World. Certain freshwater snail species are the intermediate host in the life cycle of schistosome species. Controlling snails employing molluscicides is an effective, quick, and convenient intervention strategy to prevent the spread of Schistosoma species in endemic regions. Advances have been made in developing both synthetic molluscicides and molluscicides derived from plants. However, at present, the development of molluscicides is not adapted to the actual demand for snails and schistosoma controlling. We undertake a systematic review of exploitation and application of synthetic molluscicides and molluscicides derived from plants to combat intermediate host snails. The detailed molluscicidal activity, structure-activity relationship, structural feature, and possible mechanism of some molluscicides are also highlighted, which may afford an important reference for the design of new, more effective molluscicides with low environmental impact and realize the aim of controlling schistosome at transmission stages.
\end{abstract}

Keywords Molluscicides $\cdot$ Schistosoma $\cdot$ Snails $\cdot$ Molluscicidal activity $\cdot$ Mechanism

\section{Introduction}

Schistosomiasis, a neglected tropical disease (NTD), is one of the most important infectious parasitoses of humans and animals in the tropical and subtropical regions (Njoroge et al. 2014; Thétiot-Laurent et al. 2013). It is estimated that schistosomiasis could affect more than 200 million people in approximately 70 countries (WHO (World Health Organization) 2021, 2020). About 700 million people live in endemic area (Colley et al. 2014). Six species of the genus Schistosoma including S. japonicum, S. mansoni, S. haematobium, $S$. mekongi, $S$. malayensis, and $S$. intercalatum can cause disease in people (Gryseels et al. 2006). The life cycle of the

Section Editor: Christoph G. Grevelding

Lvyin Zheng and Ling Deng contributed equally

Wei Guo

guoweigw@126.com

$\bowtie$ Xiaolin Fan

fanxl@ecut.edu.cn

1 Key Laboratory of Organo-Pharmaceutical Chemistry of Jiangxi Province, Gannan Normal University, Ganzhou 341000, China parasite is complex with an intermediate host (Oncomelania snails), definitive host (humans and mammals), and seven lifecycle stages involving the adult worm, egg, miracidium, mother sporocyst, daughter sporocyst, cercariae, and schistosomulum (Colley et al. 2014; Guo et al. 2008, 2015). It is a great challenge to control schistosomiasis in undeveloped regions because of financial burden and environmental pressures. The current strategies for schistosomiasis control mainly rely on snail control, drug treatment (such as Praziquantel), advanced sanitation, and health education (Limpanont et al. 2020). Although the present method for the control of schistosomiasis is largely based on drug treatment, snail control using molluscicides still plays a crucial role (de Souza 1995; Yuan et al. 2005; Wang et al. 2009).

There are three major species of snails acting as the intermediate hosts: Oncomelania hupensis (O. hupensis) for $S$. japonicum, Biomphalaria species for S. mansoni, and Bulinus species for S. haematobium (Sturrock 1995). At present, three main strategies including biological control, ecological control, and molluscicidal control have been carried out for the control of schistosome snails (Lardans and Dissous 1998; McCullough et al. 1980). For biological control, some natural predators of snails such as aquatic birds, turtles, fish, crayfish, and insects have been considered as well as 
competitor snails (Madsen 1990; Ohmae et al. 2003; Pointier and Jourdane 2000; Li et al. 2016). Furthermore, some small creatures such as trematodes, leeches, nematodes, rotifers, and ostracods can attack or devour the snails (Younes et al. 2017). However, the above biological control experiments were often investigated in the laboratory; further field studies are essential in evaluating the control of the snails. The ecological control is also a useful approach including advanced sanitation, agricultural and hydrological exploitation and management (Dong et al. 2018; Liang et al. 2018). However, the potential risk factors are negligible including the limited natural resources, extreme climate changes, and severe financial burden (Lo et al. 2018).

Up to now, the application of molluscicides is the most effective intervention strategy for the control of snails in endemic regions (King et al. 2015). For example, chemical treatment using molluscicides was performed in an area of $78,308.26$ hectare in China, and environmental improvements were only carried out in an area of 4738.37 hectare in 2018 (Zhang et al. 2019). Great efforts have been made to explore all kinds of molluscicidal substances including chemical and plant molluscicides (Perrett and Whitfield 1996; de Paula-Andrade et al. 2019). Herein, we undertake a systematic review of molluscicides, and their detailed molluscicidal activity, structure-activity relationship, and possible mechanism of some molluscicides are also highlighted.

\section{Development of chemical molluscicides}

\section{Inorganic salts}

\section{Copper sulfate (CuSO $\left.{ }_{4}\right)$}

Copper sulfate (compound 1, Table 1, Tab. S1, see Supplementary materials) was evaluated as molluscicides to combat $B$. alexandrina snails in Egypt (Hoffman and Zakhary 1953). The mortality of snails could reach $100 \%$ within 2 weeks at $0.25 \mathrm{ppm}$. Copper sulfate is an inexpensive inorganic salt. However, the toxicity of the molluscicides on non-target organisms and secondary environmental pollution issues are not ignorable.

\section{Calcium cyanamide}

Calcium cyanamide (2, Table 1 ) was previously reported as an efficient molluscicide for $O$. hupensis and has low toxicity for fish and other aquatic animals (Wei et al. 2008). The mortality of snails was up to $100 \%$ after 2 days at $80 \mathrm{ppm}$ in immersion experiments, which is not good for a molluscicide. In pesticide spraying experiments in the laboratory, the mortality of snails was also $100 \%$ after 1 day with the concentration of $30 \mathrm{~g} / \mathrm{m}^{2}$. While in natural field conditions, the mortality of snails was $97.18 \%$ at $50 \mathrm{ppm}$. In the field spraying experiments, the mortalities of snails were $81.11 \%$ and $96.03 \%$ in the concentrations of 30 and $50 \mathrm{~g} / \mathrm{m}^{2}$ in 15 days, respectively (Wei et al. 2008). Calcium cyanamides exhibited low toxicity to other aquatic animals at the effective concentration. Further molluscicidal mechanism investigation showed that calcium cyanamide could damage epithelial cells, hepatocytes, and muscle cells of snails (Xia et al. 2010). However, for calcium cyanamide, the toxicological explorations are worth of further investigation for practical applications.

\section{Organic molluscicides}

\section{Sodium 2,3,4,5,6-pentachlorophenolate (NaPCP) and its derivatives}

Sodium 2,3,4,5,6-pentachlorophenolate (3, Table 1) was found to have molluscicidal activity $\left(\mathrm{LC}_{50}=0.54 \mathrm{ppm}\right.$, $\mathrm{LC}_{100}=2.0 \mathrm{ppm}, 48 \mathrm{~h}$ ) in immersion experiments (Moon et al. 1958; Zhang et al. 2006). In field experiments, NaPCP was effective at dosages of 10-20 ppm (immersion method) and $5-10 \mathrm{~g} / \mathrm{m}^{2}$ (spraying method). Furthermore, NaPCP could kill snail eggs, young snails, and adult snails (Zhang et al. 2006). However, NaPCP has toxicity against fish, aquatic animals, and mammals, along with the risk of teratogenicity, carcinogenesis, and mutagenicity (Xi et al. 2016). In addition, the technical products of NaPCP often contain highly toxic tetrachloro dibenzodioxines and dibenzofuranes, and that these agents can also arise from light exposure or heat (fire) of pentachlorophenol-contaminated objects. Subsequently, the molluscicidal activity of sodium 2,5-dichloro-4-bromophenol (4, Table 1) was explored for the control of $O$. nasophora in immersion experiments (Kajihara et al. 1979). The $\mathrm{LC}_{50}$ and $\mathrm{LC}_{90}$ values of sodium 2,5-dichloro-4-bromophenol were $0.54 \mathrm{ppm}$ and $1.59 \mathrm{ppm}$. Additionally, this compound showed lower toxicity than NaPCP for carp, rainbow trout, and killifish.

\section{$N$-Bromoacetamide and its derivatives}

$\mathrm{N}$-Bromoacetamide (5, Table 1) exhibited molluscicidal activity against adult snails, young snails, and snail eggs, and low toxicity to fish (Zhu et al. 1984). The $\mathrm{LC}_{50}$ and $\mathrm{LC}_{90}$ values were $0.64 \mathrm{ppm}$ and $1.0 \mathrm{ppm}$ in immersion experiments in $24 \mathrm{~h}$, respectively. The mortality of snails exceeded $80 \%$ after 7 days at a surface concentration of $1 \mathrm{~g} / \mathrm{m}^{2}$ in spraying tests (Zhu et al. 1984). In particular, $\mathrm{N}$-bromoacetamide has the advantages of low-dosage, good solubility in water, low toxicity and non-mutagenicity, which may be an ideal molluscicidal candidate. Nicotinanilide (6, Table 1) was also found to have the same molluscicidal activity as $N$-bromoacetamide (Sukumaran 
Table. 1 The chemical structure and molluscicidal activity of molluscicides

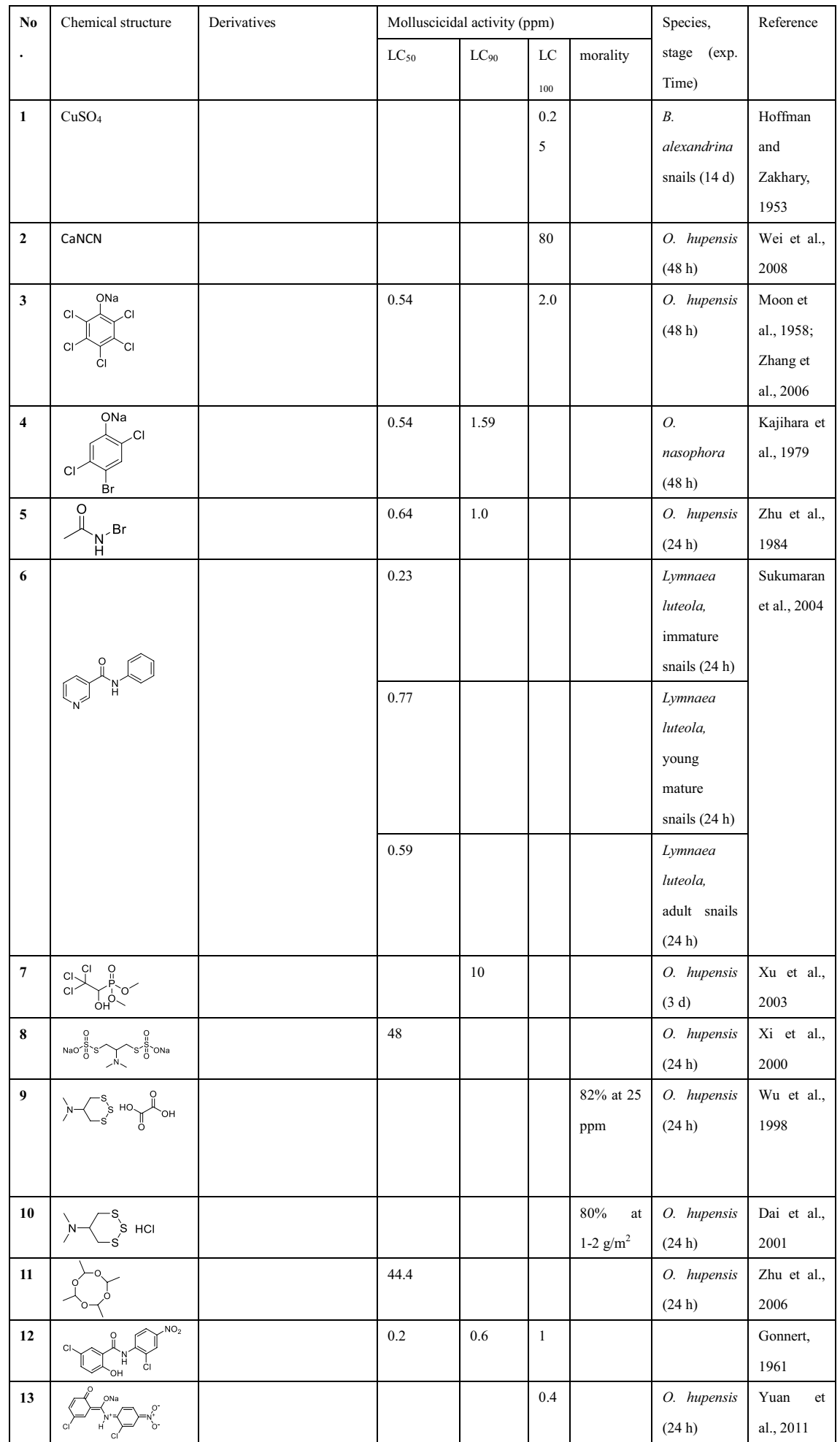

et al. 2004). The $\mathrm{LC}_{50}$ values of nicotinanilide against different stages of snails were $0.23 \mathrm{ppm}$ (immature snails), $0.77 \mathrm{ppm}$ (young mature snails), and $0.59 \mathrm{ppm}$ (adult snails) in $24 \mathrm{~h}$, respectively. In field immersion experiments, nicotinanilide could kill $95 \%$ of the snails at the concentration of 1-2 ppm in 3 days. Nicotinanilide was also harmless to humans, animals, fish, and plant (Sukumaran et al. 2004). Disadvantages include strong irritation to human skin, low toxicity to snail eggs, and high cost, which seriously restrict the large-scale application of the molluscicide. 
Table. 1 (continued)

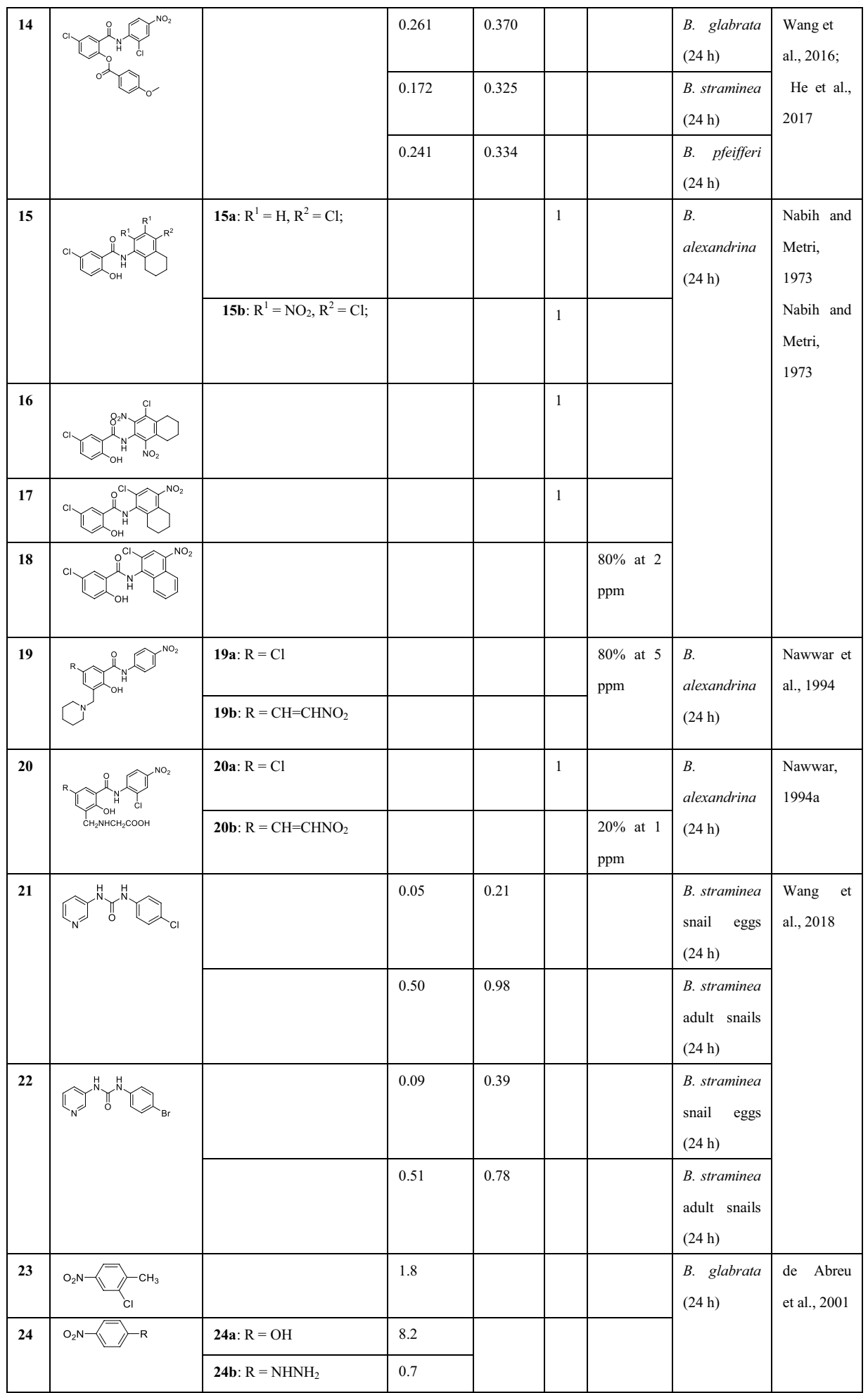

\section{Dipterex}

Dipterex (7, Table 1) is an important organic phosphorous pesticide. Dipterex displayed promising molluscicidal activity, and the mortality of snails was $96 \%$ at $10 \mathrm{ppm}$ in 3 days (Xu et al. 2003). After treatment, the head and foot of snails were paralyzed, and snails began to die out slowly. 
Table. 1 (continued)

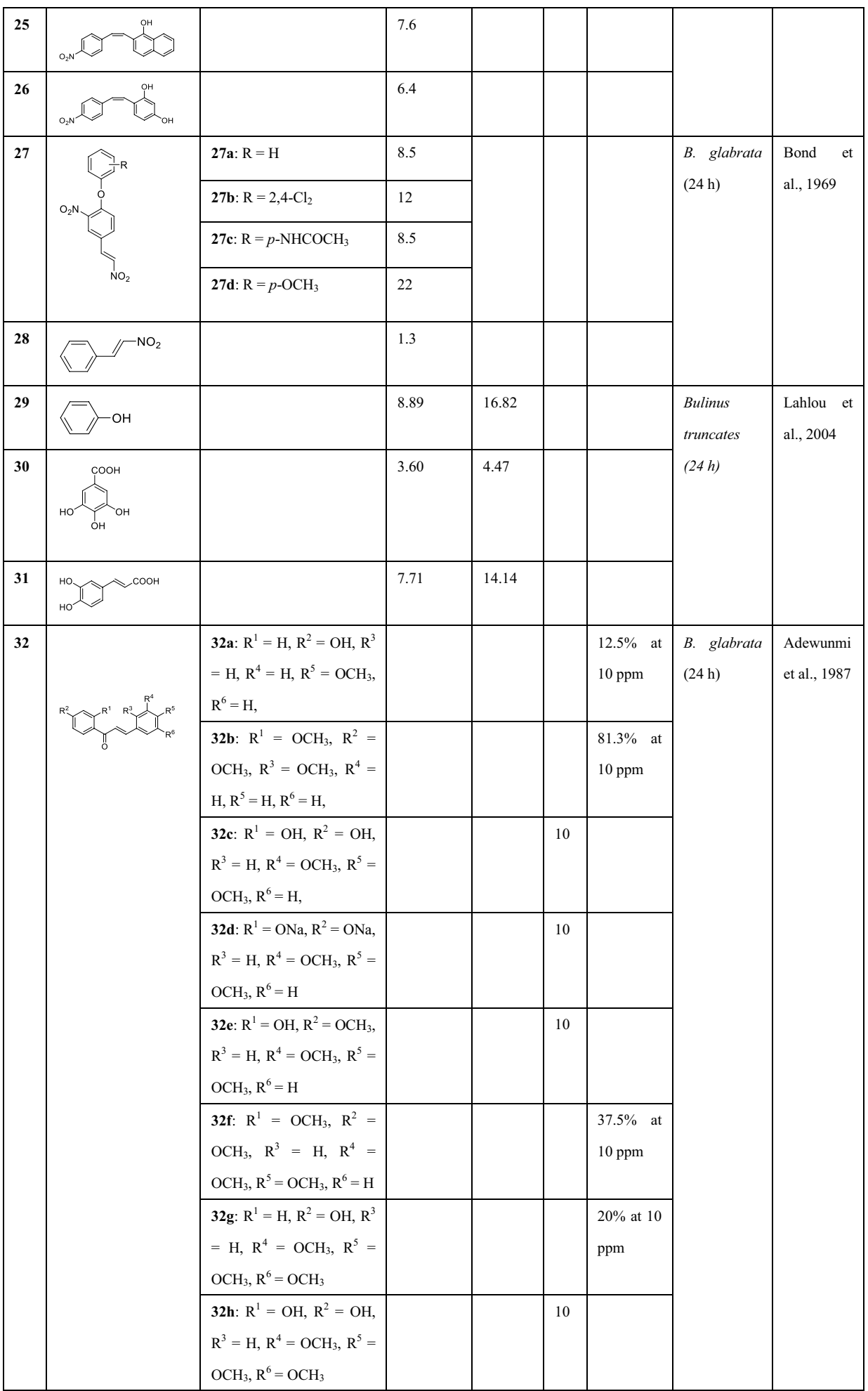

\section{Nereistoxin pesticides}

Nereistoxin pesticides are important bionic pesticides derived from nereistoxin. These compounds have attracted more attention because of their low toxicity and residue to fish and aquatic animals. The representative nereistoxin pesticides are bisultap (8, Table 1), thiocyclam hydrogen oxalate (9, Table 1), and trithialan (10, Table 1) (Wu 2007). The $\mathrm{LC}_{50}$ of bisultap 8 was $48 \mathrm{ppm}$ in $24 \mathrm{~h}$. Mortality among snails reached $100 \%$ at $20 \mathrm{ppm}$ in $72 \mathrm{~h}$ in immersion tests (Xi et al. 2000). For bisultap 8, the mortality of snails was up to $100 \%$ in spraying experiments 
Table. 1 (continued)

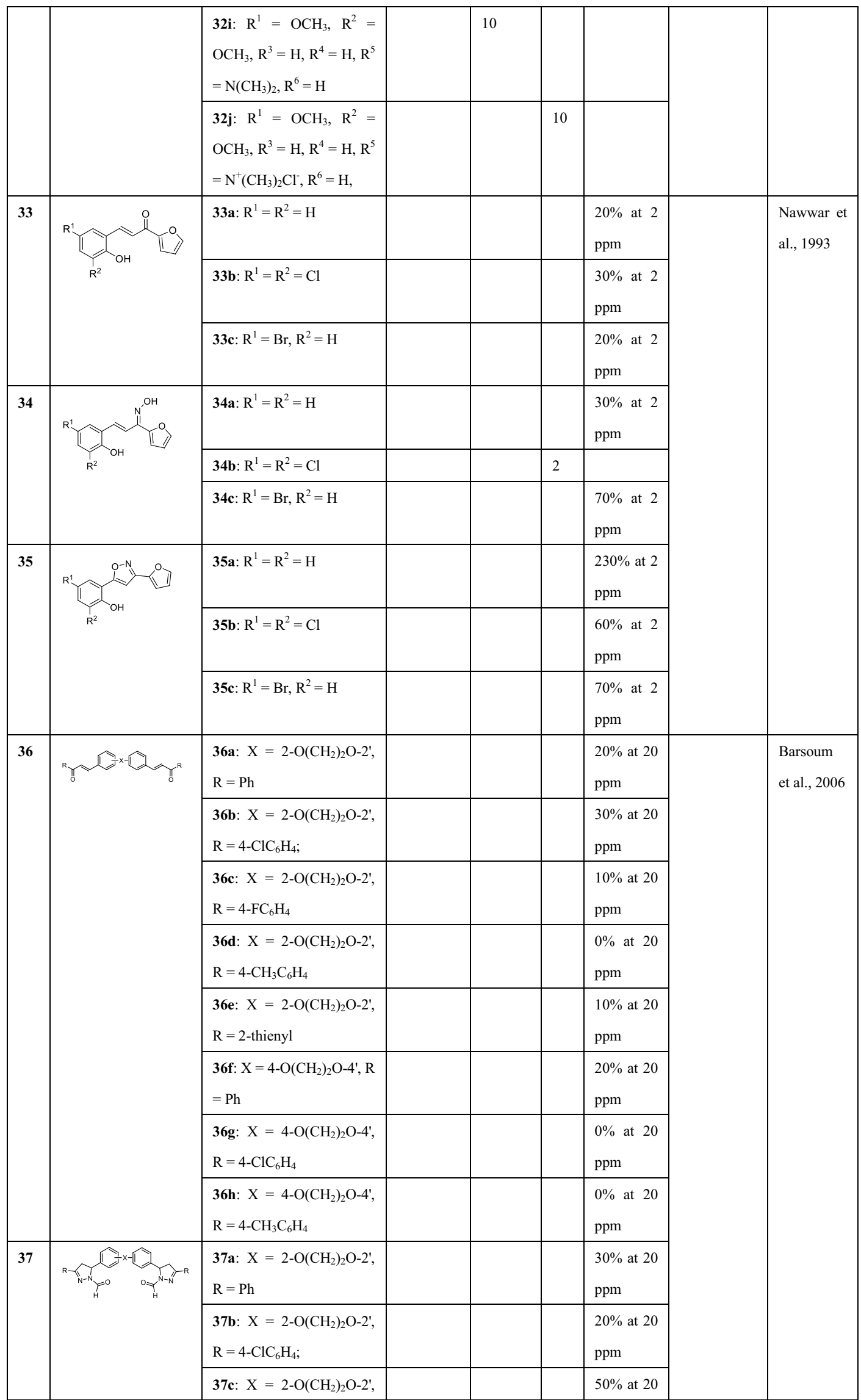


Table. 1 (continued)

\begin{tabular}{|c|c|c|c|c|c|c|c|c|}
\hline & & $\mathrm{R}=4-\mathrm{FC}_{6} \mathrm{H}_{4}$ & & & & ppm & & \\
\hline & & $\begin{array}{l}\text { 37d: } \mathrm{X}=2-\mathrm{O}\left(\mathrm{CH}_{2}\right)_{2} \mathrm{O}-2 \\
\mathrm{R}=4-\mathrm{CH}_{3} \mathrm{C}_{6} \mathrm{H}_{4}\end{array}$ & & & & $\begin{array}{l}10 \% \text { at } 20 \\
\text { ppm }\end{array}$ & & \\
\hline & & $\begin{array}{l}\text { 37e: } \mathrm{X}=2-\mathrm{O}\left(\mathrm{CH}_{2}\right)_{2} \mathrm{O}-2 \text {, } \\
\mathrm{R}=2 \text {-thienyl }\end{array}$ & & & & $\begin{array}{l}20 \% \text { at } 20 \\
\text { ppm }\end{array}$ & & \\
\hline & & $\begin{array}{l}\text { 37f: } \mathrm{X}=4-\mathrm{O}\left(\mathrm{CH}_{2}\right)_{2} \mathrm{O}-4^{\prime}, \mathrm{R} \\
=\mathrm{Ph}\end{array}$ & & & & $\begin{array}{l}40 \% \text { at } 20 \\
\text { ppm }\end{array}$ & & \\
\hline & & $\begin{array}{l}\text { 37g: } \mathrm{X}=4-\mathrm{O}\left(\mathrm{CH}_{2}\right)_{2} \mathrm{O}-4 \\
\mathrm{R}=4-\mathrm{ClC}_{6} \mathrm{H}_{4}\end{array}$ & & & & $\begin{array}{l}30 \% \text { at } 20 \\
\text { ppm }\end{array}$ & & \\
\hline & & $\begin{array}{l}\text { 37h: } \mathrm{X}=4-\mathrm{O}\left(\mathrm{CH}_{2}\right)_{2} \mathrm{O}-4, \\
\mathrm{R}=4-\mathrm{CH}_{3} \mathrm{C}_{6} \mathrm{H}_{4}\end{array}$ & & & & $\begin{array}{l}0 \% \text { at } 20 \\
\text { ppm }\end{array}$ & & \\
\hline 38 & & & 6.64 & 9.23 & & & $\begin{array}{l}\text { B. glabrata } \\
(24 \mathrm{~h})\end{array}$ & $\begin{array}{l}\text { Vasconcell } \\
\text { os et al., } \\
2006\end{array}$ \\
\hline 39 & & & 7.30 & 10.64 & & & & \\
\hline 40 & & & 17.1 & 22.7 & & & & \\
\hline \multirow[t]{3}{*}{41} & & 41a: $\mathrm{Ar}=4-\mathrm{ClC}_{6} \mathrm{H}_{4}$ & 0.6043 & & & & \multirow{6}{*}{$\begin{array}{l}\text { Indoplanorb } \\
\text { is exustus } \\
(24 \mathrm{~h})\end{array}$} & \multirow{6}{*}{$\begin{array}{l}\text { Kanawade } \\
\text { et al., } 2011\end{array}$} \\
\hline & & 41b: $\mathrm{Ar}=3,5-\left(\mathrm{CF}_{3}\right)_{2} \mathrm{C}_{6} \mathrm{H}_{3}$ & 0.7506 & & & & & \\
\hline & & 41c: $\mathrm{Ar}=2,4-\mathrm{F}_{2} \mathrm{C}_{6} \mathrm{H}_{3}$ & 0.6067 & & & & & \\
\hline \multirow[t]{3}{*}{42} & & 42a: $\mathrm{Ar}=4-\mathrm{ClC}_{6} \mathrm{H}_{4}$ & 0.6511 & & & & & \\
\hline & & 42b: $\mathrm{Ar}=3,5-\left(\mathrm{CF}_{3}\right)_{2} \mathrm{C}_{6} \mathrm{H}_{3}$ & 0.7403 & & & & & \\
\hline & & 42c: $\mathrm{Ar}=2,4-\mathrm{F}_{2} \mathrm{C}_{6} \mathrm{H}_{3}$ & 0.7628 & & & & & \\
\hline \multirow[t]{4}{*}{43} & & 43a: $\mathrm{R}=\mathrm{Ph}$ & 15.6 & 20 & & & \multirow{8}{*}{$\begin{array}{l}B . \\
\text { alexandrina } \\
(24 \mathrm{~h})\end{array}$} & \multirow{8}{*}{$\begin{array}{l}\text { Fadda et } \\
\text { al., } 2009\end{array}$} \\
\hline & & 43b: $\mathrm{R}=\mathrm{OH}$ & 19 & 23 & & & & \\
\hline & & 43c: $\mathrm{R}=\mathrm{OEt}$ & 18 & 20 & & & & \\
\hline & & 43d: $\mathrm{R}=\mathrm{CH}_{3}$ & 16 & 22 & & & & \\
\hline \multirow[t]{3}{*}{44} & & 44a: $\mathrm{Ar}=\mathrm{Ph}$ & 8 & 10 & & & & \\
\hline & & 44b: $\mathrm{Ar}=p-\mathrm{CH}_{3}-\mathrm{C}_{6} \mathrm{H}_{4}$ & 5.5 & 9 & & & & \\
\hline & & 44c: $\mathrm{Ar}=p-\mathrm{CH}_{3} \mathrm{O}-\mathrm{C}_{6} \mathrm{H}_{4} \mathrm{Ph}$ & 6 & 11 & & & & \\
\hline 45 & & & 13 & 18 & & & & \\
\hline 46 & & & & & 10 & & \multirow{3}{*}{$\begin{array}{l}B . \\
\text { alexandrina } \\
(24 \mathrm{~h})\end{array}$} & \multirow[t]{3}{*}{$\begin{array}{l}\text { El Shehry } \\
\text { et al., } 2010\end{array}$} \\
\hline 47 & & & & & 10 & & & \\
\hline 48 & $\langle\nabla-0$ & & & & & $\begin{array}{l}80 \% \text { at } 10 \\
\text { ppm }\end{array}$ & & \\
\hline
\end{tabular}

at a surface concentration of $10 \mathrm{~g} / \mathrm{m}^{2}$ in $24 \mathrm{~h}$ (Xi et al. 2000). Thiocyclam hydrogen oxalate 9 also displayed the high molluscicidal activity, and the mortality of snails exceeded $82 \%$ in immersion experiments $(25 \mathrm{ppm})$ and spraying experiments $\left(2.5-5 \mathrm{~g} / \mathrm{m}^{2}\right)$ in $24 \mathrm{~h}$ (Wu et al. 1998). Trithialan (10) had molluscicidal activity at the surface concentration of $1-2 \mathrm{~g} / \mathrm{m}^{2}$ in 3 days, and the mortality of snails exceeded $80 \%$ in field experiments (Dai et al. 2001). The structural relationships of nereistoxin pesticides showed that the cyclic compounds $\mathbf{9}$ and $\mathbf{1 0}$ have stronger molluscicidal activities than compound $\mathbf{8}$, and compound $\mathbf{1 0}$ has excellent activities in the condition 
Table. 1 (continued)

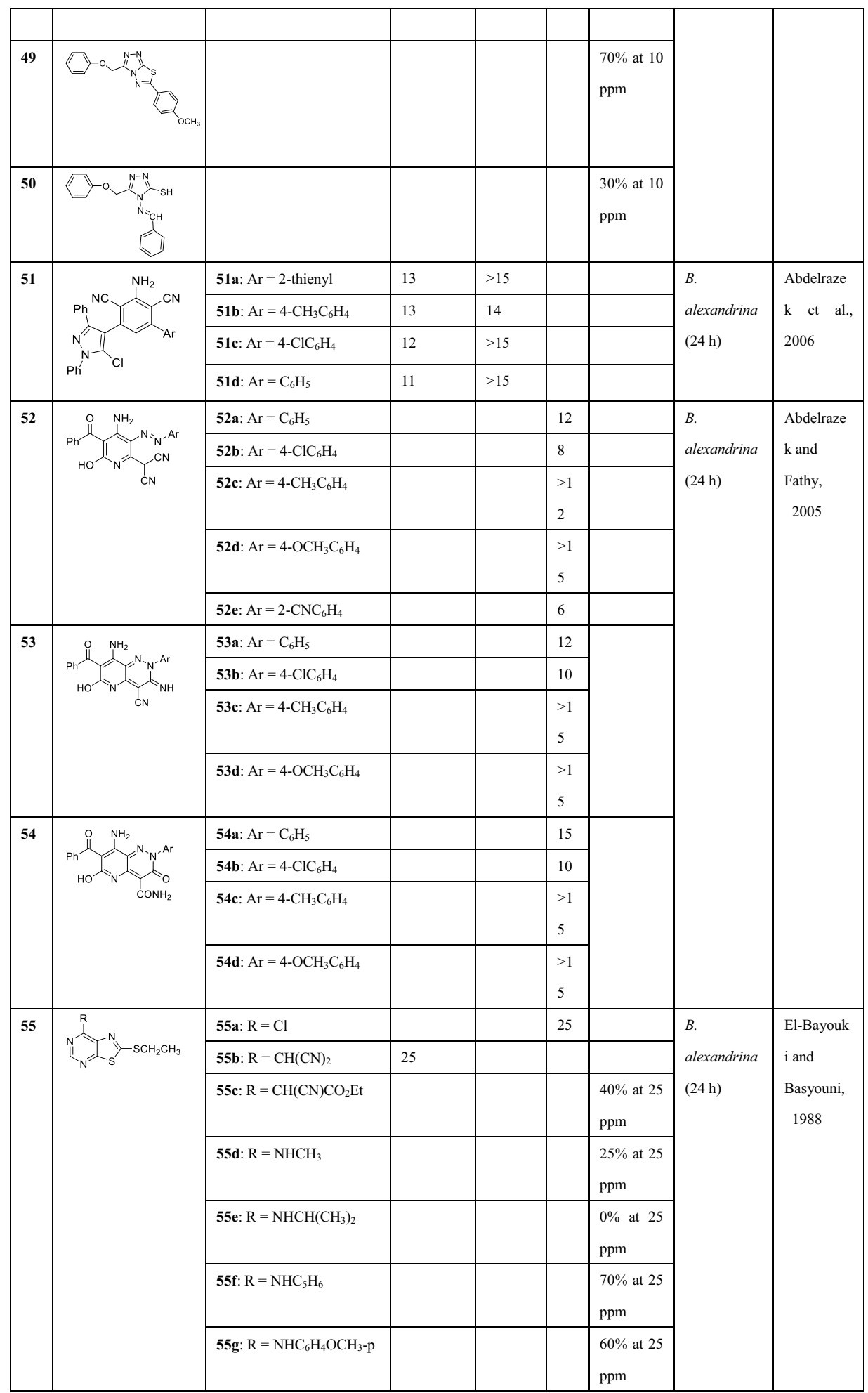

of high humidity and high temperature (Wu 2007). As a green molluscicide, trithialan $\mathbf{1 0}$ has the features of less pollution, good solubility in water, and convenient operation, which can also inhibit snails moving. However, the real molluscicidal activity of the above molluscicides was easily influenced by the surroundings.

\section{Metaldehyde}

Metaldehyde (11, Table 1) (the formulation of $40 \%$ water emulsion) exhibited good molluscicidal and climbing-inhibition activity against snails in laboratory and field experiments (Zhu et al. 2006). The $\mathrm{LC}_{50}$ values of metaldehyde 
Table. 1 (continued)

\begin{tabular}{|c|c|c|c|c|c|c|c|c|}
\hline & & 55h: R = NH-thiazolyl & & & & $\begin{array}{l}25 \% \text { at } 25 \\
\text { ppm }\end{array}$ & & \\
\hline & & 55i: $\mathrm{R}=\mathrm{NHCH}_{2}$ furyl & & & 25 & & & \\
\hline 56 & 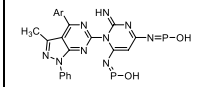 & & & & & $\begin{array}{l}30 \% \text { at } 50 \\
\text { ppm }\end{array}$ & \multirow{2}{*}{\begin{tabular}{|l}
$B$. \\
alexandrina \\
$(24 \mathrm{~h})$
\end{tabular}} & \multirow{2}{*}{$\begin{array}{l}\text { Bakhotma } \\
\text { h et al., } \\
2019\end{array}$} \\
\hline 57 & $\mathrm{H}_{3} \mathrm{C}_{\pi}^{A}$ & & & & & $\begin{array}{l}30 \% \text { at } 50 \\
\text { ppm }\end{array}$ & & \\
\hline \multirow[t]{3}{*}{58} & & 58a: $\mathrm{Ar}=\mathrm{Ph}$ & 8 & 11 & & & \multirow{6}{*}{$\begin{array}{l}B . \\
\text { alexandrina } \\
(24 \mathrm{~h})\end{array}$} & \multirow{6}{*}{$\begin{array}{l}\text { Abdelraze } \\
k \text { et al. } \\
2006 a\end{array}$} \\
\hline & & 58b: $\mathrm{Ar}=4-\mathrm{Me}-\mathrm{C}_{6} \mathrm{H}_{4}$ & 7 & 15 & & & & \\
\hline & & 58c: $\mathrm{Ar}=4-\mathrm{Cl}-\mathrm{C}_{6} \mathrm{H}_{4}$ & 7 & 9 & & & & \\
\hline \multirow[t]{3}{*}{59} & & 59a: $\mathrm{Ar}=\mathrm{Ph}$ & 8 & 13 & & & & \\
\hline & & 59b: $\mathrm{Ar}=4-\mathrm{Me}-\mathrm{C}_{6} \mathrm{H}_{4}$ & 9 & $>15$ & & & & \\
\hline & & 59c: $\mathrm{Ar}=4-\mathrm{Cl}_{-} \mathrm{C}_{6} \mathrm{H}_{4}$ & 7 & 9 & & & & \\
\hline 60 & & & & & & $\begin{array}{l}30 \% \text { at } 50 \\
\text { ppm }\end{array}$ & \multirow{3}{*}{$\begin{array}{l}B . \\
\text { alexandrina } \\
(24 \mathrm{~h})\end{array}$} & \multirow[t]{3}{*}{$\begin{array}{l}\text { Ali et al., } \\
2008\end{array}$} \\
\hline 61 & $\begin{array}{l}\text { Ar } \\
\text { Ar }\end{array}$ & & & & & $\begin{array}{l}20 \% \text { at } 50 \\
\text { ppm }\end{array}$ & & \\
\hline 62 & & & & & & $\begin{array}{l}30 \% \text { at } 50 \\
\text { ppm }\end{array}$ & & \\
\hline 63 & & & & & 50 & & \multirow[t]{4}{*}{$\begin{array}{l}B . \\
\text { alexandrina } \\
(24 \mathrm{~h})\end{array}$} & \multirow[t]{4}{*}{$\begin{array}{l}\text { Abdel-Rah } \\
\text { man et al., } \\
2003\end{array}$} \\
\hline 64 & & & & & & $\begin{array}{l}20 \% \text { at } 50 \\
\text { ppm }\end{array}$ & & \\
\hline 65 & 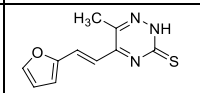 & & & & & $\begin{array}{l}0 \% \text { at } 50 \\
\text { ppm }\end{array}$ & & \\
\hline 66 & (1) & & & & & $\begin{array}{l}30 \% \text { at } 50 \\
\text { ppm }\end{array}$ & & \\
\hline 67 & & & 9 & 13 & & & $\begin{array}{l}B . \\
\text { alexandrina } \\
(24 \mathrm{~h})\end{array}$ & $\begin{array}{l}\text { Abdelraze } \\
\text { ket al., } \\
2006\end{array}$ \\
\hline 68 & & & 62.599 & 96.954 & & & \multirow[t]{3}{*}{$\begin{array}{l}\text { B. glabrata } \\
\text { egg masses } \\
(96 \mathrm{~h})\end{array}$} & \multirow[t]{3}{*}{$\begin{array}{l}\text { de Souza } \\
\text { et al., } 2004\end{array}$} \\
\hline 69 & & & 23.031 & 40.262 & & & & \\
\hline 70 & & 70a: $\mathrm{R}=\mathrm{H}$ & 24.700 & 39.399 & & & & \\
\hline
\end{tabular}

were $0.78 \mathrm{~g} / \mathrm{m}^{2}$ (in $24 \mathrm{~h}$ ), $0.44 \mathrm{~g} / \mathrm{m}^{2}$ (in $48 \mathrm{~h}$ ), and $0.46 \mathrm{~g} /$ $\mathrm{m}^{2}$ (in $72 \mathrm{~h}$ ) in spraying experiments, respectively. When 
Table. 1 (continued)

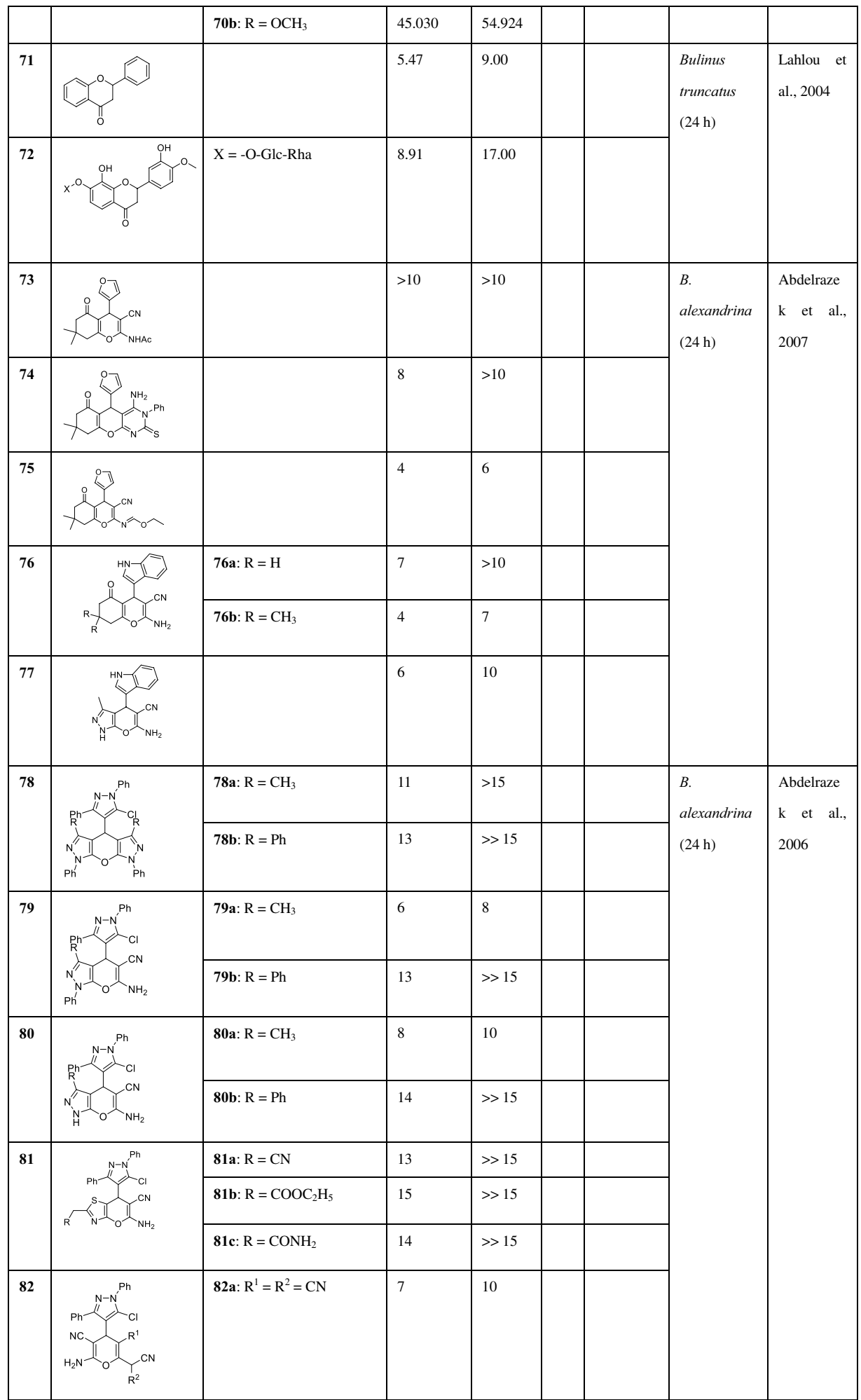

snails were immersed in the solution of metaldehydes, the molluscicides also showed high activity $\left(\mathrm{LC}_{50}=44.4 \mathrm{ppm}\right.$, 24 h; 27.4 ppm, 48 h; 24.8 ppm, 72 h, respectively). The mortality of snails exceeded $90 \%$ after 7 days at $2 \mathrm{~g} / \mathrm{m}^{2}$ in spraying experiments. 
Table. 1 (continued)

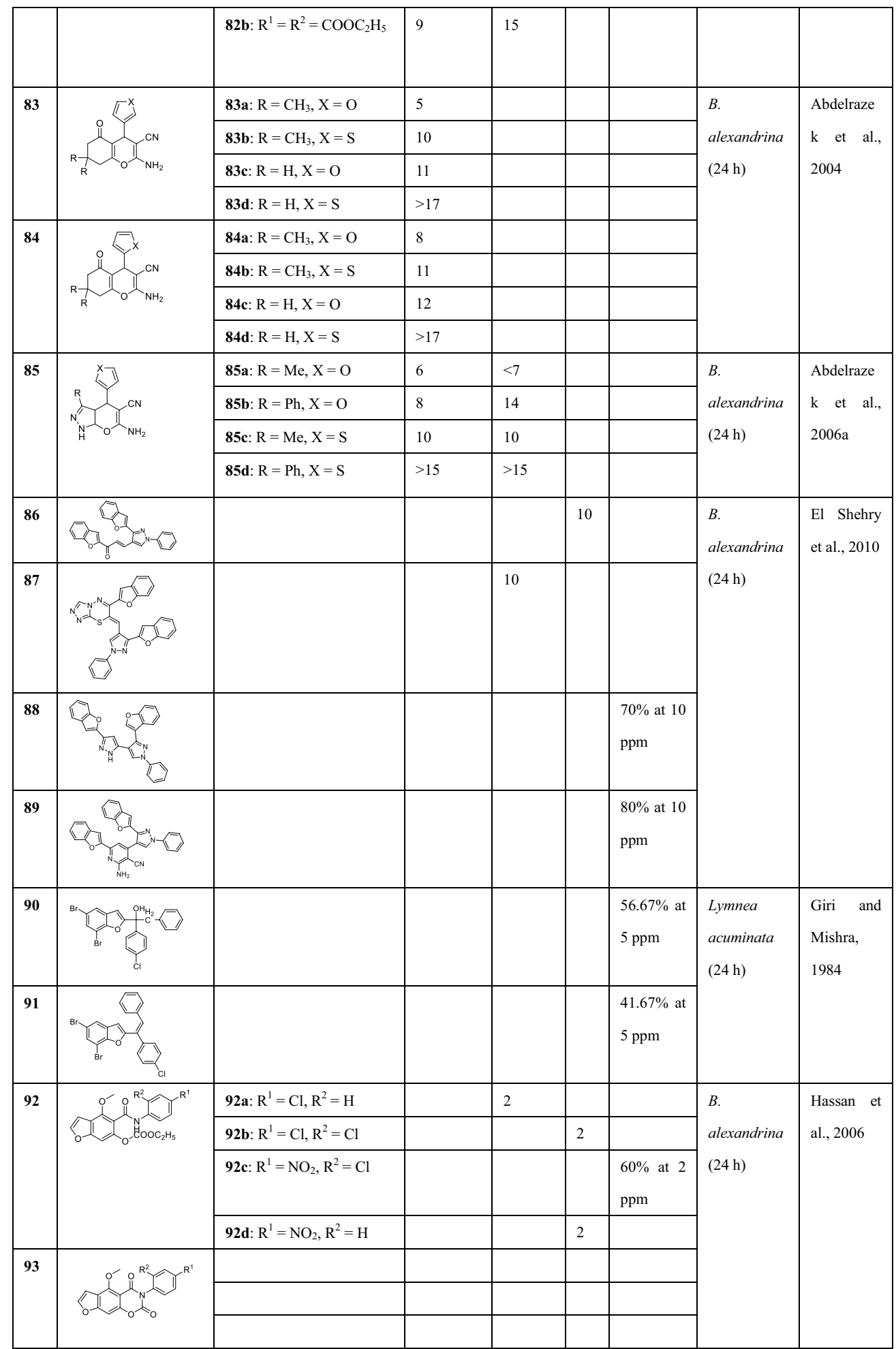

\section{Niclosamide and its derivatives}

Niclosamide (12, Table 1) (named Bayer-73) was reported for its molluscicidal activity $\left(\mathrm{LC}_{50}=0.2 \mathrm{ppm}\right.$; $\left.\mathrm{LC}_{90}=0.6 \mathrm{ppm} ; \mathrm{LC}_{100}=1 \mathrm{ppm}\right)$ by Gonnert and Schranfstatler at the sixth International Congress for Tropical
Medicine and Malaria 1959 (Gonnert 1961). Niclosamide displayed strong molluscicidal activity against different kinds of snails, and its $\mathrm{LC}_{50}$ values for B. glabrata, $B$. straminea, and B. pfeifferi were $0.070 \mathrm{ppm}, 0.049 \mathrm{ppm}$, and $0.076 \mathrm{ppm}$, respectively (He et al. 2017). Importantly, adult snails, young snails, and snail eggs are sensitive to 
Table. 1 (continued)

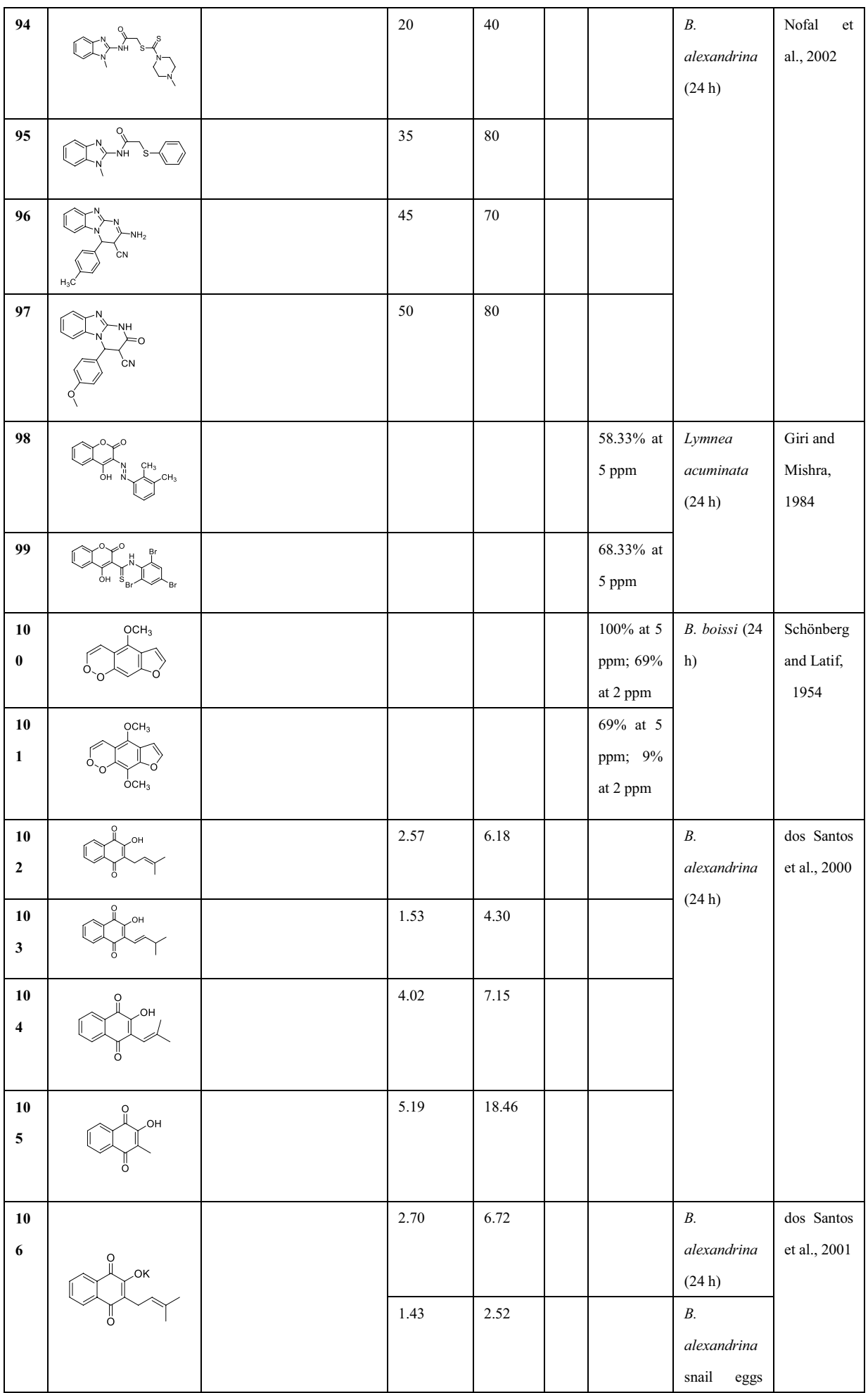

niclosamide (He et al. 2017). Now, niclosamide is the only molluscicide recommended by the World Health Organization (WHO) because of its high efficiency, low toxicity to mammals, and low concerns of pesticide residue (WHO (World Health Organization) 1993). However, niclosamide has the disadvantages of poor solubility in water, high toxicity to fish and other non-target biota, which can induce upward climbing movement for snails.

To solve the solubility problem of niclosamide, $50 \%$ wettable powder of niclosamide ethanolamine salt (WPN) has been prepared from niclosamide ethanolamine salts, fillers, dispersants, and wetting agents. Yang et al. tested 
Table. 1 (continued)

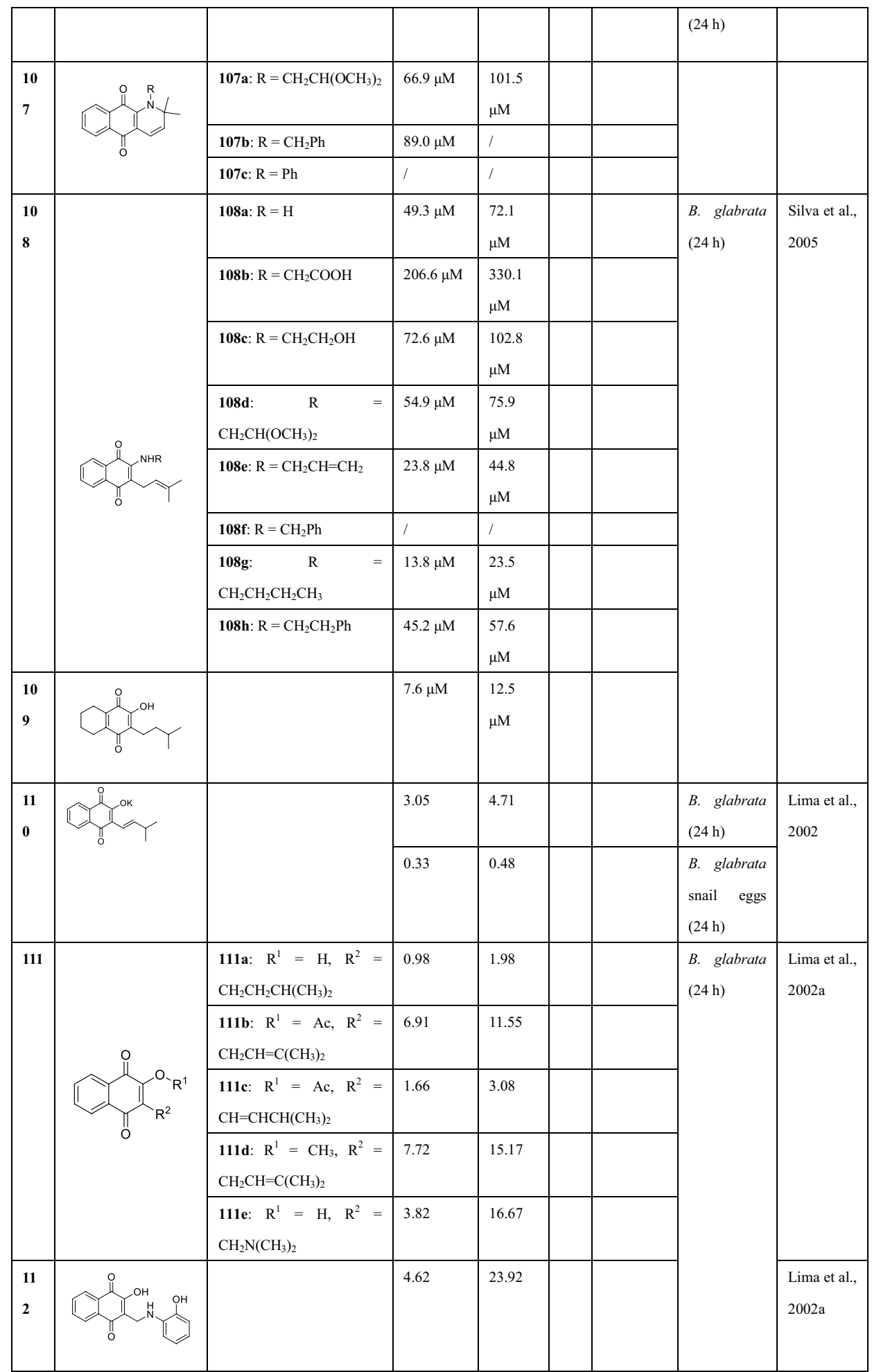

the field molluscicidal activity of WPN in the marshland of an island along the Yangtze River (Jiangsu province, P. R. China) (Yang et al. 2012). WPN was sprayed once, twice, trice, and four times in three different types of regions including low-density, medium-density, and high-density snail groups. The mortality of snails increased with the increasing times of molluscicide applications (Yang et al. 2010).

Although some surfactants were added into the WPN to form small suspended particles, however, the WPN formulation could be easily destroyed during transportation and storage, and formed large scales of niclosamide particles, 
Table. 1 (continued)

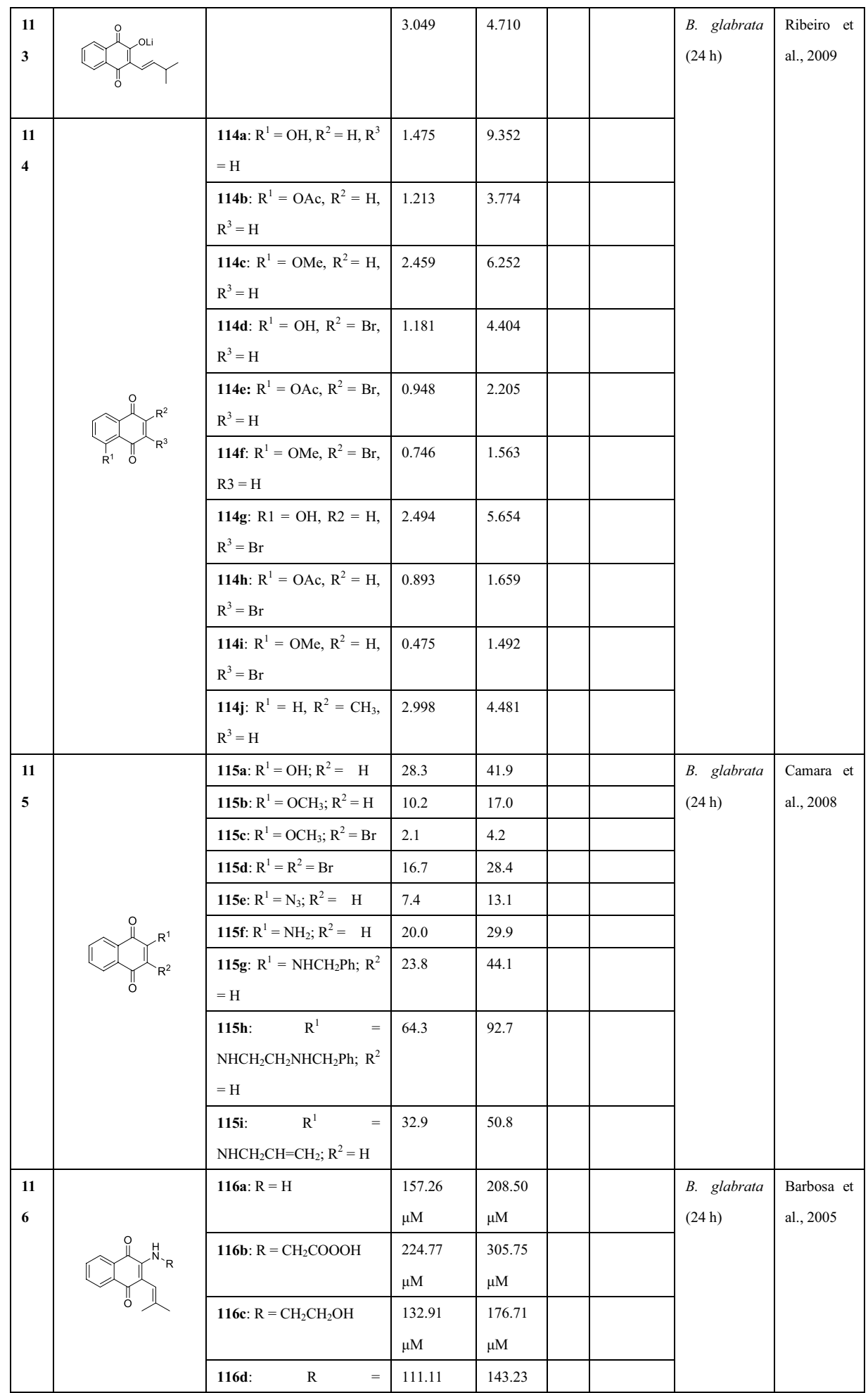

resulting in poor dispersion performance in water. Therefore, $4 \%$ niclosamide ethanolamine salt dust powder (4\% NESDP) was prepared from niclosamide ethanolamine salt, fillers, and auxiliaries. He et al. tested the molluscicidal activity of 4\% NESDP and WPN in hilly areas (He et al. 2007). The molluscicidal activity of $4 \%$ NESDP was significantly higher than that of WPN in the ditches without clearing away grasses after 3, 7, and 15 days. When the experiments were carried out in the slope lands, the activity of $4 \%$ NESDP was also significantly higher than that of WPN after 3, 7, and 15 days. Therefore, $4 \%$ NESDP should be more suitable for application in arid and semi-arid areas (He et al. 2007). 
Table. 1 (continued)

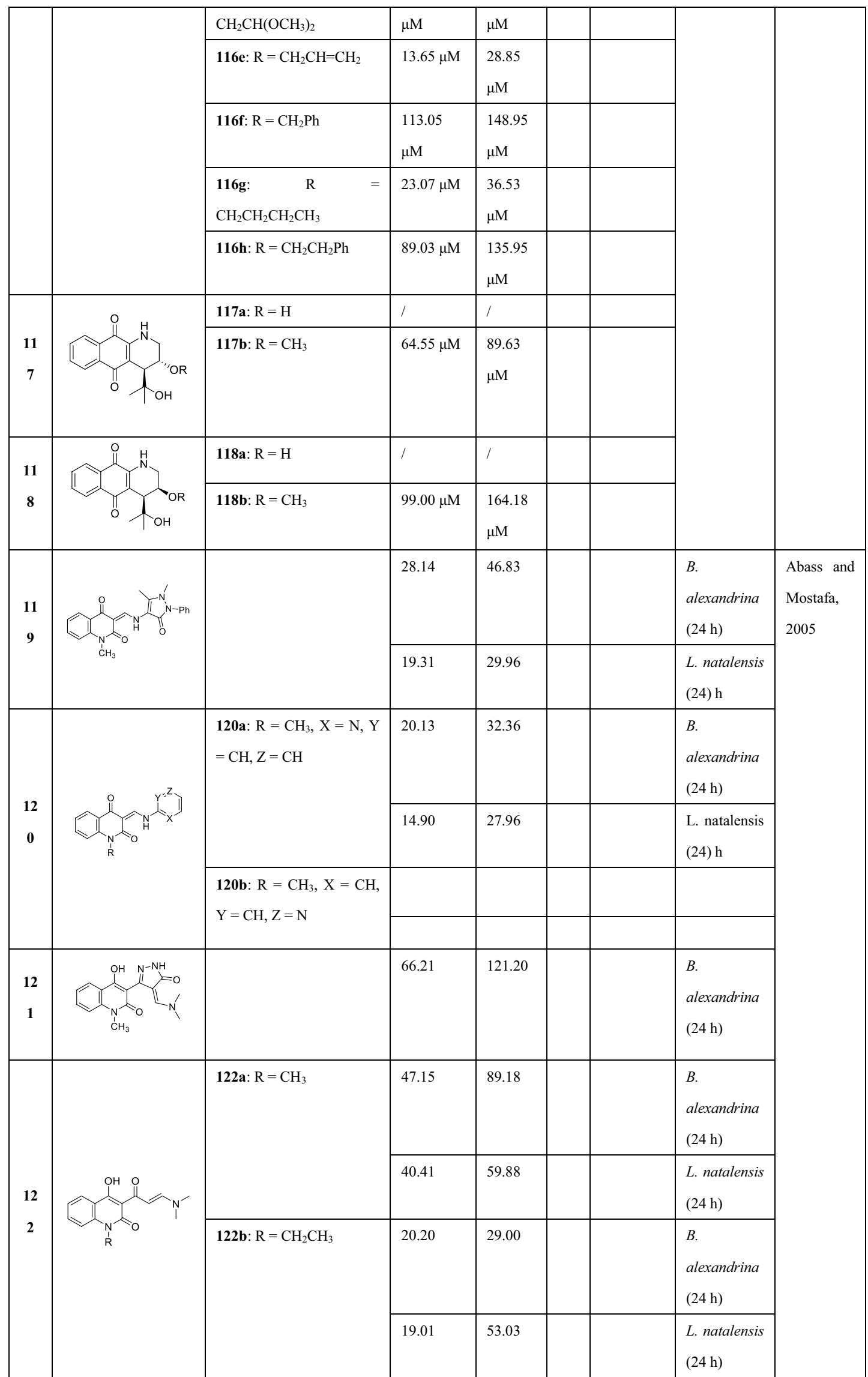


Table. 1 (continued)

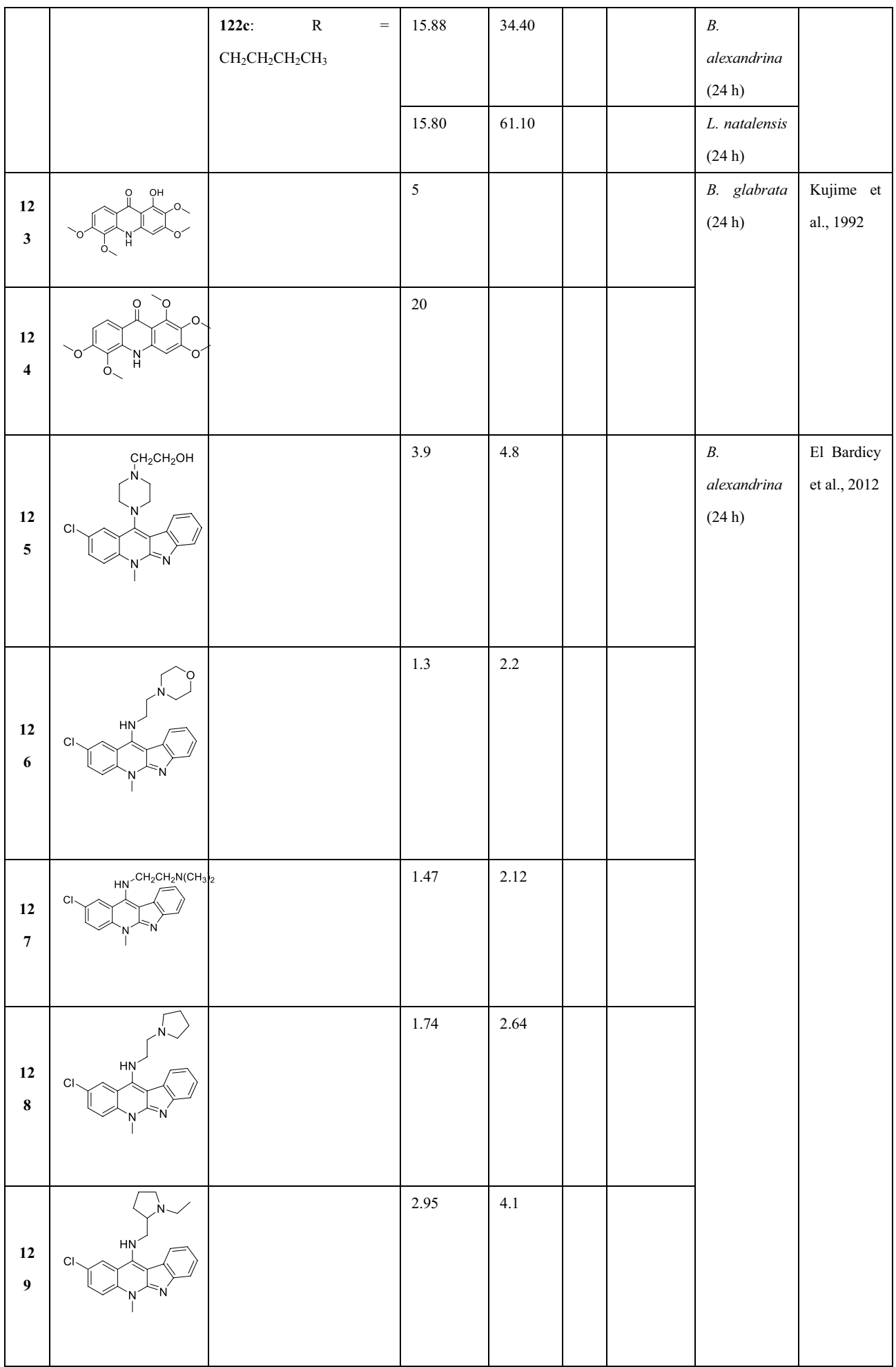

Subsequently, a suspension concentrate of niclosamide (SCN) derived from a mixture of niclosamide, alkyl polyglycosides (APG-0810), glycerol, sodium carboxymethyl cellulose, sodium benzoate, and distilled water was explored by Dai et al. (Dai et al. 2008). The size of SCN ranged from 0.28 to $19.95 \mu \mathrm{m}$, and above $90 \%$ of which were less than $10 \mu \mathrm{m}$. The content of niclosamide in SCN was about $25.44 \%(\mathrm{w} / \mathrm{w})$. The immersion experimental results showed that for adult snails, the $\mathrm{LC}_{50}$ values of $\mathrm{SCN}$ were $0.047 \mathrm{ppm}$ (24 h), $0.041 \mathrm{ppm}(48 \mathrm{~h})$, and $0.041 \mathrm{ppm}(72 \mathrm{~h})$, respectively; and for young snails, the $\mathrm{LC}_{50}$ values were $0.063 \mathrm{ppm}$ (24 h), $0.047 \mathrm{ppm}(48 \mathrm{~h})$, and $0.044 \mathrm{ppm}(72 \mathrm{~h})$, respectively. 
Table. 1 (continued)

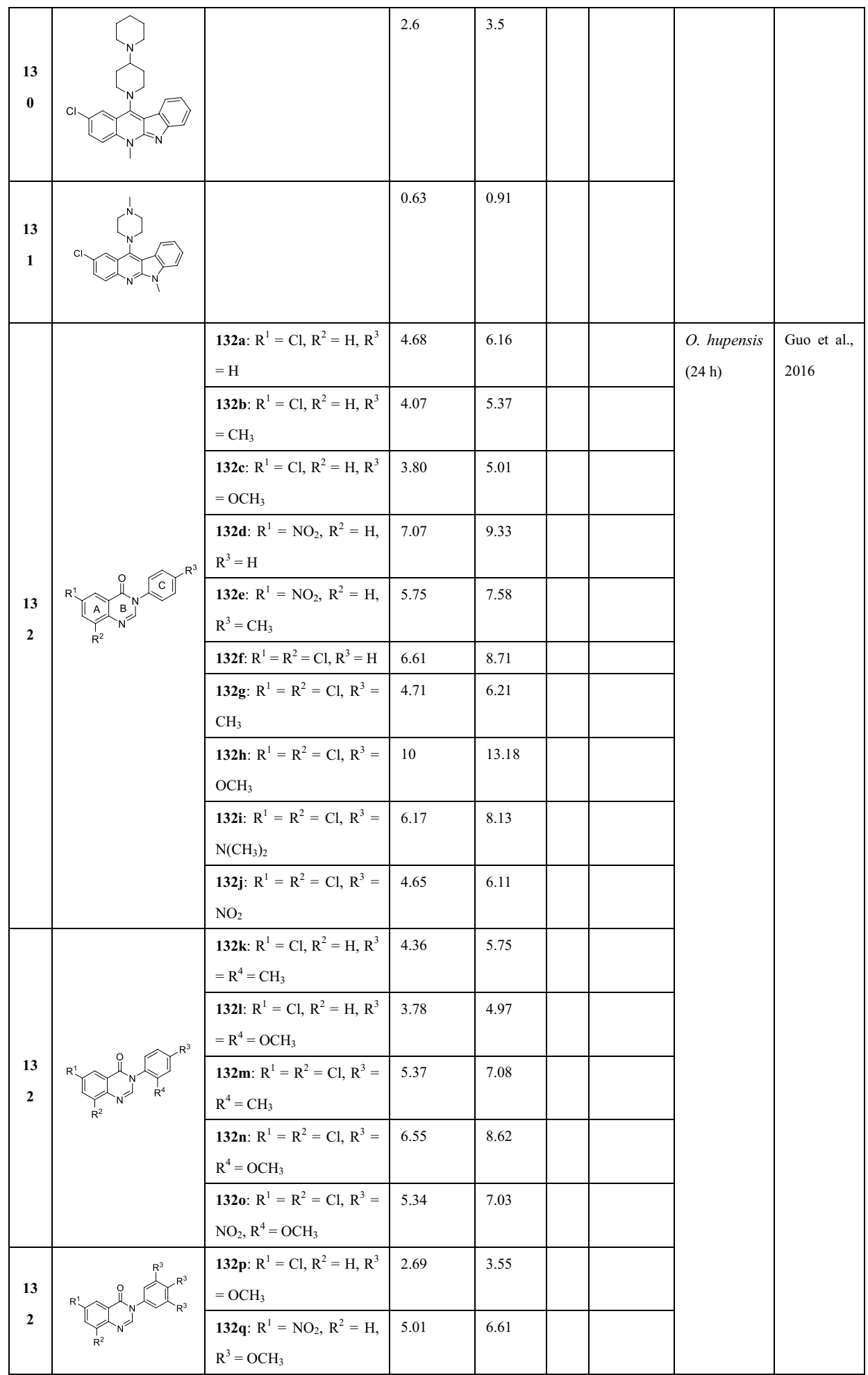

The $\mathrm{LC}_{50}$ values for adult and young snails in $24 \mathrm{~h}$ were both half that of WPN (Dai et al. 2008).

Additionally, for snail eggs, the $\mathrm{LC}_{50}$ values of $\mathrm{SCN}$ were $0.051 \mathrm{ppm}$ (24 h), $0.050 \mathrm{ppm}(48 \mathrm{~h})$, and $0.047 \mathrm{ppm}$ (72 h), respectively; and the $\mathrm{LC}_{50}$ values of WPN were $0.103 \mathrm{ppm}$ (24 h), $0.096 \mathrm{ppm}$ (48 h), and $0.087 \mathrm{ppm}$ (72 h), respectively
(Dai et al. 2008). For SCN, in the laboratory spraying experiments, the mortalities of all tested groups were $100 \%$ at the surface concentration of $0.5 \mathrm{~g} / \mathrm{m}^{2}$. However, for WPN, the mortalities of snails (O. hupensis) were $60-100 \%$, lower than that of SCN groups at the surface concentration of $1.0 \mathrm{~g} / \mathrm{m}^{2}$. In field immersion and spraying experiments, the 
Table. 1 (continued)

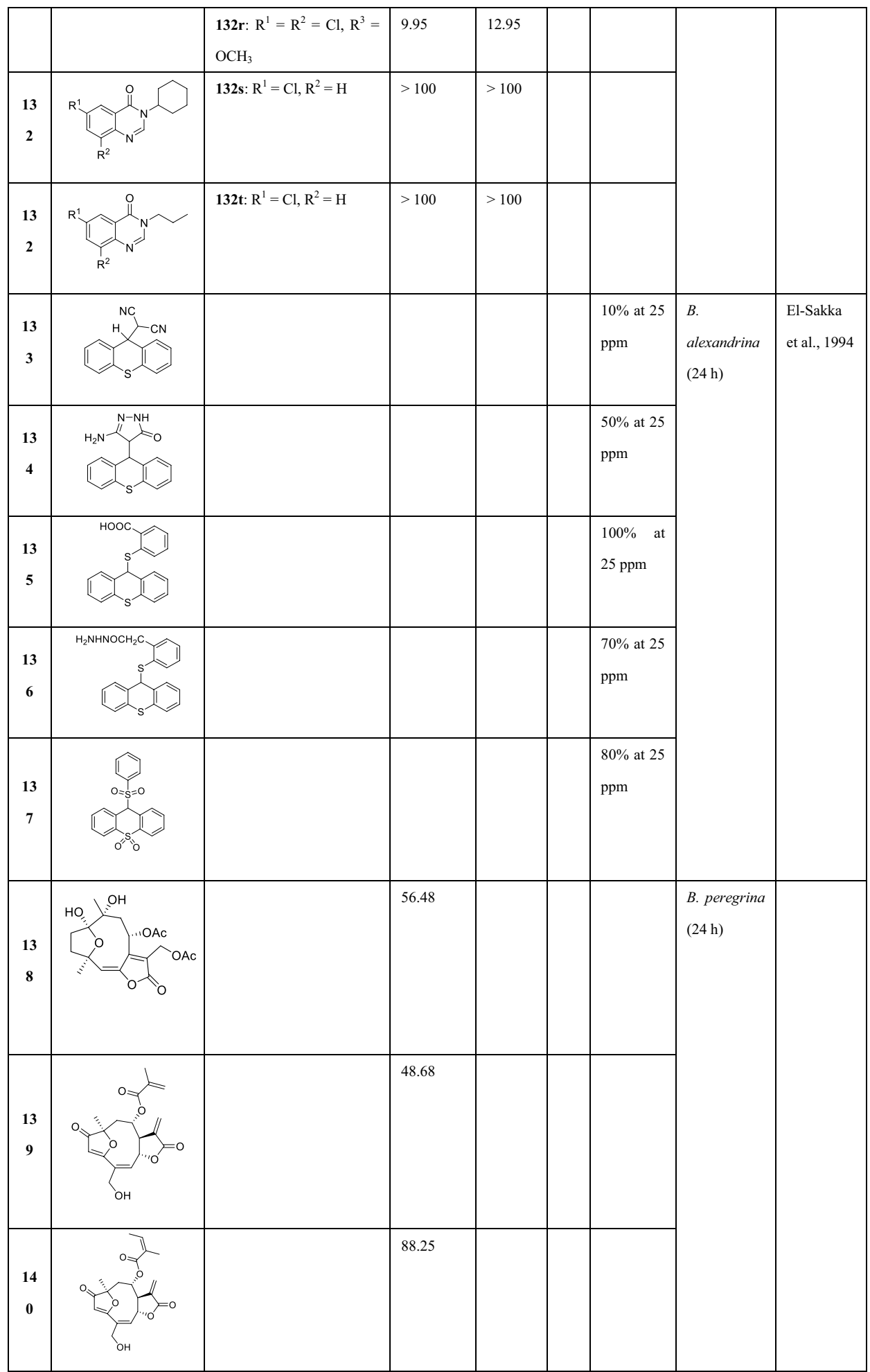

mortalities of snails for SCN were higher than that of WPN. When the snails were exposed in $0.5 \mathrm{ppm}$ of SCN for 1, 2 , and 3 days, the mortalities were $72 \%, 92 \%$, and $100 \%$, respectively, higher than that of WPN with a lethal concentration of $1.0 \mathrm{ppm}$. In field spraying test, for SCN with the concentration of $0.5 \mathrm{~g} / \mathrm{m}^{2}$, the mortalities of snails were
77 93\% (3 days), 83 99\% (7 days), and 74 99\% (15 days), respectively. However, for WPN with the concentration of $1.0 \mathrm{~g} / \mathrm{m}^{2}$, the mortalities of snails were $58 \sim 70 \%$ (3 days), $64 \sim 91 \%$ (7 days), and 68 92\% (15 days). The toxicity test showed that the acute toxicity of SCN was less than WPN. The novel formulation of SCN suspension is physically 
Table. 1 (continued)

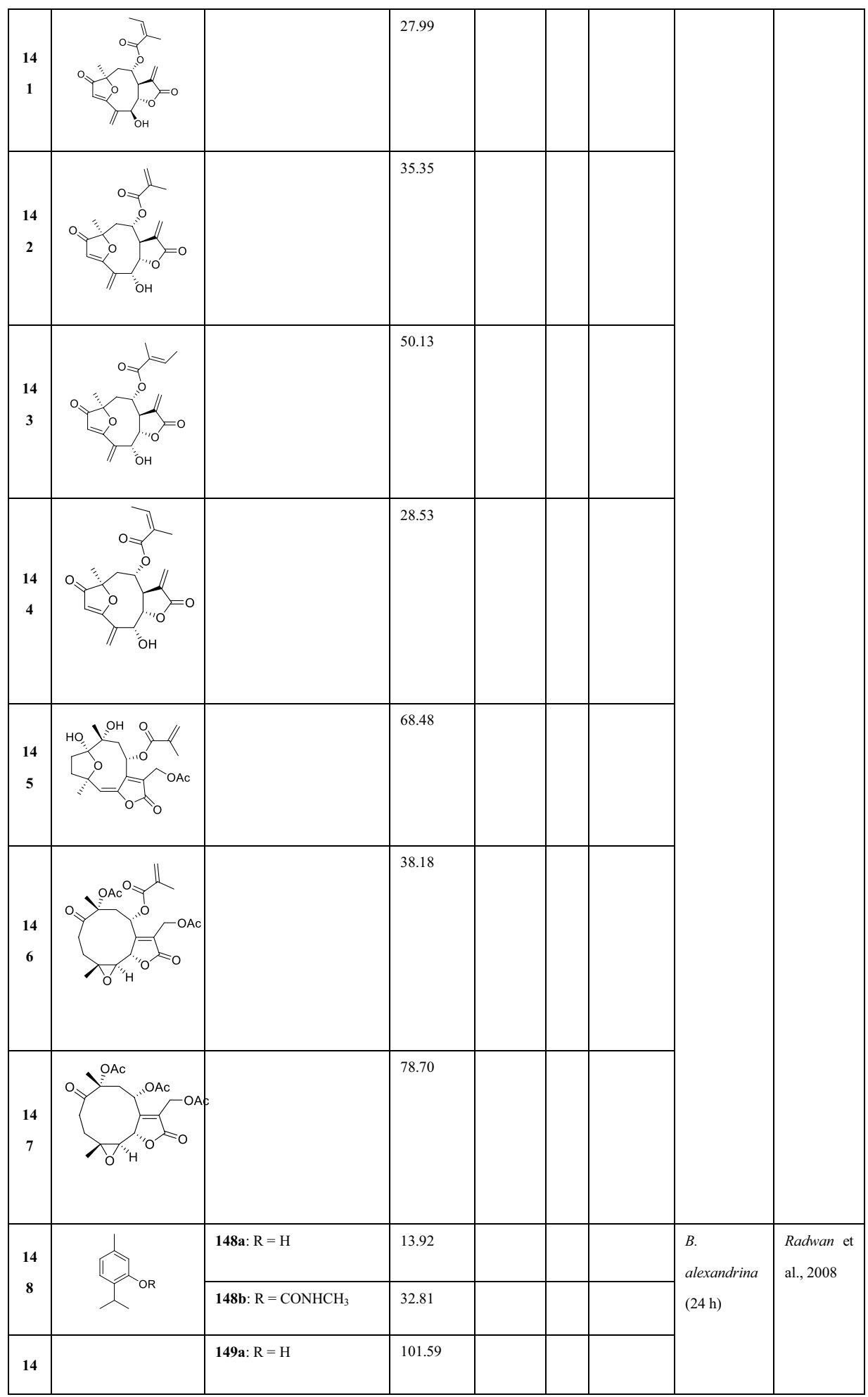

more stable, more effective, and less toxic. Therefore, it can be more useful for controlling snails in endemic areas of schistosomiasis.

In order to reduce the amount of niclosamide, decrease the toxicity and environmental issues, and provide a convenient way for practical applications, developing novel formulations of niclosamide is still a highly effective strategy for the control of snails (You et al. 2016). Huang's group explored the molluscicidal activity of $4 \%$ niclosamide ethanolamine salt powder-granula (PG) derived from niclosamide ethanolamine salt and additives (You et al. 2016). Compared with 4\% NESDP, PG showed lower 
Table. 1 (continued)

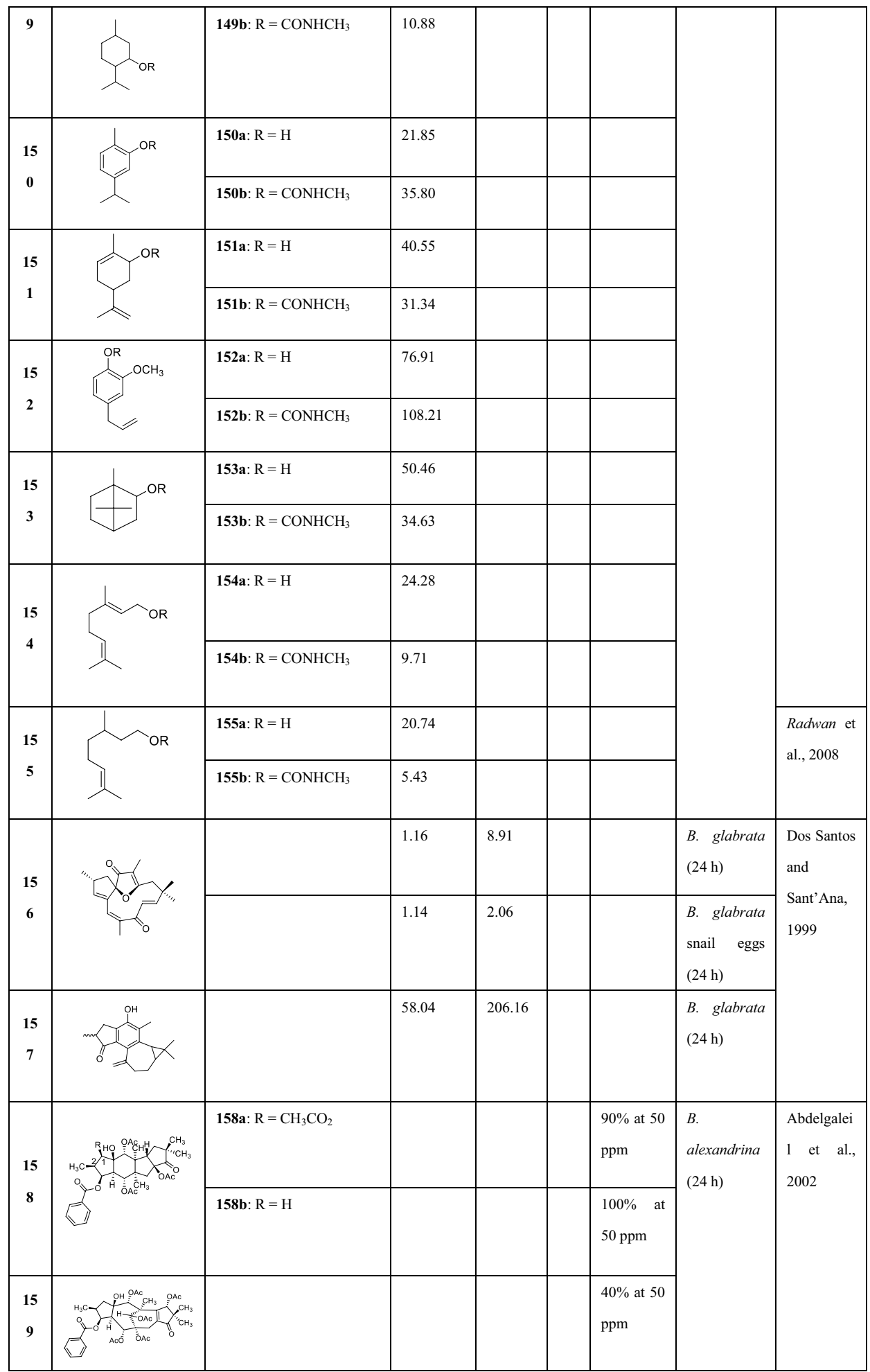

mortalities of the snails (O. hupensis) in laboratory test. However, in field experiments, for PG, the mortalities of snails were $91.71 \%$ ( 1 day) and $92.91 \%$ (3 days), which were higher than that of $4 \%$ NESDP with the mortalities of snails of $71.09 \%$ ( 1 day) and $90.11 \%$ (3 days). $4 \%$ PG has the advantages of good adsorption and penetrability, which may be more suitable for field applications.

To solve the solubility of niclosamide, emulsifiable concentrate of $25 \%$ niclosamide (ECN) was further prepared from niclosamide, organic solvents, and emulsifiers (Dai et al. 2007). In immersion experiments, the $\mathrm{LC}_{50}$ values 
Table. 1 (continued)

\begin{tabular}{|c|c|c|c|c|c|c|}
\hline \multirow{4}{*}{$\begin{array}{l}16 \\
0\end{array}$} & \multirow{4}{*}{ 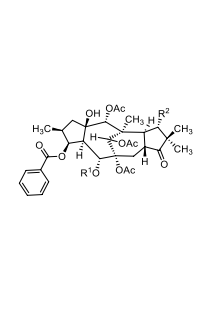 } & $\begin{array}{l}\text { 160a: } \mathrm{R}^{1}=\mathrm{CH}_{3} \mathrm{CO}, \mathrm{R}^{2}= \\
\mathrm{CH}_{3} \mathrm{CO}_{2}\end{array}$ & & $\begin{array}{l}60 \% \text { at } 50 \\
\text { ppm }\end{array}$ & & \\
\hline & & 160b: $\quad \mathrm{R}^{1}=$ & & $100 \%$ at & & \\
\hline & & $\begin{array}{l}\mathrm{CH}_{3} \mathrm{CO}_{2} \mathrm{CH}_{2} \mathrm{CO}, \quad \mathrm{R}^{2}= \\
\mathrm{CH}_{3} \mathrm{CO}_{2}\end{array}$ & & $50 \mathrm{ppm}$ & & \\
\hline & & $\begin{array}{l}\text { 160c: } \mathrm{R}^{1}=\mathrm{HOCH}_{2} \mathrm{CO}, \mathrm{R}^{2} \\
=\mathrm{H}\end{array}$ & & $\begin{array}{l}0 \% \text { at } 50 \\
\text { ppm }\end{array}$ & & \\
\hline \multirow{3}{*}{$\begin{array}{c}16 \\
1\end{array}$} & \multirow{3}{*}{ 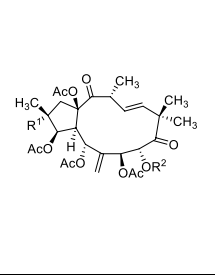 } & $\begin{array}{l}\text { 161a: } \mathrm{R}^{1}=\mathrm{CH}_{3} \mathrm{CO}_{2}, \mathrm{R}^{2}= \\
\left(\mathrm{CH}_{3}\right)_{2} \mathrm{CHCO}\end{array}$ & & $\begin{array}{l}100 \% \text { at } \\
50 \mathrm{ppm}\end{array}$ & & \\
\hline & & $\begin{array}{l}\text { 161b: } \mathrm{R}^{1}=\mathrm{CH}_{3} \mathrm{CO}_{2}, \mathrm{R}^{2}= \\
\mathrm{CH}_{3} \mathrm{CH}=\mathrm{CCH}_{3} \mathrm{CO}\end{array}$ & & $\begin{array}{l}100 \% \text { at } \\
50 \mathrm{ppm}\end{array}$ & & \\
\hline & & $\begin{array}{l}\text { 161c: } \mathrm{R}^{1}=\mathrm{H}, \mathrm{R}^{2}= \\
\left(\mathrm{CH}_{3}\right)_{2} \mathrm{CHCO}\end{array}$ & & $\begin{array}{l}60 \% \text { at } 50 \\
\text { ppm }\end{array}$ & & \\
\hline \multirow{3}{*}{$\begin{array}{l}16 \\
2\end{array}$} & \multirow{3}{*}{ 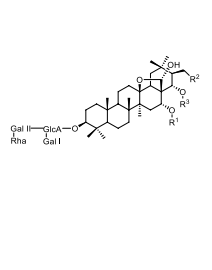 } & $\begin{array}{l}\text { 162a: } R^{1}=H, R^{2}= \\
\text { angeloyl, } R^{3}=\text { propanoyl }\end{array}$ & & $\begin{array}{l}25 \% \text { at } \\
1.5 \mathrm{ppm}\end{array}$ & \multirow{3}{*}{$\begin{array}{l}\text { B. glabrata } \\
(24 \mathrm{~h})\end{array}$} & \multirow[t]{3}{*}{$\begin{array}{l}\text { Apers et } \\
\text { al., } 2001\end{array}$} \\
\hline & & $\begin{array}{l}\text { 162b: } R^{1}=\text { acetyl, } R^{2}= \\
\text { angeloyl, } R^{3}=\text { propanoyl }\end{array}$ & & $\begin{array}{l}15 \% \text { at } \\
1.5 \mathrm{ppm}\end{array}$ & & \\
\hline & & $\begin{array}{l}\text { 162c: } \mathrm{R}^{1}=\mathrm{H}, \mathrm{R}^{2}= \\
\text { angeloyl, } \mathrm{R}^{3}=\text { angeloyl }\end{array}$ & 0.5 & $\begin{array}{l}100 \% \text { at } \\
1.5 \mathrm{ppm}\end{array}$ & & \\
\hline \multirow{4}{*}{$\begin{array}{l}16 \\
3\end{array}$} & \multirow{4}{*}{ R'O } & $\begin{array}{l}\text { 163a: } R^{1}=S^{1}, R^{2}= \\
\text { OOCCH=CHPh }\end{array}$ & 2 & & \multirow[t]{4}{*}{$\begin{array}{l}\text { B. glabrata } \\
(24 \mathrm{~h})\end{array}$} & \multirow[t]{4}{*}{$\begin{array}{l}\text { Nihei et } \\
\text { al., } 2005\end{array}$} \\
\hline & & 163b: $R^{1}=S^{1}, R^{2}=H$ & 2 & & & \\
\hline & & $\begin{array}{l}\text { 163c: } R^{1}=S^{2}, R^{2}= \\
\text { OOCCH=CHPh }\end{array}$ & 2 & & & \\
\hline & & $\begin{array}{l}\text { 163d: } R^{1}=S^{3}, R^{2}= \\
\text { OOCCH=CHPh }\end{array}$ & 8 & & & \\
\hline $\begin{array}{l}16 \\
4\end{array}$ & 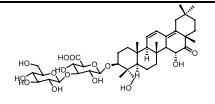 & & & $\begin{array}{l}15 \% \text { at } 30 \\
\text { ppm }\end{array}$ & \multirow{2}{*}{$\begin{array}{l}P . \\
\text { canaliculata } \\
(24 \mathrm{~h})\end{array}$} & \multirow[t]{2}{*}{$\begin{array}{l}\text { Chen et al., } \\
2020\end{array}$} \\
\hline 16 & 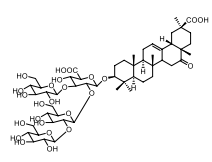 & & & $\begin{array}{l}21.25 \% \text { at } \\
30 \mathrm{ppm}\end{array}$ & & \\
\hline \multirow{3}{*}{$\begin{array}{c}16 \\
6\end{array}$} & \multirow{3}{*}{ 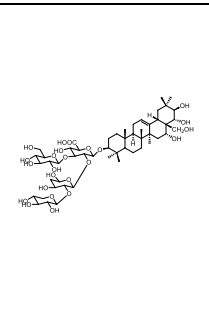 } & & 0.701 & & $\begin{array}{l}\text { O. hupensis } \\
(24 \mathrm{~h})\end{array}$ & \multirow[t]{3}{*}{$\begin{array}{l}\text { Jia et al., } \\
2019\end{array}$} \\
\hline & & & 1.975 & & $\begin{array}{l}B . \\
\text { alexandrina } \\
(24 \mathrm{~h})\end{array}$ & \\
\hline & & & 1.396 & & $\begin{array}{l}\text { B. truncates } \\
(24 \mathrm{~h})\end{array}$ & \\
\hline
\end{tabular}

of ECN were $0.041 \mathrm{ppm}(24 \mathrm{~h}), 0.032 \mathrm{ppm}(48 \mathrm{~h})$, and $0.029 \mathrm{ppm}(72 \mathrm{~h})$, respectively, significantly lower than the control groups of SCN and WPN. ECN has more chance to contact snails, resulting in better molluscicidal activities. However, the addition of solvents and emulsifiers causes higher cost of molluscicide and environmental pollution.
Three new polymeric controlled release formulations of niclosamide (B1, B2, and B3) against $B$. alexandrina were developed by Kenawy et al. (Kenawy and Rizk 2004). These polymeric formulations were prepared either by the chemical modifications of poly(glycidyl methacrylate) or by physical entrapment of the niclosamide in calcium 
Table. 1 (continued)

\begin{tabular}{|c|c|c|c|c|c|c|c|}
\hline \multirow{3}{*}{$\begin{array}{c}16 \\
7\end{array}$} & \multirow{3}{*}{ 等 } & 167a: $\mathrm{R}=\mathrm{CH}_{2} \mathrm{OH}$ & & & $\begin{array}{l}90 \% \text { at } 10 \\
\text { ppm }\end{array}$ & \multirow{4}{*}{$\begin{array}{l}B . \\
\text { alexandrina } \\
(24 \mathrm{~h})\end{array}$} & \multirow{4}{*}{$\begin{array}{l}\text { Ekabo and } \\
\text { Farnsworth } \\
, 1996\end{array}$} \\
\hline & & $167 \mathrm{~b}: \mathrm{R}=\mathrm{CH}_{3}$ & & & $\begin{array}{l}100 \% \text { at } \\
10 \mathrm{ppm}\end{array}$ & & \\
\hline & & $167 \mathrm{c}: \mathrm{R}=\mathrm{CHO}$ & & & $\begin{array}{l}0 \% \text { at } 10 \\
\mathrm{ppm}\end{array}$ & & \\
\hline $\begin{array}{l}16 \\
8\end{array}$ & 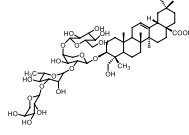 & & & & $\begin{array}{l}70 \% \text { at } 10 \\
\text { ppm }\end{array}$ & & \\
\hline 16 & & & 5.39 & & & $\begin{array}{l}\text { Monacha } \\
\text { obstructa } \\
(24 \mathrm{~h})\end{array}$ & $\begin{array}{l}\text { Alzabib et } \\
\text { al., } 2019\end{array}$ \\
\hline & & & 4.30 & & & & \\
\hline 17 & & 171a: $\mathrm{R}=\mathrm{C}_{13} \mathrm{H}_{27}$ & 3.95 & 5.86 & & O. hupensis & Yang et \\
\hline 1 & & 171b: $\mathrm{R}=\mathrm{C}_{15} \mathrm{H}_{29}$ & 1.49 & 4.74 & & $(24 \mathrm{~h})$ & al., 2008 \\
\hline & & 171c: $\mathrm{R}=\mathrm{C}_{17} \mathrm{H}_{33}$ & 11.37 & 17.75 & & & \\
\hline & & 172a: $\mathrm{R}=\mathrm{CH}_{2} \mathrm{CH}_{2} \mathrm{CH}_{3}$ & $107.2 \mu \mathrm{M}$ & $\begin{array}{r}786.6 \\
\mu \mathrm{M}\end{array}$ & & $\begin{array}{l}\text { O. hupensis } \\
\text { (48 h) }\end{array}$ & $\begin{array}{l}\text { Zhang et } \\
\text { al., } 2011\end{array}$ \\
\hline & & 172b: $\mathrm{R}=\mathrm{CH}_{2}\left(\mathrm{CH}_{2}\right)_{3} \mathrm{CH}_{3}$ & $73.1 \mu \mathrm{M}$ & $\begin{array}{l}243.6 \mu \\
M\end{array}$ & & & \\
\hline & & 172c: $\mathrm{R}=\mathrm{CH}_{2}\left(\mathrm{CH}_{2}\right)_{5} \mathrm{CH}_{3}$ & $50.9 \mu \mathrm{M}$ & $\begin{array}{l}98.2 \\
\mu \mathrm{M}\end{array}$ & & & \\
\hline 2 & & 172d: $\mathrm{R}=\mathrm{CH}_{2}\left(\mathrm{CH}_{2}\right)_{7} \mathrm{CH}_{3}$ & $43.7 \mu \mathrm{M}$ & $\begin{array}{l}135.7 \\
\mu \mathrm{M}\end{array}$ & & & \\
\hline & & 172e: $\mathrm{R}=\mathrm{CH}_{2}\left(\mathrm{CH}_{2}\right)_{8} \mathrm{CH}_{3}$ & $56.9 \mu \mathrm{M}$ & $\begin{array}{l}362.9 \\
\mu \mathrm{M}\end{array}$ & & & \\
\hline & & 172f: $\mathrm{R}=\mathrm{CH}_{2}\left(\mathrm{CH}_{2}\right)_{9} \mathrm{CH}_{3}$ & $47.2 \mu \mathrm{M}$ & $\begin{array}{l}338.7 \\
\mu \mathrm{M}\end{array}$ & & & \\
\hline & & 172g: R = Phenyl & $\begin{array}{l}0.0644 \\
\mu \mathrm{M}\end{array}$ & $\begin{array}{l}283.9 \\
\mu \mathrm{M}\end{array}$ & & & \\
\hline 17 & & 173a: $\mathrm{R}=\mathrm{CH}_{2} \mathrm{CH}_{2} \mathrm{CH}_{3}$ & $56.1 \mu \mathrm{M}$ & $\begin{array}{l}115.9 \\
\mu \mathrm{M}\end{array}$ & & & \\
\hline 3 & & 173b: $\mathrm{R}=\mathrm{CH}_{2}\left(\mathrm{CH}_{2}\right)_{3} \mathrm{CH}_{3}$ & $54.2 \mu \mathrm{M}$ & $\begin{array}{l}214.5 \\
\mu \mathrm{M}\end{array}$ & & & \\
\hline & & 173c: $\mathrm{R}=\mathrm{CH}_{2}\left(\mathrm{CH}_{2}\right)_{5} \mathrm{CH}_{3}$ & $27.5 \mu \mathrm{M}$ & 74.3 & & & \\
\hline
\end{tabular}

alginate beads. In the immersion experiments, $\mathrm{LC}_{50}$ values were $0.098 \mathrm{ppm}$ (B1), $1.09 \mathrm{ppm}$ (B2), and $0.073 \mathrm{ppm}$ (B3), respectively. For $\mathrm{B} 3$, the mortality of snails was still up to $100 \%$ after 10 days. The polymeric molluscicide (B3) showed the highest molluscicidal activity than B1 and B2.
Recently, Harras et al. reported a new polymeric molluscicide-attractant from niclosamide and L-glutamate by a controlled-release technology to control $B$. alexandrina (Kenawy et al. 2020). The alginate niclosamide-Lglutamate formulation had good affinity ability to snails. The polymeric formulations $\mathrm{B}_{3-4 \mathrm{~b}}$-L-glutamate $(0.3 \mathrm{ppm}$ 
Table. 1 (continued)

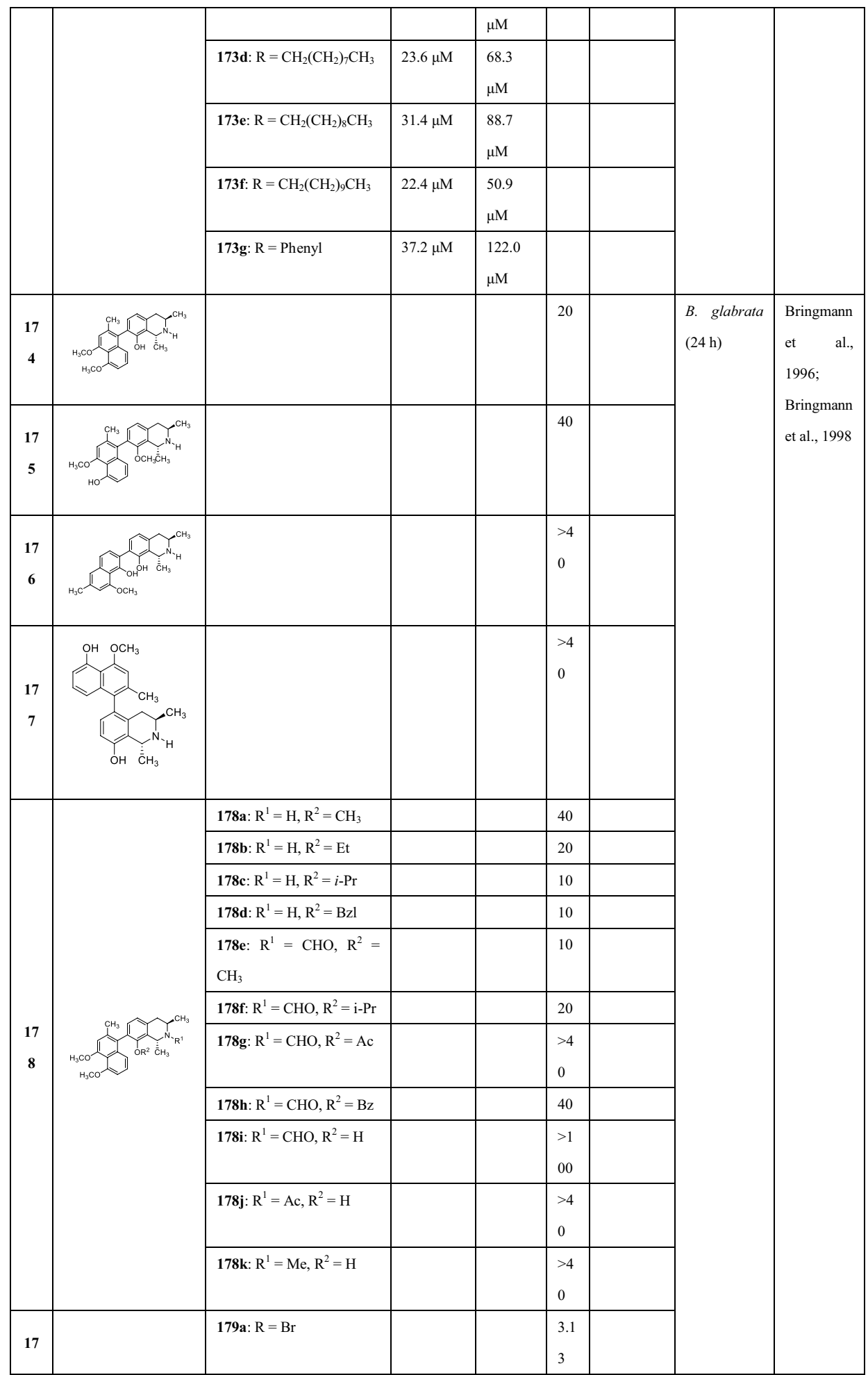

niclosamide and $75 \%$ L-glutamate) caused the aggregation of snails and showed $100 \%$ mortality after 5 days. The novel polymer-niclosamide-L-glutamate not only prolonged the validity and efficiency of the niclosamide, but also still was effective at low concentrations with increasing concentrations of the applied attractants, which could reduce the toxicity to the ecosystem.

Though excellent advances on novel niclosamide formulations have been accomplished, there is still a huge challenge to reduce the toxicity through the structure modification strategy. 
Table. 1 (continued)

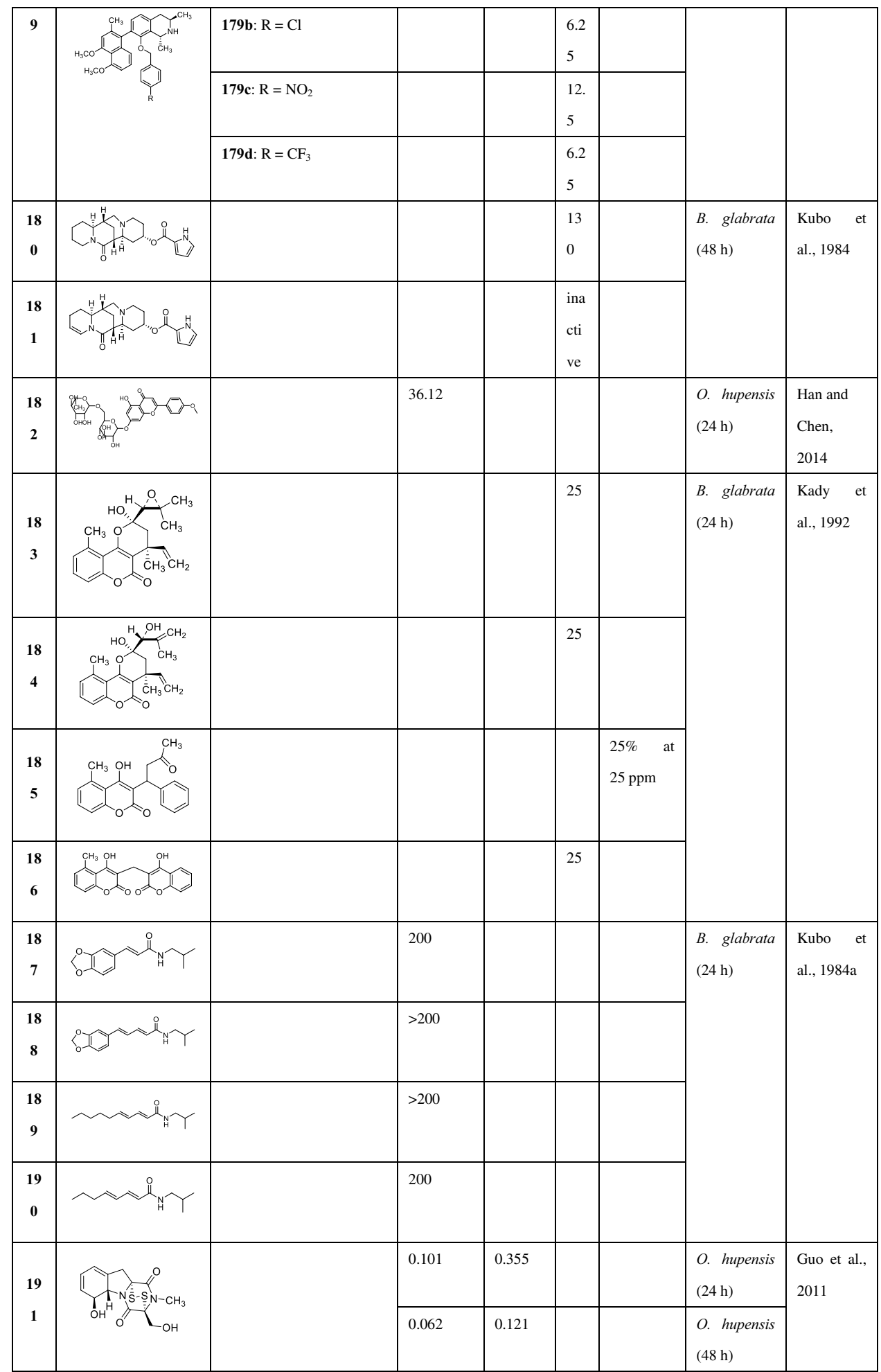

Yuan et al. reported the sodium of niclosamide sodium quinoid-2', 5-dichloro-4'-nitrosalicylanilide (13, Table 1) (LDS) obtained through the reaction of $\mathrm{NaOH}$ with niclosamide (Yuan et al. 2011). LDS showed better solubility in water and ethanol, and lower toxicity than that of niclosamide. The molluscicidal activities of 10\% LDS and 50\%
WPN were further investigated (Yuan et al. 2011). In immersion experiments, the mortalities of snails for LDS and WPN were $100 \%$ and $96.7 \%$ at $0.4 \mathrm{ppm}$ in $72 \mathrm{~h}$, respectively. In spraying experiments, the mortalities of snails for LDS and WPN were up to $100 \%$ and $97.3 \%$, respectively. In field immersion and spraying experiments, LDS and WPN 


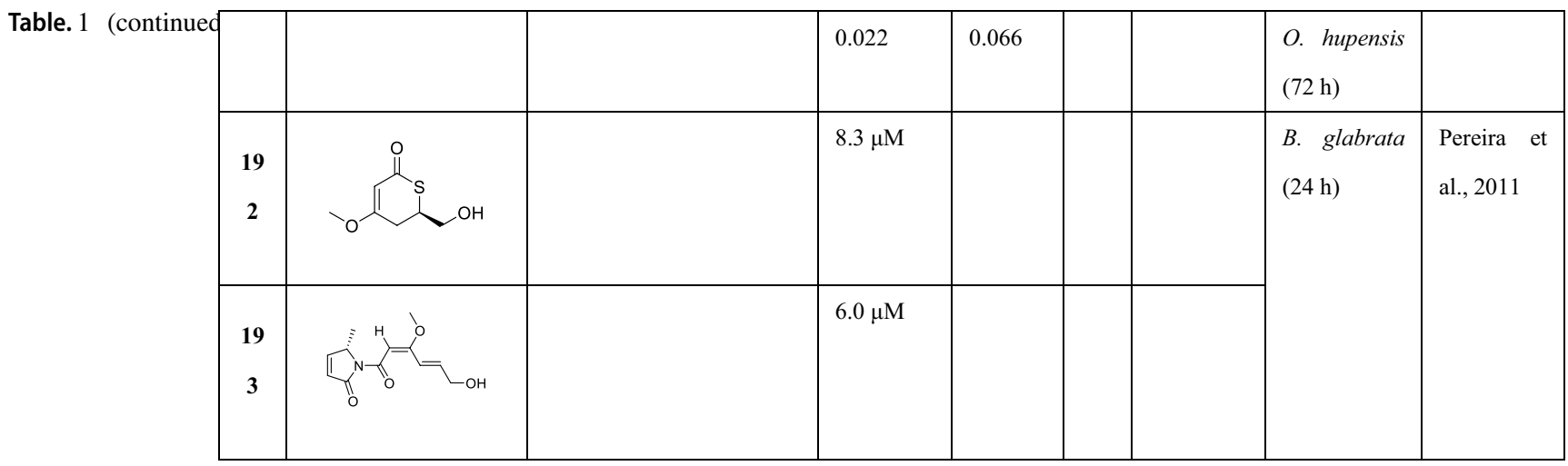

showed the similar molluscicidal activities (Xu et al. 2007; Zhang et al. 2013). In addition, LDS exhibited climbinginhibition effect against snails (O. hupensis), and the cost of LDS was also less than that of WPN (Xia et al. 2014).

In 2016, a series of salicylanilide ester derivatives was explored by Wang et al. (Wang et al. 2016). Preliminary structure-activity relationships (SARs) of the synthesized compounds showed that essential ester moieties could improve or maintain the bioactivity. The molecular structure bearing 4-methoxy phenyl ester (14, Table 1) exhibited potent molluscicidal activity among the synthetic products. In spraying experiments, the $\mathrm{LC}_{10}, \mathrm{LC}_{50}$, and $\mathrm{LC}_{90}$ values of 14 against $O$. hupensis were $0.055,0.206$, and $0.773 \mathrm{~g} /$ $\mathrm{m}^{3}$, respectively. In addition, the $\mathrm{MLC}_{50}$ value of $\mathbf{1 4}$ was $0.45 \mathrm{mmol} / \mathrm{m}^{2}$, which was superior to that of niclosamide $\left(0.51 \mathrm{mmol} / \mathrm{m}^{2}\right)$. The toxicity experiments revealed that $\mathbf{1 4}$ exhibited lower cytotoxicity against HEK293 cells compared with niclosamide. Furthermore, compound $\mathbf{1 4}$ was selected to test fish toxicity assessment using Danio rerio as model organism in ecotoxicological testes. The $\mathrm{LC}_{10}, \mathrm{LC}_{50}$, and $\mathrm{LC}_{90}$ values of $\mathbf{1 4}$ were 19.53, 30.57, and $47.85 \mathrm{ppm}$. It is notable that $\mathbf{1 4}$ exhibited no toxicity to Danio rerio at $0.25 \mathrm{pmm}$ (the $\mathrm{LC}_{50}$ of niclosamide is $0.25 \mathrm{ppm}$ ). $\mathrm{He}$ et al. also reported the molluscicidal activity of compound 14 against Biomphalaria species (He et al. 2017). The $\mathrm{LC}_{50}$ values of $\mathbf{1 4}$ against $B$. glabrata, $B$. straminea, and B. pfeifferi were $0.261,0.172$, and $0.241 \mathrm{ppm}$, respectively. However, the $\mathrm{LC}_{50}$ values of niclosamide were $0.070,0.049$, and $0.076 \mathrm{ppm}$ under the same conditions, demonstrating an approximately four fold-increased molluscicidal activity compared with that of $\mathbf{1 4}$. The acute lethal toxicity test to Danio rerio displayed that the $\mathrm{LC}_{50}(96 \mathrm{~h})$ value of $\mathbf{1 4}$ was $17.15 \mathrm{ppm}$, which is much less toxic than niclosamide (1 ppm). The above results mean that compound $\mathbf{1 4}$ shows negligible toxicity to fish and may be an environmentally friendly molluscicide candidate that surpassed the present niclosamide.

Recently, the molluscicidal activity of 4-methoxy phenyl ester (niclosamidate, 14) wettable powder (WP) in field was further investigated by Wang et al. (2017). The compound also exhibited high molluscicidal activity in the spraying experiments, and the mortality of snails was up to $81.8 \%$ at the surface concentration of $8.0 \mathrm{~g} / \mathrm{m}^{2}$. When the molluscicide was used in the immersion trials, the mortality of snails was $72.7 \%$ at $4.0 \mathrm{~g} / \mathrm{m}^{2}$. Satisfactorily, 4-methoxy phenyl ester wettable powder (WP) showed no toxicity on aquatic organisms including tadpoles, frogs, shell fish, and shrimps. But niclosamide could cause the death of fish and shellfish within $2 \mathrm{~h}$ under the same conditions. Furthermore, local fish toxic tests were carried out using crucian, cyprinoid, and chub as model fish. For 4-methoxy phenyl ester wettable powder (WP), the mortality of the tested fish was $50 \%$ at the concentration of $12.8 \mathrm{~g} / \mathrm{m}^{3}$ after $72 \mathrm{~h}$. However, for niclosamide, the mortality of snails was up to $100 \%$ at the concentration of $0.5 \mathrm{~g} / \mathrm{m}^{3}$ within $4 \mathrm{~h}$. In field experiment, niclosamide exhibited the effective molluscicidal activity at $1 \mathrm{~g} / \mathrm{m}^{3}$. Undoubtedly, 4-methoxy phenyl ester wettable powder (WP) exhibited very low toxicity to local fishes and other aquatic organisms compared with niclosamide, which can be used in aquaculture ponds.

In 1973, some substituted tetralins (15-18, Table 1) were explored as molluscicides against $B$. alexandrina snails (Nabih and Metri 1973). For compounds 15-17, the mortality rates of snails were up to $100 \%$ at $1 \mathrm{ppm}$, which were similar with the activity of niclosamide. However, the cost of these compounds was much higher than niclosamide. Nawwar et al. evaluated the molluscicidal activity of salicylamides containing piperidine moieties against $B$. alexandria snails (Nawwar et al. 1994). Compounds 19a-b (Table 1) showed the moderate molluscicidal activity. Subsequently, Nawwar et al. further evaluated the activity of salicylamides containing amino acid moieties (Nawwar et al. 1994). For compounds 20a (Table 1), the mortality of snails was up to $100 \%$ at $1 \mathrm{ppm}$.

For niclosamide and its derivatives, developing of novel formulations and rational structural modification may be an important research area. 


\section{Pyridylphenylureas}

Wang et al. developed a series of pyridylphenylurea derivatives against $B$. straminea snails through the introduction of a urea functional group into the structure of nicotinanilide (Wang et al. 2018). For compounds 21 and 22 (Table 1), the mortalities against adult snails were all up to $100 \%$ at $1.0 \mathrm{ppm}$, and the $\mathrm{LC}_{50}$ values were $0.50 \mathrm{ppm}$ and $0.51 \mathrm{ppm}$ in immersion experiments, respectively $\left(\mathrm{LC}_{90}=0.98\right.$ and $0.78 \mathrm{ppm})$. And the $\mathrm{LC}_{50}$ values against snail eggs were $0.05 \mathrm{ppm}$ and $0.09 \mathrm{ppm}$, respectively $\left(\mathrm{LC}_{90}=0.21\right.$ and $0.39 \mathrm{ppm})$. The acute lethal fish toxicity experimental results revealed that the safe dose of compound $\mathbf{2 2}$ was up to $5 \mathrm{ppm}$, which was higher than that of the effective molluscicidal dose ( $\left.\mathrm{LC}_{90}, 0.78 \mathrm{ppm}\right)$.

Furthermore, compound 21 (named PPU07) was made into the form of 25\% PPU07 sulfate WP. The field molluscicidal activity and toxicity of 25\% PPU07 sulfate WP were investigated against $O$. hupensis and local fish (Chen et al. 2019). In the spraying experiments, the mortality of snails was up to $95 \%$ at the concentration of $2.0 \mathrm{~g} / \mathrm{m}^{2}$. When snails were exposed in the $2.0 \mathrm{~g} / \mathrm{m}^{3}$ of the $25 \%$ PPU07 sulfate WP, the mortality reached $96 \%$. In the spraying and immersion trials, the WHO-recommended molluscicidal concentrations of niclosamide were $1 \mathrm{~g} / \mathrm{m}^{2}$ and $1 \mathrm{~g} / \mathrm{m}^{3}$, respectively. Additionally, 25\% PPU07 sulfate WP showed little toxicity to local fish and other aquatic organisms at the effective molluscicidal concentrations. PPU07 could be explored as promising molluscicide candidate for the control of snails.

\section{Nitro-compounds}

Abreu et al. explored the molluscicidal activity of nitroaromatic compounds against B. glabrata snails (de Abreu et al. 2001). Compounds 23-26 (Table 1) presented a significant bioactivity and the $\mathrm{LC}_{50}$ values of them (23, $\mathrm{LC}_{50}=1.8 \mathrm{ppm} ; \mathbf{2 4 a}, \mathrm{LC}_{50}=8.2 \mathrm{ppm} ; \mathbf{2 4 b}, \mathrm{LC}_{50}=0.7 \mathrm{ppm}$; $25, \mathrm{LC}_{50}=7.6 \mathrm{ppm} ; \mathbf{2 6}, \mathrm{LC}_{50}=6.4 \mathrm{ppm}$ ) were lower than $10 \mathrm{ppm}$ in $24 \mathrm{~h}$. Further electrochemical tests revealed that the presence of the electro-active $\mathrm{NO}_{2}$ group in the molecular structures was crucial for the retention of molluscicidal activity. Bond et al. also discovered the molluscicidal activity of 4-(substituted phenoxy)-3, $\beta$-dinitrostyrenes against $B$. glabrata (Bond et al. 1969). The $\mathrm{LC}_{50}$ values of compounds 27a-d (Table 1) were 8.5, 12, 8.5, and $22 \mathrm{ppm}$, respectively. It is notable that $\beta$-nitrostyrene $\mathbf{2 8}$ (Table 1 ) displayed the best activity among the tested compounds $\left(\mathrm{LC}_{50}=1.3 \mathrm{ppm}\right)$.

\section{Phenolic compounds}

Lahlou et al. prepared some phenolic compounds for the control of Bulinus truncates snails (Lahlou 2004). Compounds 29-31 (Table 1) demonstrated good molluscicidal activity $\left(\mathbf{2 9}, \mathrm{LC}_{50}=8.89 \mathrm{ppm}, \mathrm{LC}_{90}=16.82 \mathrm{ppm} ; \mathbf{3 0}\right.$, $\mathrm{LC}_{50}=3.60 \mathrm{ppm}, \mathrm{LC}_{90}=4.47 \mathrm{ppm} ; \mathbf{3 1}, \mathrm{LC}_{50}=7.71 \mathrm{ppm}$, $\left.\mathrm{LC}_{90}=14.14 \mathrm{ppm}\right)$. The compound 30 was the most effective among the phenolic products.

\section{Chalcones and its derivatives}

Adewunmi et al. tested the molluscicidal activity of a serial of chalcones and chalcone epoxides (32, Table 1) against B. glabrata snails (Adewunmi et al. 1987). An appropriate hydrophile-lipophile balance in the structure of chalocones should facilitate the improvement of activity. For example, the mortality of compound 32c against snails was up to $100 \%$ at $10 \mathrm{ppm}$ in $24 \mathrm{~h}$; however, the activity of compound 32f declined dramatically ( $37.5 \%$ mortality) when the two $\mathrm{OH}$ groups were methylated. Furthermore, the epoxidation of the chalcones also resulted in the loss of molluscicidal activity. Nawwar et al. investigated the molluscicidal activity of several 1-(hydroxy/substituted phenyl) propenones (33-35, Table 1) against B. alexandria snails (Nawwar et al. 1993). The activity of the prepared compounds was related to the conjugated system. Compounds $\mathbf{3 4 a}-\mathbf{c}$ showed the best results among the synthetic products. Especially compound 34b afforded $100 \%$ mortality of the snails at $2 \mathrm{ppm}$ in $24 \mathrm{~h}$. When the furan moiety was removed, the molluscicidal activity exhibited negative results. Barsoum et al. evaluated the molluscicidal activity of bis[1-aryl-2-propen-1-ones] (chalcones) (36a-h, Table 1) and bis[3-aryl-4,5-dihydro1H-pyrazol-1-carboxaldehydes] (37a-h, Table 1) against B. alexandrina snails (Barsoum et al. 2006). Most of the synthesized products showed moderate bioactivity at $20 \mathrm{ppm}$ in $24 \mathrm{~h}$. Compounds $\mathbf{3 7}$ exhibited superior molluscicidal activity than those of $\mathbf{3 6} \mathbf{a}-\mathbf{h}$. The substitution of $\mathrm{F}$ and $\mathrm{Cl}$ groups on pyrazol rings of substrates should enhance the molluscicidal activity.

\section{3-Hydroxy-arylpropanenitriles}

Vasconcellos et al. evaluated the molluscicidal activity of 3-hydroxy-arylpropanenitriles (38-40, Table 1) against B. glabrata snails (Vasconcellos et al. 2006). Compound 38 showed the highest activity among the tested compounds in $24 \mathrm{~h}\left(\mathbf{3 8}, \mathrm{LC}_{50}=6.64 \mathrm{ppm}, \mathrm{LC}_{90}=9.23 \mathrm{ppm} ; \mathbf{3 9}\right.$, $\mathrm{LC}_{50}=7.30 \mathrm{ppm}, \mathrm{LC}_{90}=10.64 \mathrm{ppm} ; \mathbf{4 0}, \mathrm{LC}_{50}=17.71 \mathrm{ppm}$, $\mathrm{LC}_{90}=22.7 \mathrm{ppm}$ ). Compound $\mathbf{4 0}$ displayed the lowest toxicity to snails, which could be attributed to the different hydrophilic-lipophilic ability of the naphthalene nucleus. The detailed structural-activity relationships of the 
3-hydroxy-arylpropanenitriles should be further explored in future experiments.

\section{Five-membered heterocylces}

Kanawade et al. explored novel thiophenedicarboxamide and dicyanothiopheneacetamide derivatives for the control of Indoplanorbis exustus snails (Kanawade et al. 2011). The $\mathrm{LC}_{50}$ values of compounds 41a and 42a (Table 1) were 0.6043 and $0.6511 \mathrm{ppm}$ in immersion experiments, respectively. Fadda et al. evaluated the molluscicidal activity of thiophene, thiadiazole, and pyrazole derivatives (43-45, Table 1) against $B$. alexandrina snails (Fadda et al. 2009). Thiadiazole derivatives $(\mathbf{4 4 a}-\mathbf{c})$ possessed higher activity than that of thiophene derivatives (43a-d) apparently because of the strong electron-donating effect of the thiadiazole ring. For example, compounds $\mathbf{4 4 b}$ and $\mathbf{4 4 c}$ demonstrated the best activity with the $\mathrm{LC}_{50}$ value of $5.5 \mathrm{ppm}$ and $6 \mathrm{ppm}$, respectively. The surface of snails demonstrated the effusion of the gelatinous materials, which could cause the toxic effect on the cell membranes and resulted in hemolysis and subsequent death (Fadda et al. 2009).

El Shehry et al. carried out the molluscicidal activity of 3-((2,4-dichlorophenoxy)methyl)-1,2,4-triazolo(thiadiazoles and thiadiazines) (46-50, Table 1) against $B$. alexandrina snails (El Shehry et al. 2010a, b). Compounds $\mathbf{4 6}$ and $\mathbf{4 7}$ displayed $100 \%$ mortality of snails at $10 \mathrm{ppm}$ in $24 \mathrm{~h}$. However, the other compounds (48-50) showed moderate to low activity against snails. Abdelrazek et al. developed a serial of pyrazole derivatives for the control of $B$. alexandrina snails. Products 51a-d (Table 1) exhibited good molluscicidal activity in immersion experiments $\left(\mathrm{LC}_{50}=11-13 \mathrm{ppm}\right.$; $\mathrm{LC}_{90} \geq 14 \mathrm{ppm}$ ) (Abdelrazek et al. 2006a, b).

\section{Six-membered $N$-heterocyles}

Some novel functionally substituted pyridines and pyridazines (52-54, Table 1) were prepared and evaluated against $B$. alexandrina snails in $24 \mathrm{~h}\left(\mathrm{LC}_{100}=6-15 \mathrm{ppm}\right)$ (Abdelrazek and Fathy 2005). The electron-withdrawing groups on the aromatic ring (Ar group) of the tested compounds $(\mathbf{5 2 b}, \mathbf{5 3 b}, \mathbf{5 4 b})$ showed higher molluscicidal activity in $24 \mathrm{~h}$.

El-Bayouki et al. discovered the molluscicidal activity of some thiazolo[5,4-d]pyrimidines (55, Table 1) against $B$. alexandrina snails (El-Bayouki and Basyouni 1988). Compounds 55a and 55i showed more effective activity, and the mortalities of snails were up to $100 \%$ at $25 \mathrm{ppm}$ in $24 \mathrm{~h}$. Bakhotmah et al. evaluated the molluscicidal activity of the phosphorus compounds bearing an amino pyrimidine-substituted pyrazolo[3,4-d]pyrimidine moiety against $B$. alexandrina snails (Bakhotmah 2019). For compounds 56 and
57 (Table 1), the mortalities of snails were all only $30 \%$ at $50 \mathrm{ppm}$ in immersion experiments in $24 \mathrm{~h}$.

Abdelrazek et al. developed new cinnoline derivatives and evaluated the molluscicidal activity to $B$. alexandrina snails (Abdelrazek et al. 2006a). Compounds 58-59 (Table 1) possessed good effects on the snails $\left(\mathbf{5 8 a}, \mathrm{LC}_{50}=8 \mathrm{ppm}\right.$, $\mathrm{LC}_{90}=11 \mathrm{ppm} ; \mathbf{5 8 b}, \mathrm{LC}_{50}=7 \mathrm{ppm}, \mathrm{LC}_{90}=15 \mathrm{ppm}$; 58c, $\mathrm{LC}_{50}=7 \mathrm{ppm}, \mathrm{LC}_{90}=9 \mathrm{ppm} ; \mathbf{5 9 a}, \mathrm{LC}_{50}=8 \mathrm{ppm}$, $\mathrm{LC}_{90}=13 \mathrm{ppm} ; \mathbf{5 9 b}, \mathrm{LC}_{50}=9 \mathrm{ppm}, \mathrm{LC}_{90}>15 \mathrm{ppm} ; \mathbf{5 9 c}$, $\mathrm{LC}_{50}=7 \mathrm{ppm}, \mathrm{LC}_{90}=9 \mathrm{ppm}$ ). Compounds 58c and 59c showed superior activities mainly attributed to the 4-chlorophenyl group. Ali et al. explored the molluscicidal activity of phosphorus-containing 3-hydrazino-1,2,4-triazines against B. alexandrina snails (Ali et al. 2008). However, the tested products $(\mathbf{6 0}-\mathbf{6 2}$, Table 1$)$ showed low activity at $50 \mathrm{ppm}$ in $24 \mathrm{~h}$. Abdel-Rahman et al. investigated a serial of 6-methyl5-styryl-1,2,4-triazin-3-thiol derivatives for the control of $B$. alexandrina snails (Abdel-Rahman et al. 2003). Compounds 63, 64, and 66 (Table 1) had the moderate molluscicidal activity at $50 \mathrm{ppm}$ in immersion experiments in $24 \mathrm{~h}$. The $p$-dimethylamino, 1, 2, 4-dichloro phenyl, and $\beta$-naphthol moieties should play an essential role against snails. The molluscicidal activity of phthalazin-one $\mathbf{6 7}$ (Table 1) was also investigated for the control of $B$. alexandrina snails, and the $\mathrm{LC}_{50}$ value was $9 \mathrm{ppm}$ in $24 \mathrm{~h}\left(\mathbf{6 7}, \mathrm{LC}_{90}=13 \mathrm{ppm}\right)$ (Abdelrazek et al. 2006a, b).

\section{Pyrane derivatives}

Souza et al. evaluated the molluscicidal activity of the 5,6-dimethyl-dihydro-pyran-2,4-dione and 6-substituted analogous (de Souza et al. 2004). Compounds 68-70 (Table 1) showed moderate activity against $B$. glabrata egg masses. The substitution of the propenyl or phenyl group in C-6 position of dihydro-pyran-2,4-diones could improve the molluscicidal activity. Flavones $\mathbf{7 1}$ and $\mathbf{7 2}$ (Table 1) were developed for the control of Bulinus truncatus snails, and the $\mathrm{LC}_{50}$ values of them were $5.47 \mathrm{ppm}$ and $8.91 \mathrm{ppm}$ in $24 \mathrm{~h}$, respectively (71, $\left.\mathrm{LC}_{90}=9 \mathrm{ppm} ; \mathbf{7 2}, \mathrm{LC}_{90}=17 \mathrm{ppm}\right)$ (Lahlou 2004).

Abdelrazek et al. synthesized and evaluated the molluscicidal activity of new chromene and pyrano[2,3-c]pyrazole derivatives (73-77, Table 1) against $B$. alexandrina snails (Abdelrazek et al. 2007). Compounds 75 and $\mathbf{7 6 b}$ afforded the most effective activity. The decoration of dimethyl substituents in the cyclohexanone ring and the fused pyran ring might improve molluscicidal bioactivity. For $\mathbf{7 6 b}$, the $\mathrm{NH}$ of the indolyl moiety afforded the chelation effect, resulted in the enhancement of molluscicidal activity. The pyrane derivatives 78-82 (Table 1) were prepared for the control of $B$. alexandrina snails. All synthesized products exhibited generally moderate molluscicidal activity in immersion experiments. The most effective of them are 79a, 80a, 82a, 
and $\mathbf{8 2 b}\left(\mathrm{LC}_{50}<10 \mathrm{ppm}\right)$. It seemed that pyranopyrazole derivative 79a should be a promising leading compound after appropriate modifications in future (Abdelrazek et al. 2006a, b).

Abdelrazek et al. discovered the molluscicidal activity of 5-oxo-5,6,7,8-tetrahydro- $4 \mathrm{H}$-chromene derivatives against B. alexandrina snails (Abdelrazek et al. 2004). The $\mathrm{LC}_{50}$ values of compounds 83a and 84a (Table 1) were $5 \mathrm{ppm}$ $(17.61 \mathrm{nM})$ and $8 \mathrm{ppm}(28.17 \mathrm{nM})$ in $24 \mathrm{~h}$, respectively, which are still far inferior to niclosamide $\left(\mathrm{LC}_{100}=1 \mathrm{ppm}\right)$. New pyrano derivative 85a (Table 1) exhibited the highest activity against $B$. alexandrina snails within the pyrano[2,3c]pyrazole series (Abdelrazek et al. 2006a), which should be modified and considered in future research.

\section{Benzofuran derivatives}

El Shehry et al. screened the molluscicidal activity of some pyrazole, isoxazole, pyridine, pyrimidine, 1,4-thiazine, and 1,3,4-thiadiazine derivatives incorporating benzofuran moiety (86-89, Table 1 ) against $B$. alexandrina snails (El Shehry et al. 2010a, b). Compound $\mathbf{8 6}$ showed the highest molluscicidal activity and the mortality of snails was up to $100 \%$ at $10 \mathrm{ppm}$ in immersion experiments in $24 \mathrm{~h}$. Compounds 87-89 displayed good to moderate activity among the tested products. Giri et al. found that 1-aryl-1(substituted benzofur-2-yl)-2-benzylcarbinols (90, Table 1) and 1-aryl-1-(substituted benzofur-2-yl)-2-phenylethylenes (91, Table 1) exhibited moderate activity against Lymnea acuminata snails (Giri and Mishra 1984a, b). Hassan et al. developed furo-salicylanilides for the control of B. alexandrina snails (Hassan et al. 2006). Compounds $\mathbf{9 2 b}$ and 92d showed lower molar concentration than that of Bayluscicide. However, cyclization of compound $\mathbf{9 2 b}$ to afford compound 93b (Table 1) resulted in the decrease of molluscicidal activity.

\section{Benzimidazole derivatives}

Nofal et al. developed the molluscicidal activity of benzimidazole derivatives for the control of $B$. alexandrine snails (Nofal et al. 2002). Compounds 94 and 95 (Table 1) exhibited moderate molluscicidal activity at $24 \mathrm{~h}$ in immersion experiments. However, the polycyclic benzimidazole derivatives 96-97 showed worse molluscicidal activity.

\section{Coumarin derivatives}

Giri et al. developed the molluscicidal activity of 3-substituted 4-hydroxycoumarin derivatives for the control of Lymnaea acuminata snails (Giri and Mishra 1984a, b). The compounds 98 and 99 (Table 1) showed the good molluscicidal activity at $5 \mathrm{ppm}$, and the mortalities of snails were $58.33 \%$ and $68.33 \%$ in $24 \mathrm{~h}$, respectively. Schönberg et al. explored the molluscicidal activity of furocoumarins against Biomphalaria alexandrina snails (Schönberg and Latif 1954). Compounds 100 and 101 (Table 1) killed 100\% and $69 \%$ of the snails at $5 \mathrm{ppm}$ in immersion experiments in $24 \mathrm{~h}$, respectively.

\section{Lapachol and its derivatives}

Lapachol (102, Table 1) is a notable natural product from Tecoma heptaphylla (Vell Mart.) (Bignoniaceae). Lapachol showed poor molluscicidal activity against snails in earlier reports (Marston et al. 1984). Santos et al. re-investigated the activity of lapachol and its derivatives against the $B$. glabrata snails (dos Santos et al. 2000). In immersion experiments, the tested compounds 102-105 (Table 1) showed a significant molluscicidal activity against adult snails in $24 \mathrm{~h}$ (compound 102, $\mathrm{LC}_{50}=2.57 \mathrm{ppm}, \mathrm{LC}_{90}=6.18 \mathrm{ppm}$; compound 103, $\mathrm{LC}_{50}=1.53 \mathrm{ppm}, \mathrm{LC}_{90}=4.30 \mathrm{ppm}$; compound 104, $\mathrm{LC}_{50}=4.02 \mathrm{ppm}, \mathrm{LC}_{90}=7.15 \mathrm{ppm}$; and compound 105, $\left.\mathrm{LC}_{50}=5.19 \mathrm{ppm}, \mathrm{LC}_{90}=18.46 \mathrm{ppm}\right)$. Additionally, compound 104 exhibited the highest molluscicidal activity against snail eggs $\left(\mathrm{LC}_{50}=0.014 \mathrm{ppm}, \mathrm{LC}_{90}=0.070 \mathrm{ppm}\right)$ in immersion experiments in $24 \mathrm{~h}$. Furthermore, the activity of 2-hydroxy-3-substituted-aminomethyl derivatives was also investigated against snail eggs. However, the activity of them was lower than compounds 102-105. Santos et al. developed a soluble potassium salt of lapachol 106 (Table 1) from the reaction of lapachol with $\mathrm{KOH}$ (dos Santos et al. 2001). The $\mathrm{LC}_{50}$ values of $\mathbf{1 0 6}$ against $B$. glabrata adult snails and eggs reached 2.70 and $1.43 \mathrm{ppm}$ after $24 \mathrm{~h}$ in the immersion experiments, respectively. Silva et al. developed a series of amino and hydrogenated lapachol derivatives (107-108, Table 1) for the control of B. glabrata snails (Silva et al. 2005). Compounds 107a, 107b, 108a, 108c, 108d, 108e, and $108 \mathrm{~h}$ showed medium toxicity against snails $\left(23.8<\mathrm{LC}_{50}<89.0 \mathrm{mmol} / \mathrm{L}\right)$ in immersion experiments. However, $\mathbf{1 0 7}$, $108 \mathrm{~b}$, and $\mathbf{1 0 8 f}$ were less active $\left(\mathrm{LC}_{50}>200 \mathrm{mmol} / \mathrm{L}\right)$. It is notable that compounds $\mathbf{1 0 8} \mathbf{g}$ and 109 (Table 1) exhibited significant molluscicidal activity and the $\mathrm{LC}_{50}$ values were 13.8 and $7.6 \mathrm{mmol} / \mathrm{L}$ in $24 \mathrm{~h}$, respectively.

The molluscicidal activity of the potassium salt of isolapachol (110, Table 1) was explored for the control of B. glabrata (Lima et al. 2002a, b). Compound $\mathbf{1 1 0}$ exhibited good activity against adult snails $\left(24 \mathrm{~h} \mathrm{LC}_{50} 3.05 \mathrm{ppm}\right.$, $\left.\mathrm{LC}_{90} 4.71 \mathrm{ppm}\right)$ and snail eggs ( $24 \mathrm{~h} \mathrm{LC}_{50} 0.33 \mathrm{ppm}, \mathrm{LC}_{90}$ $0.48 \mathrm{ppm}$ ) in immersion experiments. However, 110 showed high toxicity against fishes (T. nilotica) $\left(24 \mathrm{~h} \mathrm{LC}_{50} 2.05 \mathrm{ppm}\right.$, $\left.\mathrm{LC}_{90} 2.43 \mathrm{ppm}\right)$ and planktonic crustaceae (A. salina) $(24 \mathrm{~h}$ $\mathrm{LC}_{50} 2.05 \mathrm{ppm}, \mathrm{LC}_{90} 2.43 \mathrm{ppm}$ ). Lima et al. evaluated the molluscicidal activity of lapachol and its derivatives and analogues for the control of $B$. glabrata snails (Lima et al. 
2002a). The $\mathrm{LC}_{50}$ values of compounds 111a and 111c (Table 1) against adult snails were 0.98 and $1.66 \mathrm{ppm}$ in $24 \mathrm{~h}$, respectively. Compounds 111b, 111d, 111e, and 112 (Table 1) also displayed the moderate molluscicidal activity, with $\mathrm{LC}_{50}$ values in the range of 3.82-7.72 ppm in $24 \mathrm{~h}$.

Ribeiro et al. prepared some naphthoquinones and evaluated the molluscicidal activity of compounds 113-114 (Table 1) for the control of B. glabrata snails (Ribeiro et al. 2009). The $\mathrm{LC}_{50}$ values of the tested products ranged from 0.475 to $3.049 \mathrm{ppm}$ in $24 \mathrm{~h}$. Camara et al. evaluated the molluscicidal activity of naphthoquinone derivatives for the control of B. glabrata snails (Camara et al. 2008). The presence of a bromine group in compound 115c (Table 1) resulted in almost 15 -fold molluscicidal activity compared to compound 115a. However, these synthesized products exhibited obvious toxicity to the brine shrimp A. salina (Camara et al. 2008). Barbosa et al. developed new 2-aminoalkyl substituted anthraquinones from norlapachol for the control of $B$. glabrata snails (Barbosa et al. 2005). Compounds 116a-h (Table 1) displayed moderate activity. The increase of polarity of molecules can lead to the decrease of bioactivity (for 116b and 116c), which exhibits a similar trend to that of amino lapachol derivatives reported by Silva's group (Silva et al. 2005). Therefore, compound $\mathbf{1 1 6} \mathbf{g}$ displays the best molluscicidal activity among the tested products. However, the molluscicidal activity was sharply diminished when the aminoalkyl substituted compounds were converted into the cyclic molecules 117 and 118 (Table 1).

The above findings confirm the importance of lapachol and its derivatives as promising molluscicides.

\section{Quinoline derivatives}

Serials of novel enaminones derived from 4-hydroxyquinolinones (119-122, Table 1) were prepared by Abass' group (Abass and Mostafa 2005). Part of these products exhibited good molluscicidal activity of against $B$. alexandrina and Lymnaea natalensis snails $\left(\mathrm{LC}_{50}<20 \mathrm{ppm}\right)$. For compounds 122a-c, the structure-activity relationship showed that the molluscicidal activity increased with the improvement of the lipophilicity of the molecules. In addition, the acute toxicity of the tested molluscicides against D. magna was also explored, and the experimental results revealed that the candidate compounds showed $0 \%$ mortality at $\mathrm{LC}_{50}$ concentrations after $48 \mathrm{~h}$. Kujime et al. evaluated the molluscicidal activity of acridone alkaloids against B. glabrata snails (Kujime et al. 1992). Compounds $\mathbf{1 2 3}$ and 124 (Table 1) showed moderate bioactivity in $24 \mathrm{~h}$. El Bardicy et al. evaluated the molluscicidal activity of aminoalkylamino substituted neo- and norneocryptolepine derivatives (125-131, Table 1) against B. alexandrina snails (El Bardicy et al. 2012). The $\mathrm{LC}_{50}$ values of the tested products were $0.63-3.9 \mathrm{ppm}$ in $24 \mathrm{~h}$.
Our group discovered the molluscicidal activity of 3-substituted quinazolinone derivatives $\mathbf{1 3 2}$ (Table 1) through a scaffold hopping approach using a pseudo-ring based on the intramolecular hydrogen bond formation (Guo et al. 2016). Most of the tested compounds showed good molluscicidal activity against $O$. hupensis with the $\mathrm{LC}_{50}$ values ranged from 2.69 to $10 \mathrm{ppm}$. The preliminary structure-activity relationship exhibited that the aromatic rings are essential for $\mathrm{C}$ section and the electron-donating groups on the $\mathrm{C}$ ring can promote the molluscicidal activity.

\section{Thiaxanthene derivatives}

El-Sakka et al. evaluated thiaxanthene derivatives (133-137, Table 1) against B. alexandrina snails (El-Sakka et al. 1994). Compounds 136- $\mathbf{1 3 7}$ showed considerable activity, and $\mathbf{1 3 5}$ possessed the highest mortality in $24 \mathrm{~h}$ at $25 \mathrm{ppm}$.

\section{Development of plant molluscicides}

Chemical molluscicides are still the most convenient option for the control of snails and have been used successfully in practical applications (Perrett and Whitfield 1996). However, the registered chemical molluscicides (such as niclosamide, copper sulfate, and sodium pentachlorophenate) are still rare due to high cost, toxicity to non-target organisms, high residual risk, and relatively complicated synthesis process (Brackenbury and Appleton 1998). Some plant molluscicides are considered inexpensive and environmental friendly to the health of aquatic organisms and mammals, and some pure compounds have also been isolated from plant and proven to have molluscicidal activity against snails. Development of natural plant molluscicides may be a suitable alternative for snail control (Zhu et al. 2010).

\section{Sesquiterpene lactones}

Borkosky et al. evaluated the molluscicidal activity of sesquiterpene lactones from the tribe Vernonieae, family Asteraceae (Borkosky et al. 2009). The tested products 138-147 (Table 1) demonstrated moderate molluscicidal activity against $B$. peregrina snails. The $\mathrm{LC}_{50}$ values ranged from 27.99 to $88.25 \mathrm{ppm}$ in $24 \mathrm{~h}$.

\section{Monoterpenoids}

Radwan et al. evaluated the molluscicidal activity of monoterpenoid derivatives (148-155, Table 1) for the control of B. alexandrina snails (Radwan et al. 2008). Most of the compounds showed molluscicidal activity; especially compound $\mathbf{1 5 5 b}$ was the most effective among the tested compounds $\left(\mathrm{LC}_{50}=5.43 \mathrm{ppm}\right)$. Furthermore, mixing 
compounds 154a and 155a with piperonyl butoxide (PBO) afforded the $\mathrm{LC}_{50}$ values of 2.69 and $2.72 \mathrm{ppm}$ in $24 \mathrm{~h}$, respectively.

\section{Diterpenoids}

Dos Santos et al. discovered the molluscicidal activity of diterpenoids (156-157, Table 1) isolated from Jatropha elliptica (Pohl) Muell. Arg (dos Santos and Sant'Ana 1999). Compared with product 157, products 156 showed molluscicidal with the $\mathrm{LC}_{50}$ values of $1.16 \mathrm{ppm}$ (adult snails) and $1.14 \mathrm{ppm}$ (snail eggs) in $24 \mathrm{~h}$. However, product 157 was not active against $B$. glabrata snails at a concentration of $100 \mathrm{ppm}$. Abdelgaleil et al. extracted some diterpenes (158-161, Table 1) from Euphorbia paralias $\mathrm{L}$ and evaluated the molluscicidal activity against $B$. alexandrina snails (Abdelgaleil et al. 2002). Most of the obtained products showed moderate molluscicidal activity except product 160c. Notably, among the isolated products, product $\mathbf{1 5 8 b}$ showed the best activity with the $100 \%$ mortality at $15 \mathrm{ppm}$ in $24 \mathrm{~h}$. The preliminary structure-activity relationship of the tested products exhibited that paraliane diterpenes $(\mathbf{1 5 8 a}-\mathbf{b})$ showed higher activity than segetane diterpenes $(159,160 a-c)$ to snails. For paraliane diterpenes, the acetoxyl group at $\mathrm{C} 1$ in compound $\mathbf{1 5 8 a}$ was unfavorable for the improvement of activity. In the case of $160 \mathbf{a}-\mathbf{c}$, the present of acetoxy group $\left(\mathrm{R}^{2}\right)$ facilitated the molluscicidal activities, which were similar to $161 \mathrm{a}-\mathbf{c}$.

\section{Triterpenoid saponins}

Molluscicidal activity of triterpenoid saponins from Maesa lanceolata was assessed by Apers et al. (2001). Among the tested products, compound 162c (Table 1) showed the best activity against $B$. glabrata snails and the $\mathrm{LC}_{50}$ value was $0.5 \mathrm{ppm}$ in $24 \mathrm{~h}$. Novel triterpene saponins (163a-d, Table 1) were isolated from African medicinal plant, Pachyelasma tessmannii for the control of B. glabrata snails (Nihei et al. 2005). The $\mathrm{LC}_{50}$ values of 163a-d were 2, 2, 2, and 8 ppm within $24 \mathrm{~h}$, respectively. Triterpenoid saponins 164 and 165 (Table 1) were extracted from the roots of Pueraria peduncularis (Chen et al. 2020). The two products 164 and 165 displayed moderate molluscicidal activity with the mortalities of $15 \%$ and $21.25 \%$ at $30 \mathrm{ppm}$ in $24 \mathrm{~h}$, respectively. A pentacyclic triterpenoid saponin 166 (Table 1) was exacted from the seed pomace of Camellia oleifere, which was widely cultivated in South China (Jia et al. 2019). Product 166 has been named as tea-seed distilled saponin (TDS) and been registered as Luo-Wei by the Ministry of Agriculture (MoA) of China. Compound 166 showed significant molluscicidal activity against $O$. hupensis, $B$. alexandrina, and Bulinus truncates, and the $\mathrm{LC}_{50}$ values were $0.701 \mathrm{ppm}$,
$1.975 \mathrm{ppm}$, and $1.396 \mathrm{ppm}$ in $24 \mathrm{~h}$, respectively. In addition, TDS showed moderate toxicity to Japanese quail and shrimp, and high toxicity to zebrafish $\left(96 \mathrm{~h} \mathrm{LC}_{50}=0.15 \mathrm{ppm}\right.$ ). For all that, TDS may be a promising candidate molluscicide of plant origin to eliminate snails in high-risk areas. Ekabo et al. tested the novel saponins (167-168, Table 1) extracted from Serjania salzmanniana for the control of B. alexandrina snails (Ekabo and Farnsworth 1996). For products (167a-b, 168), the mortalities of snails were $70-100 \%$ at $10 \mathrm{ppm}$ in $24 \mathrm{~h}$. However, product 167c exhibited no activity at $10 \mathrm{ppm}$.

\section{Cardiac glycosides}

The two molluscicidal active cardiac glycosides, cerberin 169 and neriifolin 170 (Table 1), were isolated from the stems of Adenium obesum (Alzabib et al. 2019). Products 169 and 170 had significant molluscicidal activity against Monacha obstructa snails with $\mathrm{LC}_{50}$ values of 5.39 and $4.30 \mathrm{ppm}$ in $24 \mathrm{~h}$, respectively.

\section{Ginkgolic acids}

Yang et al. evaluated the molluscicidal activity of ginkgolic acids (171a-c, Table 1), isolated from Ginko sarcotesta against $O$. hupensis (Yang et al. 2008). Product 171b showed the best molluscicidal activity among the isolated components. The $\mathrm{LC}_{50}$ value of $\mathbf{1 7 1 b}$ was $1.49 \mathrm{ppm}$ against $O$. hupensis. Zhang et al. tested the molluscicidal activity of ginkgolic acid derivatives against $O$. hupensis (Zhang et al. 2011). Compounds 172 and 173 (Table 1) displayed moderate bioactivity in immersion experiments. The preliminary structure activity relationship showed that the $E$-isomers (173) were superior to $Z$-isomers (172). Prolonging the chain lengths of alkenyl on aromatic cycle structures could enhance molluscicidal activity.

\section{Alkaloids}

Bringmann et al. evaluated the molluscicidal activity of naphthylisoquinoline alkaloids (174-179, Table 1) from Triphyophyllum and Ancistrocladus species (Bringmann et al. 1996, 1998). Most of the tested products demonstrated moderate activity against $B$. glabrata snails. Compounds $178 \mathbf{c}-\mathbf{e}$ showed the best activity and the $\mathrm{LC}_{100}$ values of them were $10 \mathrm{ppm}$ in $24 \mathrm{~h}$. However, compounds 176, 177, and $178 \mathbf{~ g - k}$ exhibited no significant activities. It is notable that the $\mathrm{LC}_{100}$ values of products $\mathbf{1 7 9} \mathbf{a}-\mathbf{d}$ were $3.13-12.5 \mathrm{ppm}$. Kubo et al. tested the molluscicidal activity of quinolizine alkaloids from the African medicinal plant Calpurnia aurea (Papilionaceae) against B. glabratus snails (Kubo et al. 1984a, b). For compound 180 (Table 1), the snail mortality was up to $100 \%$ mortality at $130 \mathrm{ppm}$ in $48 \mathrm{~h}$. 
However, the similar compound $\mathbf{1 8 1}$ (Table 1) did not kill snails even at $1000 \mathrm{ppm}$.

\section{Acacetin derivatives}

Buddleja lindleyana is an important traditional medicinal plant in China. Acacetin-7-rutinoside 182 (Table 1) was isolated from the $n$-butanol fraction of fresh $B$. lindleyana leaves by Han et al. The structure of $\mathbf{1 8 2}$ was characterized through NMR (Han and Chen 2014). Product 182 had moderate molluscicidal activity against $O$. hupensis with the $\mathrm{LC}_{50}$ value of $36.12 \mathrm{ppm}$ in $24 \mathrm{~h}$.

\section{Coumarins}

Kady et al. evaluated the molluscicidal activity of coumarins from Ethulia conyzoides (183-185, Table 1) and of dicumarol (186, Table 1) (Kady et al. 1992). Compounds 183, 184, and 186 possessed good molluscicidal activity against $B$. glabrata snails. Especially, the $\mathrm{LC}_{90}$ values of compound 183 were 19-23.5 ppm for all age-group snails in $24 \mathrm{~h}$. In addition, compound $\mathbf{1 8 3}$ could kill cercariae of schistosome at $25 \mathrm{ppm}$. However, compound $\mathbf{1 8 5}$ exhibited poor molluscicidal activity.

\section{Isobutylamides}

Kubo et al. evaluated the molluscicidal activity of isobutylamides isolated from the East African medicinal tree Fagara macrophylla (Rutaceae) (Kubo et al. 1984a). Compounds 187 and 190 (Table 1) showed considerable activity against $B$. glabratus snails. However, compounds $\mathbf{1 8 8}$ and 189 (Table 1) were ineffective in killing snails.

\section{Gliotoxin and others}

Guo et al. found the gliotoxin (191, Table 1) by extracting the rhizospheric strain from Phytolacca acinosa Roxb (Guo et al. 2011). The structure of 191 was confirmed by NMR and LC-MS. The $\mathrm{LC}_{50}$ values of $\mathbf{1 9 1}$ against $O$. hupensis were $0.101 \mathrm{ppm}(24 \mathrm{~h}), 0.062 \mathrm{ppm}(48 \mathrm{~h})$, and $0.022 \mathrm{ppm}(72 \mathrm{~h})$, respectively. Pereira et al. isolated compounds 192 and 193 (Table 1) from the assemblage of Palmyra Atoll Cyanobacteria to kill B. glabrata (Pereira et al. 2011). The $\mathrm{LC}_{50}$ values of 192 and 193 were $8.3 \mu \mathrm{M}$ and $6.0 \mu \mathrm{M}$ in $24 \mathrm{~h}$, respectively. In addition, the equimolar mixture of 192 and $\mathbf{1 9 3}$ afforded the higher activity with the $\mathrm{LC}_{50}$ value of $5.0 \mu \mathrm{M}$ in $24 \mathrm{~h}$.

In addition, several plants, such as Phytolacca dodecandra (Endod) (Karunamoorthi et al. 2008), Solanum xanthocarpum (Changbunjong et al. 2010), Annona squamosa
(Tiwari 2012), Thuja orientalis (Singh and Singh 2009), Stryphnodendron polyphyllum (Vinaud et al. 2008), Calotropis procera and Adenium arabicum (Al-Sarar et al. 2012), Eomecon chionantha (Peng et al. 2011), Balanites aegyptiaca (Brimer et al. 2007), Meryta denhamii (Hassan et al. 2010), Anagallis arvensis (Abdel-Gawad et al. 2000), Dioscorea zingiberensis (Liu et al. 2001), Balanites aegyptiaca (Molla et al. 2013), Eupatorium adenophorum (Zou et al. 2009) and so on, have already been identified as useful to control the intermediate hosts of trematodes. However, the chemical structure of these molluscicidal active ingredients from the plant should be elucidated in future work.

\section{Mechanism research}

Recently, some achievements on the discovery of novel chemical and natural molluscicides have been accomplished to control snails (Chen et al. 2019; de PaulaAndrade et al. 2019). For the development of new molluscicides, exploration of the mechanism is important for the enhancement of molluscicidal activity and the reduction in non-target toxicity (Huang 2019a, b). Most of the molluscicides can induce the injury of snail soft tissues and influence the activity of key enzymes, leading to the changes of a serial of physiological and biochemical characteristics, and finally resulting in the death of snails (Nie et al. 2009).

\section{Effect of molluscicides on snail soft tissues}

He et al. (2017) investigated the ultrastructural features and changes of the soft tissues of $B$. glabrata snails including tentacle, mantle, plantaris, and hepatopancreas after treatment with salicylanilidate and niclosamide through the scanning electron microscopy (SEM) and transmission electron microscope (TEM) (He et al. 2017). The SEM photographs showed that salicylanilidate and niclosamide caused swelling of the tentacle and deformation of cilia in the mantle. Salicylanilidate mainly damaged the rough endoplasmic reticulum, and resulted in the aggregation of heterochromatin and vacuolization of the mitochondria, as well as polymorphic changes of the nucleus. In contrast, niclosamide primarily caused polymorphic alterations of the nucleus, substantial heterochromatin aggregation, and partially destructed the rough endoplasmic reticulum. Li et al. also observed the ultra-structural changes of cerebral the ganglion of $O$. hupensis after treatment with niclosamide ( $\mathrm{Li}$ et al. 1997). The mitochondrion of neural fibers, neuroglial cells, neurons, and neuropil displayed denaturation and necrosis, and the content of glycogen in neurons was also reduced obviously. Tan et al. found 
that the muscular fold of snail became smoother and the muscular structure was destroyed by the combination of arecoline with sodium pentachlorophenate or niclosamide (Tan et al. 2001).

LDS or WPN could reduce the number of mitochondria of $O$. hupensis and damage the mitochondrial cristae (Xiong et al. 2016). The gathered heterochromatin was also polarized. These molluscicides might further decrease the number of ribosomes in the rough endoplasmic reticulums (rERs), and loose the myofilaments in muscle cells. At the same time, cytoplasm in some liver cells was gathered together. The above phenomena indicated that molluscicides could damage cell structures and organelles, and inhibit the movement ability of sails, which might cause harmful effects on the liver and energy metabolism. SEM photographs showed that the 1-(4-chlorophenyl)-3(pyridin-3-yl)urea and 1-(4-bromophenyl)-3-(pyridin-3-yl) urea could also destroy the tentacles and sub-tegumental tissue (Wang et al. 2018). The tegumental surface of the mantle and the columellar muscle of foot plantaris exhibited turgidity, blebbing, exfoliation, erosion, and chap, and the cilia became tangled, adherent, and peeled off from the issue.

The influence of the seed of Camellia sinensis $(L) O$. Kuntze on the tegument of soft tissues of $O$. hupensis was explored by SEM (Wang et al. 1997). The tegument of head of snails exhibited serious damage and deformity after treatment with the drug. The snail foot was also thickened and wrinkled, and infiltrated with numerous cells. The drug destroyed the tissue of the mantle and visceral sac at liver of snails.

The fluid extracted from Nerium indicum leaves caused swelling on the surface of head, foot, and mantle soft tissues of $O$. hupensis (Chen et al. 2001). The rupture and exfoliation of parts of the tissue surface were also observed. The numbers, size, depth, and distribution of the holes on the tissue surface changed obviously (Chen et al. 2001). Additionally, the surface of the visceral sac of liver swelled, and became rough, accompanied with the increasing clearance and irregular holes.

Ke et al. (1999) discovered the damage in exterior tissues of the head, foot, and liver of $O$. hupensis after treatment with water extract from Pterocarya stenoptera leaves by SEM. The head, foot muscle, and mantle of the snail swelled, which were destroyed seriously and the lip exhibited serious deformity after treatment with the $1.0 \%$ water extract. The drugs could also cause numerous holes in visceral sac liver.

The observation of Eomecon chionantha alkaloids (ECA) on the genital system of O. hupensis was carried out by Sun et al. (2005). ECA could destroy the genital system of snails. The oocyte of O. hupensis was obviously atrophied, and the spermatogonium exhibited pyknosis.
Based on the above observation, some molluscicides could damage the head, foot, mantle, liver, visceral sac, gonad, and neural fiber of snails, which influenced the activity, energy metabolism, detoxification, genital, and nervous systems leading to the death of snails.

\section{Effect of molluscicides on key enzyme activity of snails}

Enzymes are essential to snails and are often being explored to evaluate the interactions between drugs and target organisms. The change of enzyme activity often means the changes of the physiology or pathology in the snail body $(\mathrm{Pu}$ et al. 2008). Generally, nitric oxide synthase (NOS) and cholinesterase (CHE) are involved in neural signal transduction; malondialdehyde (MDA) reflects the level of lipid peroxidation; superoxide dismutase (SOD) and peroxidase (POD) are involved in anti-oxidative stress; alanine aminotransferase (ALT), aspartate aminotransferase (AST), glutamic-pyruvic transaminase (GPT), and glutamic-oxaloacetic transaminase (GOT) reflect liver function. They are all related to stress responses of snails. Other enzymes such as glycogen, succinate dehydrogenase (SDH), malic dehydrogenase (MDH), acid phosphatase (ACP), alkaline phosphatase (AKP), cytochrome c oxidase (CCO), glucose-6-phosphatase (G-6Pase), and lactate dehydrogenase (LDH) are involved in the process of carbohydrate metabolism.

Mello-Silva et al. (2010) evaluated the carbohydrate metabolism alterations in B. glabrata snails exposed to Euphorbia splendens var. hislopii latex. Latex could cause the decrease of the glycogen levels in the carbohydrate deposits. The latex of Euphorbia splendens should be used as a promising natural molluscicide.

A suspension concentrate of niclosamide could reduce the enzyme activity of NOS, CCO, CHE, SDH, and LDH in $O$. hupensis ( $\mathrm{Li}$ et al. 2006). The neurotransmitter and energy systems were interrupted by niclosamide, which resulted in the disorder of the physiological functions and caused the death of snails. Salicylanilidate was further selected to investigate the effects on some important enzymes of snails (He et al. 2017). The activities of AKP, ACP, LDH, NOS, and AChE showed that salicylanilidate could inhibit the LDH, NOS, and AChE activities and increase the AKP activity. Salicylanilidate could also reduce the transcriptional levels of ACP, NOS, and SOD in the hepatopancreas. However, the 1-(4-bromophenyl)-3-(pyridin-3-yl)urea improved ACP and NOS activities and exhibited no obvious alterations in the activities of AChE and SOD (Wang et al. 2018).

Exposure to LDS and WPN molluscicide inhibited carbohydrate metabolism (CCO, SDH, G-6-Pase), while the activity of LDH increased in muscle tissue (Xiong et al. 2016). These changes of carbohydrate metabolism patterns could decrease energy supply and lead to lactic acid accumulation. 
The activity of CHE in the pellicle of snails was inhibited after treatment by LDS or WPN in $24 \mathrm{~h}$, which was significantly lower than in the control group. In addition, the levels of NOS, ALT, and SOD were found to be increased at early stages, which might lead to a stress response of snails to the molluscicides and finally cause fatal damage in liver and nervous system. According to the experimental results, LDS and WPN showed similar effects although LDS-treated snails exhibited more serious damages in the liver and a stronger inhibition activity of enzymes related with aerobic respiration and stress response. However, the molecular and enzymatic level mechanism researches are worth of further considerable explorations to develop novel molluscicides in future.

Activities of $\mathrm{CCO}$ and AChE enzymes were reduced significantly after treatment by META-Li (Zhu et al. 2007), while the activities of LDH and NOS increased significantly. However, the activity change of SDH was not obvious. The energy metabolism and nerve transmission should be destroyed by META-Li.

Han et al. (2012) explored the enzyme histochemical profiles of CCO, LDH, SDH, NOS, and CHE in the soft tissues of $O$. hupensis using the active ingredient of Buddleia lindleyana (AIBL) as a potent and safe plant molluscicide. The results displayed that AIBL could impair the activities of $\mathrm{CCO}, \mathrm{LDH}, \mathrm{SDH}, \mathrm{NOS}$, and $\mathrm{CHE}$, which disturbed the transfer of neurotransmitter and energy supply in snails and ultimately destroyed their various physiological functions, resulting in the death of snails.

It was found that the enzymatic activities of $\mathrm{LDH}$, $\mathrm{SDH}, \mathrm{AChE}, \mathrm{CCO}$, and NOS in the muscle fibers, ganglia, mouth, liver, pharyngeal cavity, and tegumentary membrane decreased after being treated with HL (Zhang et al. 2007). The mechanism of HL is similar to that of niclosamide.

The glycogen content of snail livers decreased obviously being treated by SAN, which indicated that the energy metabolism was suppressed (Sun et al. 2011). However, the level of MDA did not change significantly. Therefore, SAN has no significant effect on the lipid peroxidation of snails. Furthermore, the activities of ALT, AST, ACP, AKP, and SOD were increased significantly, which demonstrated that the liver cells, cytomembranes, and organelles of snails were damaged after treatment with SAN. The changes of above enzymes meant that SAN could destroy the metabolism of liver, hepatotoxicity, and hepatic disorder.

Chen et al. (2007) explored the molluscicidal mechanism of the extract of Ginkgo biloba sarcotesta by benzinum (EGSB) against $O$. hupensis. EGSB could significantly inhibit ChE, ALT, ALP, and MDH activities both in the cephalopodium and liver. However, EGSB could not affect LDH activity in the cephalopodium and the liver. The molluscicidal action of EGSB was also different to that of niclosamide in some extent.
Mahmoud et al. (2011) investigated the mechanism of Datura stramonium and Sesbania sesban against B. alexandrina snails. The glucose and total protein concentrations in hemolymph of snails were decreased after being treated with these plants. However, the activities of the enzymes AST, ALT, ACP, and AKP were increased significantly in hemolymph, which indicated that the liver of snails was damaged by molluscicides. The crude extracts of the Calendula micrantha officinalis and Ammimajus could also inhibit the activities of ALT and AST, reduce the total protein content, and promote the lipid contents in the hemolymph of B. alexandrina or Bulinus truncatus snails (Rawi et al. 1996).

The water extracts of Pterocarya stenoptera and Rumex japonicus could increase the activity of GPT and GOT, which damaged the liver functions of $O$. hupensis (Ke et al. 2000). Molluscicide B002 could reduce the activity of NOS in the center ganglions, heart wall, testes, ovary, and pharyngeal cavity of snails. However, niclosamide had no effect on the NOS of snails (Hang et al. 2001).

Esterase isozyme (EST) plays an important role in the body's antidotal pathways. Chen et al. (2008) investigated the influences of stemona alkaloids on esterase isozyme (EST) activity and glycogen content of $O$. hupensis. The activity of esterase isozymes firstly increased, and then decreased until the activation was almost lost. The content of glycogen also decreased in the experimental group. The changes of EST activity revealed that the snails have certain detoxification effect at low concentration of the molluscicide. However, the detoxification systems were destroyed completely with the time extended or at higher concentration of stemona alkaloids. The extracts of Alternanthera philoxeroides, Nerium Indicum Mill, Pterocarya stenoptera DC, and Rumex japonicum Houtt all exhibited similar effect on the activity of EST in O. hupensis snails (Feng et al. 2008; Wang et al. 2006).

The MDA content of the liver in snails increased significantly after being treated with the water extract of Arisaema erubescens schott (Ke et al. 2006). However, the activities of POD and SOD in the treated liver were decreased significantly. The water extract of Arisaema erubescens schott could cause an oxidative damage and an obvious decrease of antioxidant ability of $O$. hupensis liver, which might play an key role in reducing the detoxification ability of liver and, finally, resulting in the death of snails.

\section{Conclusion and future outlook}

There is no doubt that molluscicides may play an important role in controlling of schistosomiasis transmission in endemic countries (Zhang et al. 2019). Novel ideal molluscicides should fulfill the following requirements (Fenwick 1987; Cao and Wang 2008; Huang 2019a, b): (1) high 
toxicity to snails at low concentration; (2) very low acute and chronic toxicity to non-target organisms; (3) without adverse effect in the food chain; (4) good stability for 18 months or more; (5) acceptable cost and safe for users. For chemical molluscicides, on the one hand, developing new chemical entities (NCE) is a promising strategy for snail controlling through rational drug design on molecular levels. Therefore, hunting appropriate drug targets of snail is crucial for pharmacologists. Exploring the effect of the present molluscicides on key enzyme activity of snails should provide important references for the development of novel enzyme inhibitors to kill snails (Xiong et al. 2018). On the other hand, developing new formulations based on the available molluscicides (such as niclosamide, LDS, PPU07) is an alternative method in practical applications. Novel formulations such as WPN, NESDP, SCN, and ECN have also been successfully utilized in endemic areas (Xu et al. 2005). However, the stability of these new formulations should be screened, and simultaneously require more field experiments in future works.

Plant molluscicides attract more and more attention. However, some unfavorable factors should not be overlooked (Li et al. 2002): (1) low content of the active ingredients resulted in low molluscicidal activity; (2) regional limitations for some specific molluscicidal plants; (3) relative complicated extraction process resulting in high cost; (4) environmental pollution because of the application of fresh molluscicidal plants. In addition, for plant molluscicides, the characterization of the structures of active ingredients is also very important, which could provide the reference for the development of novel chemical molluscicides and later modifications (Whitfield 1996). However, developing novel, low-toxicity, and highly effective plant molluscicides and elucidating the possible mechanism in detail are still great challenges.

For laboratory and field testing of molluscicides for schistosomiasis (WHO (World Health Organization) 2019), we have: (1) for the new candidate molluscicide compound and for new end-use formulations of existing molluscicide compounds, an optimum effective dose should be determined based on the dose-response curve. The manufacturer's label claim may also be considered to decide the optimum dose to be tested; (2) the efficacy of exposure in immersion bioassay and residual activity at this effective dose is then determined according to the immersion bioassay. The efficacy cut-off is the $80 \%$ mortality and the effective residual action is the duration until when the mortality in treatments remains $\geq 80 \%$; (3) a dose-response curve is needed to determine $\mathrm{LC}_{50}$ and $\mathrm{LC}_{95}$ values. The results are recorded in a standard data recording form. The relationship between dose and mortality is analyzed using log-probit (Finney 1971) or logit regression; (4) from the dosages tested against a target species in the small-scale or simulated field trials, the minimum efficacious dosage (mortality and residual effect) should be selected as the optimum field application dosage for each type of habitat; (5) the WHO cut-off for the efficacy of a molluscicide formulation against adult snails is $\geq 80 \%$ mortality in $24 \mathrm{~h}$ post-exposure. The residual efficacy of the molluscicide is calculated as the duration (days) when mortality in snails remains $\geq 80 \%$.

The present mechanism investigations for chemical and natural molluscicides focus on the simple interactions between molluscicides and some enzymes, and lack visual evidence in structural biology. Therefore, investigating the structure biology of target enzymes/proteins and studying the corresponding the action sites could help in designing novel molluscicides to combat snails (Wu et al. 2006). We believe that the original and innovative molluscicides will soon emerge after the above issues are resolved by more scientists, followed by a prompt growth in advancements.

Supplementary Information The online version contains supplementary material available at https://doi.org/10.1007/s00436-021-07288-4.

Acknowledgements The work is supported by the National Natural Science Foundation of China (21867001, 22167002, 21662002 and 21602031), the Academic \&Technical Leadership Development Program of Jiangxi Province (20194BCJ22014), the Double-Thousand Talents Plan of Jiangxi Province (2019) and the Jiangxi Natural Science Foundation (20202ACBL206022, 20171BAB203010), the Science Foundation of Jiangxi Provincial Department of Education (GJJ201429), and the Graduate Innovation Research Project of Jiangxi Province (YCX20A009).

\section{Declarations}

Conflict of interest The authors declare no competing interests.

\section{References}

Abass M, Mostafa BB (2005) Synthesis and evaluation of molluscicidal and larvicidal activities of some novel enaminones derived from 4-hydroxyquinolinones: Part IX. Bioorg Med Chem 13:6133-6144

Abdelgaleil SAM, El-Aswad AF, Nakatani M (2002) Molluscicidal and anti-feedant activities of diterpenes from Euphorbia paralias L. Pest Manag Sci 58:479-482

Abdel-Gawad MM, El-Amin SM, Ohigashi H, Watanabe Y, Takeda N, Sugiyama H, Kawanaka M (2000) Molluscicidal saponins from Anagallis arvensis against schistosome intermediate hosts. Jpn J Infect Dis 53:17-19

Abdel-Rahman TM, Shalaby AA, Nassar IF (2003) Synthesis of heterobicyclic nitrogen compounds as mollusicicde agents derived from 6-methyl-5-styryl-1,2,4-triazin-3-thiol: Part I. Phosphorus Sulfur 178:279-292

Abdelrazek FM, Fathy AEDM (2005) A novel synthesis and molluscicidal activity of some functionally substituted pyridine, pyrido-[3,2-c]pyridazine, and pyrido [3,2-c]pyridazino-[2',3'-a] quinazoline derivatives. Arch Pharm Chem Life Sci 338:329-334 
Abdelrazek FM, Metz P, Farrag EK (2004) Synthesis and molluscicidal activity of 5-oxo-5,6,7,8-tetrahydro-4H-chromene derivatives. Arch Pharm Pharm Med Chem 337:482-485

Abdelrazek FM, Metz P, Metwally NH, El-Mahrouky SF (2006a) Synthesis and molluscicidal activity of new cinnoline and pyrano $[2,3-c]$ pyrazole derivatives. Arch Pharm Chem Life Sci 339:456-460

Abdelrazek FM, Michael FA, Mohamed AE (2006b) Synthesis and molluscicidal activity of some 1,3,4-Triaryl-5-chloropyrazole, pyrano[2,3-c]pyrazole, pyrazolylphthalazine and pyrano[2,3- $d]$ thiazole derivatives. Arch Pharm Chem Life Sci 339:305-312

Abdelrazek FM, Metz P, Kataeva O, Jäger A, El-Mahrouky SF (2007) Synthesis and molluscicidal activity of new chromene and pyrano[2,3-c]pyrazole derivatives. Arch Pharm Chem Life Sci 340:543-548

Adewunmi CO, Ogungbamila FO, Oluwadiya JO (1987) Molluscicidal activities of some synthetic chalcones. Planta Med 53:110-112

Ali TE, Abdel-Rahman RM, Hanafy FI, El-Edfawy SM (2008) Synthesis and molluscicidal activity of phosphorus-containing heterocyclic compounds derived from 5,6-bis (4-bromophenyl)3-hydrazino-1,2,4-triazine. Phosphorus Sulfur 183:2565-2577

Al-Sarar A, Hussein H, Abobakr Y, Bayoumi A (2012) Molluscicidal activity of methomyl and cardenolide extracts from Calotropis procera and Adenium arabicum against the land snail Monacha cantiana. Molecules 17:5310-5318

Alzabib AA, Abobakr Y, Al-Sarar AS, Hussein HI, Basudan OA, El-Gamal AA, Abdel-Kaderd MS, El-Komy MH (2019) Molluscicidal activity of cardiac glycosides isolated from Adenium obesum. Pest Manag Sci 75:2770-2775

Apers S, Baronikova S, Sindambiwe J-B, Witvrouw M, Clercq ED, Berghe D, Marck EV, Vlietinck A, Pieters L (2001) Antiviral, haemolytic and molluscicidal activities of triterpenoid saponins from Maesa lanceolata: establishment of structure-activity relationships. Planta Med 67:528-532

Bakhotmah DA (2019) Synthesis of fluorine and phosphorus compounds bearing an amino pyrimidine-substituted pyrazolo $[3,4-d]$ pyrimidine moiety as molluscicidal agents against some snails. Polycycl Aromat Comp. https://doi.org/10.1080/10406638.2019. 1625066

Barbosa TP, Camara CA, Silva TMS, Martins RM, Pinto AC, Vargasc MD (2005) New 1,2,3,4-tetrahydro-1-aza-anthraquinones and 2-aminoalkyl compounds from norlapachol with molluscicidal activity. Bioorg Med Chem 13:6464-6469

Barsoum FF, Hosnib HM, Girgisb AS (2006) Novel bis(1-acyl-2-pyrazolines) of potential anti-inflammatory and molluscicidal properties. Bioorg Med Chem 14:3929-3937

Bond HW, O'Grodnick JS, Pringle BH (1969) Tests of compounds for molluscicidal activity. VI. 4-(substituted phenoxy)-3, $\beta$-dinitrostyrenes. J Med Chem 12:1107-1108

Borkosky S, de Leóna SP, Juárez G, Sierra MG, Bardón A (2009) Molluscicidal sesquiterpene lactones from species of the Tribe vernonieae (Compositae). Chem Biodivers 6:513-519

Brackenbury TD, Appleton CC (1998) Plant molluscicides in South Africa: a registration dilemma. Parasitol Today 14:83-84

Brimer L, Elsheik S, Furu P (2007) Preliminary investigation of the disposition of the molluscicidal saponin deltonin from Balanites aegyptiaca in a snail species (Biomphalaria glabrata) and in mice. J Pestic Sci 32:213-221

Bringmann G, Holenz J, Assi LA, Zhao C, Hostettmann K (1996) Molluscicidal activity of naphthylisoquinoline alkaloids from triphyophyllum and ancistrocladus species. Planta Med 62:556-557

Bringmann G, Holenz J, Assi LA, Hostettmann K (1998) Molluscicidal activity (Biomphalariaglabrata) of Dioncophylline A: structureactivity investigations. Planta Med 64:485-486

Camara CA, Silva TMS, Da-Silva TG, Martins RM, Barbosa TP, Pinto AC, Vargas MD (2008) Molluscicidal activity of 2-hydroxy-[1,4]naphthoquinone and derivatives. An Acad Bras Ciênc 80:329-334

Cao ZG, Wang TP (2008) Research progress on snail control with drugs in China. Int J Med Parasit Dis 35:276-280 (in Chinese)

Changbunjong T, Wongwit W, Leemingsawat S, Tongtokit Y, Deesin V (2010) Effect of crude extract of Solanum xanthocarpum against snails and mosquito larvae. Southeast Asian J Trop Med Public Health 41:320-325

Chen Y, Fang P, Yi YR, Chen BP, Wang Y NYH, Ke WS (2001) Observation of influence of fluid extracted from Nerium Indicum leaves of soft tissues of Oncomelania hupensis by scanning electron microscope. Chin J Parasitol Dis Control 14:217-218 (in Chinese)

Chen SX, Wu L, Yang XM, Jiang XG, Li LG, Zhang RX, Xia L, Shao SH (2007) Comparative molluscicidal action of extract of Ginko biloba sarcotesta, arecoline and niclosamide on snail hosts of Schistosoma japonicum. Pestic Biochem Physiol 89:237-241

Chen Q, Wang WX, Ke WS, Liu X, Xiang XL (2008) Influences of stemona alkaloids on esterase isozymes activities and glycogen content in Oncomelania hupensis. Chin J Schisto Control 20:130-132 (in Chinese)

Chen Z, Wang W, Yao J, Li S, Zhang X, Hu H, Liu X, Luo B, Liu Y, Xu H, Duan L (2019) Toxicity of a molluscicide candidate PPU07 against Oncomelania hupensis (Gredler, 1881) and local fish in field evaluation. Chemosphere 222:56-61

Chen HB, Lv TX, Zhang M, Liao JX, Chang XL, Yue GZ, Li PL, Zhao XM, Qiu XY, Qian Y, Yang CP (2020) Two new compounds from the roots of Pueraria peduncularis and their molluscicidal effects on Pomacea canaliculata. J Asian Nat Prod Res 22:144-152

Colley DG, Bustinduy AL, Secor E, King CH (2014) Human schistosomiasis. Lancet 383:2253-2264

Dai J, Wu F, Gao Z, Zhang Y, Jiang Y, Xi W, Huang Y, Zhou X (2001) Study on the molluscicidal effect of shachongding against oncomelania in laboralory and field. Chin J Zoonoses 17:68-70 (in Chinese)

Dai JR, Liang YS, Li HJ, Tao YH, Tang JX (2007) Comparison of the molluscicidal effect of three formulations of niclosamide against Oncomelania snails. Chin J Schisto Control 19:179_ 182 (in Chinese)

Dai JR, Wang W, Liang YS, Li HJ, Guan XH, Zhu YC (2008) A novel molluscicidal formulation of niclosamide. Parasitol Res 103:405-412

de Abreu FC, de Paula FS, dos Santos AF, Sant'Ana AEG, de Almeida MV, Cesar ET, Trindade MN, Goulart MOF (2001) Synthesis, electrochemistry, and molluscicidal activity of nitroaromatic compounds: effects of substituents and the role of redox potential. Bioorg Med Chem 9:659-664

de Souza CP (1995) Molluscicide control of snail vectors of Schistosomiasis. Mem Inst Oswaldo Cruz 90:165-168

de Paula-Andrade C, Coelho PRS, Nascimento RAP, Mota PMPC, Romano-Silva MA, de Alvarenga KAF, Schall VT, Pimenta DN, Coelho PMZ, Oliveira E (2019) Development of a natural molluscicide prototype kit (MoluSchall) for the control of schistosomiasis mansoni transmission. Rev Soc Bras Med Trop 52:e20190252

de Souza LC, dos Santos AF, SantAna AEG, de Oliveira ID (2004) Synthesis and evaluation of the molluscicidal activity of the 5,6-dimethyl-dihydro-pyran-2,4-dione and 6-substituted analogous. Bioorg Med Chem 12:865-869

Dong Y, Du CH, Zhang Y, Wang LF, Song J, Wu MS, Yang WC, Lv S, Zhou XN (2018) Role of ecological approaches to eliminating schistosomiasis in Eryuan County evaluated by system modeling. Infect Dis Poverty 7:129

dos Santos AF, Ferraz PAL, Pinto AV, Pinto M do CFR, Goulart MOF, Sant'Ana AEG (2000) Molluscicidal activity of 
2-hydroxy-3-alkyl-1,4-naphthoquinones and Derivatives. Int J Parasitol 30: 1199-1202

dos Santos AF, Ferraz PAL, de Abreu FC, Chiari É, Goulart MOF, Sant'Ana AEG (2001) Molluscicidal and trypanocidal activities of lapachol derivatives. Planta Med 67:92-93

dos Santos AF, Sant'Ana AEG (1999) Molluscicidal activity of the diterpenoids jatrophone and jatropholones A and B isolated from Jatropha elliptica (Pohl) Muell. Arg Phytother Res 13:660-664

Ekabo OA, Farnsworth NR (1996) Antifungal and molluscicidal saponins from Serjania salzmanniana. J Nat Prod 59:431-435

El Bardicy S, El Sayed I, Yousif F, Van der Veken P, Haemers A, Augustyns K, Pieters L (2012) Schistosomicidal and molluscicidal activities of aminoalkylamino substituted neo- and norneocryptolepine derivatives. Pharm Biol 50:134-140

El Shehry MF, Abu-Hashem AA, El-Telbani EM (2010a) Synthesis of 3-((2,4-dichlorophenoxy)methyl)-1,2,4-triazolo(thiadiazoles and thiadiazines) as anti-inflammatory and molluscicidal agents. Eur J Med Chem 45:1906-1911

El Shehry MF, Swellem RH, Abu-Bakr SM, El-Telbani EM (2010b) Synthesis and molluscicidal evaluation of some new pyrazole, isoxazole, pyridine, pyrimidine, 1,4-thiazine and 1,3,4-thiadiazine derivatives incorporating benzofuran moiety. Eur J Med Chem 45:4783-4787

El-Bayouki KAM, Basyouni WM (1988) New thiazolo[5,4- $d$ ]pyrimidines with molluscicidal properties. Bull Chem Soc Jpn 61:3794-3796

El-Sakka IA, Zeid IF, Abdel-Bary HM, Abdel-Mageed AES (1994) Reactions with thiaxanthen-9-01: new thiaxanthene derivatives with molluscicidal and nematocidal activity. Arch Pharm (weinheim) 327:133-135

Fadda AA, Abdel-Latif E, El-Mekawy RE (2009) Synthesis and molluscicidal activity of some new thiophene, thiadiazole and pyrazole derivatives. Eur J Med Chem 44:1250-1256

Feng JC, Luo SL, Yang JM, Yang YY (2008) EST Isoenzymes of Oncomelania hupensis affected by Alternanthera philoxeroides. Environ Sci Technol 31:5-7 (in Chinese)

Fenwick A (1987) The role of molluscicides in schistosomiasis control. Parasitol Today 3:70-73

Finney DJ (1971) Probit analysis. Cambridge University Press, London

Giri S, Mishra AK (1984a) Fungicidal and molluscicidal activity of some 3-substituted 4-hydroxycoumarin derivatives. J Agric Food Chem 32:759-762

Giri S, Mishra AK (1984b) Fungicidal and molluscicidal activity of some heteroarylcarbinols and ethylenes. J Agric Food Chem $32: 762-765$

Gonnert R (1961) Results of laboratory and field trials with molluscicide Bayer 73. Bull Wld Hlth Org 25:483-501

Gryseels B, Polman K, Clerinx J, Kestens L (2006) Human schistosomiasis. Lancet 368:1106-1118

Guo W, Zheng LY, Wu YQ, Fan XL (2008) Synthesis and cercaricidal activities of a serial of novel self-diffused cercaricides derived from niphensamide. Chin Chem Lett 19:406-408

Guo D, Chen J, Liu Y, Yao H, Han FA, Pan J (2011) A high-performance molluscicidal ingredient against Oncomelania hupensis produced by a rhizospheric strain from Phytolacca acinosa Roxb. Pharmacogn Mag 7:277-283

Guo W, Zheng LY, Wu RM, Fan XL (2015) Design, synthesis, and cercaricidal activity of novel high-efficient, low-toxic self-spreading PEG $-\mathrm{N}$-salicylanilide derivatives against cercariae larvae of Schistosome Japonicum floating on the water surface. Chem Biol Drug Des 85:527-533

Guo W, Zheng LY, Li YD, Wu RM, Chen Q, Yang DQ, Fan XL (2016) Discovery of molluscicidal and cercaricidal activities of 3-substituted quinazolinone derivatives by a scaffold hopping approach using a pseudo-ring based on the intramolecular hydrogen bond formation. Eur J Med Chem 115:291-294

Han B, Chen J (2014) Acacetin-7-rutinoside from Buddleja lindleyana, a new molluscicidal agent against Oncomelania hupensis. Z Naturforsch C 69:186-190

Han BX, Guo DZ, Chen J, Mao J (2012) Effects of AIBL on Oncomelania hupensis, the intermediate snail host of Schistosoma japonicum: an enzyme histochemical study. Asian Pac J Trop Med 5:966-969

Hang PY, Dai JR, Liang YS, Wang R (2001) Study on influence of B002 and niclosamide to nitric oxide synthase in Oncomelania snail. Chin J Schito Control 13:278-279 (in Chinese)

Hassan GS, Hegazy GH, Safwat HM (2006) Synthesis of furo-salicylanilides and their heterocyclic derivatives with anticipated molluscicidal activity. Arch Pharm Chem Life Sci 339:448-455

Hassan SE, Rahman EHA, El Monem ARA (2010) Molluscicidal activity of butanol fraction of Meryta denhamii flowers against Lymnaea natalensis and Biomophalaria alexandrina. Global Vet $4: 15-21$

He J, Wang H, Wu M, Chen X, Shu Q, Tao W, Xu Y, Zhang S (2007) Observation on the molluscicidal effect of niclosamide ethanolamine salt dustable powder by dusting in fields. J Trop Dis Parasitol 5(153-154):172 (in Chinese)

He P, Wang W, Sanogo B, Zeng X, Sun X, Lv Z, Yuan D, Duan L, Wu Z (2017) Molluscicidal activity and mechanism of toxicity of a novel salicylanilide ester derivative against Biomphalaria species. Parasite Vector 10:383

Hoffman DO, Zakhary R (1953) The relationship of exposure time to the molluscicidal activity of copper sulfate. Am J Trop Med Hyg 2:332-336

Huang YX (2019a) Strengthening the research on novel molluscicides to accelerate the progress towards elimination of schistosomiasis. Chin J Schisto Control 31:107-108 (in Chinese)

Huang YX (2019b) Research and field application of molluscicides in China. Chin J Schisto Control 31:679-684 (in Chinese)

Jia TW, Wang W, Sun LP, Lv S, Yang K, Zhang NM, Huang XB, Liu JB, Liu HC, Liu RH, Gawish FA, Habib MR, El-Emam MA, King CH, Zhou XN (2019) Molluscicidal effectiveness of LuoWei, a novel plant-derived molluscicide, against Oncomelania hupensis, Biomphalaria alexandrina and Bulinus truncates. Infect Dis Poverty 8:27

Kady MM, Brimer L, Furu P, Lemmich E, Nielsen HM, Thiilborg ST, Thastrup O, Christensen SB (1992) The molluscicidal activity of coumarins from Ethulia conyzoides and of Dicumarol. Planta Med 58:334-337

Kajihara N, Horimi T, Minai M, Hosaka Y (1979) Laboratory assessment of the molluscicidal activity of B-2, a new chemical against Oncomelania nosophora. Jpn J Med Sci Biol 32:185-188

Kanawade S, Toche RB, Patil SP, Desai AE, Bhamare SS (2011) Aminothiophenedicarboxamides and dicyanothiopheneacetamides as effective synthetic molluscicides against Indoplanorbis exustus snail. Eur J Med Chem 46:4682-4686

Karunamoorthi K, Bishaw D, Mulat T (2008) Laboratory evaluation of Ethiopian local plant Phytolacca dodecandra extract for its toxicity effectiveness against aquatic macroinvertebrates. Eur Rev Med Pharmacol Sci 12:381-386

Ke W, Wang W, Yang Y, Ma A, Liang H, Chen Y (1999) The electron microscopy scanning on injuring of head, foot and liver of Oncomelania hupensis by Pterocarya stenoptera. J Hubei Univ Nat Sci 21:383-385 (in Chinese)

Ke W, Yang Y, Chen Q, Wang W, Ma A (2000) Effect of water extract of Pterocarya stenoptera and Rumex japonicas on liver functions of Oncomelania hupensis. J Hubei Univ Nat Sci 22:77-79 (in Chinese) 
Ke WS, Yang JL, Xiong ZT (2006) The toxicity effect of Arisaema erubescens schott on Oncomlania hupensis. Asian J Ecotoxicol 1:283-288 (in Chinese)

Kenawy ER, Rizk ES (2004) Polymeric controlled release formulations of niclosamide for control of Biomphalaria alexandrina, the vector snail of Schistosomiasis. Macromol Biosci 4:119-128

Kenawy ER, Harras SF, Rizk EST, Mona MH, ElMehlawy MH (2020) New polymeric molluscicide-attractant (niclosamide-Lglutamate) for control of Biomphalaria alexandrina. Egyptian $\mathbf{J}$ Aquatic Res 46:13-18

King CH, Sutherland LJ, Bertsch D (2015) Systematic review and meta-analysis of the impact of chemical-based mollusciciding for control of Schistosoma mansoni and $\mathrm{S}$ haematobium transmission. PLoS Negl Trop Dis 9:e0004290

Kubo I, Matsumoto T, Klocke JA, Kamikawa T (1984a) Molluscicidal and insecticidal activities of isobutylamides isolated from Fagara macrophylla. Experientia 40:340-341

Kubo I, Matsumoto T, Kozuka M, Chapya A, Naoki H (1984b) Quinolizine alkaloids from the African medicinal plant Calpurnia aurea: molluscicidal activity and structural study by 2D-NMR. Agric Biol Chem 48:2839-2841

Kujime H, Yamagiwa Y, Kamikawa T (1992) Molluscicidal acridone alkaloids from Angostura paniculata: isolation, structures, and synthesis. J Nat Prod 55:1112-1117

Lahlou M (2004) Study of the molluscicidal activity of some phenolic compounds: structure-activity relationship. Pharm Biol 42:258-261

Lardans V, Dissous C (1998) Snail control strategies for reduction of schistosomiasis transmission. Parasitol Today 14:413-417

Li WG, Huang SX, Xu MX, Jiang YM, Hu LL, Gao ZQ, Cheng ZY, Wang Y, Zhou HL, Zhan ZW (1997) Ultrastructural changes of cerebral ganglion of Oncomelania hupensis after immersion in niclosamide. Chin J Parasite Dis Control 10:42-45 (in Chinese)

Li J, Qian WH, Huang YX, Jiang ZK, Zhang KY (2002) Advance of plant molluscicide studies. Chin J Schisto Control 14:67-69 (in Chinese)

Li H, Liang Y, Dai J, Xu M, Ru W, Xu Y (2006) Enzyme-histochemical observation on influence of suspension concentrate of niclosamide in Oncomelania hupensis snails. Chin J Schisto Control 18:427-430 (in Chinese)

Li ZJ, Ge J, Dai JR, Wen LY, Lin DD, Madsen H, Zhou XN, Lv S (2016) Biology and control of snail intermediate host of Schistosoma japonicum in the People's Republic of China. Adv Parasit 92:197-236

Liang S, Abe EM, Zhou XN (2018) Integrating ecological approaches to interrupt schistosomiasis transmission: opportunities and challenges. Infect Dis Poverty 7:124

Lima NMF, dos Santos AF, Porfírio Z, Goulart MOF, Sant'Ana AEG (2002b) Toxicity of lapachol and isolapachol and their potassium salts against Biomphalaria glabrata, Schistosoma mansoni cercariae. Artemia salina and Tilapia nilotica. Acta Trop 83:43-47

Lima NMF, Correia CS, Ferraz PAL, Pinto AV, Pint, M do CRF, Santana AEG, Goulart MOF (2002a) Molluscicidal hydroxynaphthoquinones and derivatives: correlation between their redox potentials and activity against Biomphalaria glabrata. J Braz Chem Soc 13:822-829

Limpanont Y, Phuphisut O, Reamtong O, Adisakwattana P (2020) Recent advances in Schistosoma mekongi ecology, transcriptomics and proteomics of relevance to snail control. Acta Trop 202:105244

Liu HC, Chen W, Mi LX, Yang XX, Tu ZB (2001) Studies on the molluscicidal effect of Dioscorea zingiberensis against Oncomelania hupensis. Chin J Parasitol Parasit Dis 19:126-127 (in Chinese)

Lo NC, Gurarie D, Yoon N, Coulibaly JT, Bendavid E, Andrews JR, King CH (2018) Impact and cost-effectiveness of snail control to achieve disease control targets for schistosomiasis. P Natl Acad Sci USA 115:E584-E591

Madsen H (1990) Biological methods for the control of freshwater snails. Parasitol Today 6:237-241

Mahmoud MB, Ibrahim WL, Abou-El-Nour BM, El-Emam MA, Youssef AA (2011) Biological and biochemical parameters of Biomphalaria alexandrina snails exposed to the plants Datura stramonium and Sesbania sesban as water suspensions of their dry powder. Pestic Biochem Physiol 99:96-104

Marston A, Msonthi JD, Hostettmann K (1984) Naphthoquinones of diospyros usambarensis; their molluscicidal and fungicidal activities. Planta Med 50:279-280

McCullough FS, Gayral P, Duncan J, Christie JD (1980) Molluscicides in schistosomiasis control. B World Health Organ 58:681-689

Mello-Silva CC, Vilar MM, de Vasconcellos MC, Pinheiro J, de A Rodrigues ML (2010) Carbohydrate metabolism alterations in Biomphalaria glabrata infected with Schistosoma mansoni and exposed to Euphorbia splendens var. hislopii latex. Mem Inst Oswaldo Cruz 105:492-495

Molla E, Giday M, Erko B (2013) Laboratory assessment of the molluscicidal and cercariacidal activities of Balanites aegyptiaca. Asian Pac J Trop Biomed 3:657-662

Moon AP, Frick LP, Asakura S (1958) Laboratory screening of compounds for molluscicidal activity against Oncomelania nosophora with an immersion test and a modified plate test. Am J Trop Med Hyg 7:295-297

Nabih I, Metri J (1973) Structure and activity in molluscicides IV: new substituted tetralins with potential molluscicidal effect. J Pharm Sci 62:323-325

Nawwar GAM (1994) Salicylamides containing amino acid or pyran moieties with molluscicidal activity. Arch Pharm 327:201-205

Nawwar GAM, Haggag BM, Swellam RH (1993) Synthesis and molluscicidal activity of new derivatives of 1-(hydroxy/substituted phenyl)-3-arylpropenones. Arch Pharm 326:831-836

Nawwar GAM, Swellem RH, Ibrahim AM (1994) Oxazole, pyrazole and piperidine derivatives having an $o$-hydroxy-aryl moiety with anticipated molluscicidal activity. Arch Pharm Res 17:66-70

Nie WY, Tan P, Zhang XJ, Yi TJ (2009) Progresses in researches on plant-derived molluscacides. Nat Prod Res Dev 21:273-278 (in Chinese)

Nihei KI, Ying BP, Murakami T, Matsuda H, Hashimoto M, Kubo I (2005) Pachyelasides A-D, novel molluscicidal triterpene saponins from Pachyelasma tessmannii. J Agric Food Chem 53:608-613

Njoroge M, Njuguna NM, Mutai P, Ongarora DSB, Smith PW, Chibale K (2014) Recent approaches to chemical discovery and development against malaria and the neglected tropical diseases human African trypanosomiasis and schistosomiasis. Chem Rev 114:11138-11163

Nofal ZM, Fahmy HH, Mohamed HS (2002) Synthesis, antimicrobial and molluscicidal activities of new benzimidazole derivatives. Arch Pharm Res 25:28-38

Ohmae H, Iwanaga Y, Nara T, Matsuda H, Yasuraaok K (2003) Biological characteristics and control of intermediate snail host of Schistosoma japonicum. Parasitol Int 52:409-417

Peng F, Liu L, Huang Q, Liu N, Yang H, Sun H, Hu Q, Feng F, Jiang C (2011) Molluscicidal effect of Eomecon chionantha alkaloids against Oncomelania hupensis snails. Southeast Asian J Trop Med Public Health 42:289-296

Pereira AR, Etzbach L, Engene N, M€ulle R, Gerwick WH (2011) Molluscicidal metabolites from an assemblage of Palmyra Atoll cyanobacteria. J Nat Prod 74:1175-1181

Perrett S, Whitfield PJ (1996) Currently available molluscicides. Parasitol Today 12:156-159 
Pointier JP, Jourdane J (2000) Biological control of the snail hosts of schistosomiasis in areas of low transmission: the example of the Caribbean area. Acta Trop 77:53-60

Pu ZQ, Huang JS, Liu J, Zhang YP (2008) Research progress in the mechanism of the plant snail control. J Anhui Agri Sci 36:5724-5726

Radwan MA, El-Zemity SR, Mohamed SA, Sherby SM (2008) Potential of some monoterpenoids and their new $N$-methyl carbamate derivatives against Schistosomiasis snail vector, Biomphalaria alexandrina. Ecotoxicol Environ Saf 71:889-894

Rawi SM, El-Gindy H, Abd-El-Kader A (1996) New possible molluscicides from Calendula micrantha officinalis and Ammi majus. Ecotoxicol Environ Saf 35:261-267

Ribeiro KAL, de Carvalho CM, Molina MT, Lima EP, López-Montero E, Reys JRM, de Oliveira MBF, Pinto AV, Santana AEG, Goulart MOF (2009) Activities of naphthoquinones against Aedes aegypti (Linnaeus, 1762) (Diptera: Culicidae), vector of dengue and Biomphalaria glabrata (Say, 1818), intermediate host of Schistosoma mansoni. Acta Trop 111:44-50

Schönberg A, Latif N (1954) Furochromones and coumarins. XI. The molluscicidal activity of bergapten, isopimpinillin and xanthotoxin. J Am Chem Soc 76:6208

Silva TMS, Camara CA, Barbosa TP, Soares AZ, da Cunha LC, Pinto AC, Vargas MD (2005) Molluscicidal activity of synthetic lapachol amino and hydrogenated derivatives. Bioorg Med Chem 13:193-196

Singh A, Singh VK (2009) Molluscicidal activity of Saraca asoca and Thuja orientalis against the fresh water snail Lymnaea acuminate. Vet Parasitol 164:206-210

Sturrock RF (1995) Current concepts of snail control. Mem Inst Oswaldo Cruz 90:241-248

Sukumaran D, Parashar BD, Gupta AK, Jeevaratnam K, Prakash S (2004) Molluscicidal effect of nicotinanilide and its intermediate compounds against a freshwater snail lymnaea luteola, the Vector of Animal Schistosomiasis. Mem Inst Oswaldo Cruz 99:205-210

Sun H, Huang Q, Peng F, Liu N, Xu X, Hu Q, Feng F (2005) Effect of Eomecon chionantha alkaloids on ultrastructure of genital system of Oncomelania hupensis. Chin J Schisto Control 17:377-378 (in Chinese)

Sun WX, Yuan SS, Huang QY, Peng F, Liu NM, Yang SQ (2011) Study on liver injury of Oncomelania hupensis caused by Eomecon chinanthe sanguinarine. Chin J Schisto Control 23:82-84 (in Chinese)

Tan P, He C, Liu B, Chang H, Deng W (2001) SEM Observation of the changes of the head and foot's muscle of Oncomelania hupensis after exposed to mixture of arecoline with molluscicides. Chin $\mathbf{J}$ Schisto Control 13:21-23 (in Chinese)

Thétiot-Laurent SAL, Boissier J, Robert A, Meunier B (2013) Schistosomiasis Chemotherapy. Angew Chem Int Ed 52:7936-7956

Tiwari F (2012) Bait formulation toxicity of plant derived molluscicides in attractant food pellets against vector snail. Lymnaea Acuminate World J Zool 7:54-59

Vasconcellos ML, Silva TM, Camara CA, Martins RM, Lacerda KM, Lopes HM, Pereira VL, de Souza RO, Crespo LT (2006) BaylisHillman adducts with molluscicidal activity against Biomphalaria glabrata. Pest Manag Sci 62:288-292

Vinaud MC, Lino RS Jr, Bezerra JCB (2008) Activity of Stryphnodendron polyphyllum, a plant from the Brazilian savannah, against hemocytes of Biomphalaria glabrata, an intermediate host of Schistosoma mansoni. Rev Patol Trop 37:237-246

Wang G, Shen B, Wang J, Song G (1997) Influence of the seed of Camellia sinensis (L) O. Kuntze on the tegument of soft tissues of Oncomelania hupensis. Chin J Parasitol Parasit Dis 15:243245 (in Chinese)

Wang H, Cai WM, Wang WX, Yang JM (2006) Molluscicidal activity of Nerium Indicum Mill, Pterocarya stenoptera DC, and Rumex japonicum Houtt on Oncomelania hupensis. Biomed Environ Sci 19:245-248 (in Chinese)

Wang LD, Chen HG, Guo JG, Zeng XJ, Hong XL, Xiong JJ, Wu XH, Wang XH, Wang LY, Xia G, Hao Y, Chin DP, Zhou XN (2009) A strategy to control transmission of Schistosoma japonicum in China. N Engl J Med 360:121-128

Wang W, Qin Z, Zhu D, Wei Y, Li S, Duan L (2016) Synthesis, bioactivity evaluation, and toxicity assessment of novel salicylanilide ester derivatives as cercaricides against Schistosoma japonicum and molluscicides against Oncomelania hupensis. Antimicrob Agents Chemother 60:323-331

Wang W, Zhang X, Zhang H, Hu H, Li S, Liu X, Duan L (2017) Field evaluation of a novel molluscicide (niclosamidate) against Oncomelania hupensis, intermediate host of Schistosoma japonicum. Parasitol Res 116:3423-3427

Wang W, Mao Q, Yao J, Yang W, Zhang Q, Lu W, Deng Z, Duan L (2018) Discovery of the pyridylphenylureas as novel molluscicides against the invasive snail Biomphalaria straminea, intermediate host of Schistosoma mansoni. Parasite Vector 11:291

Wei WY, Bao ZP, Li GP, Lü GL, Xia M, Guo JG (2008) Study on molluscicidal effect of calcium cyanamide. Chin J Schisto Control 20:54-57 (in Chinese)

Whitfield PJ (1996) Novel anthelmintic compounds and molluscicides from medicinal plants. Trans R Soc Trop Med Hyg 90:596-600

WHO (World Health Organization) (1993) The control of Schistosomiasis: second report of the WHO expert committee. WHO Tech Rep Series 830:1-86

WHO (World Health Organization) (2019) Guidelines for laboratory and field testing of molluscicides for control of schistosomiasis. Licence: CC BY-NC-SA 3.0 IGO

WHO (World Health Organization) (2021) https://www.who.int/ news-room/fact-sheets/detail/schistosomiasis

Wu F (2007) Progress of research on molluscicidal effect of nereistoxin pesticide. Chin J Schisto Control 19(482-484):487 (in Chinese)

Wu F, Chen Y, Dai J, Zhou X, Gao Z (1998) Molluscicidal effect of evisect against snail and its ova. J Practical Parasitic Dis 6:31-33 (in Chinese)

Wu XY, Yang LQ, Zhang LH, Ge QJ (2006) Progress of research on molluscicides. Chin J Schisto Control 18:474-476 (in Chinese)

Xi WP, Wu F, Jiang YJ, Huang YX (2000) Observation on the effect of four molluscicides eliminating snails. Chin J Schisto Control 12:11 (in Chinese)

Xi Y, Dong XL, Meng Z, Zhu ZL, Zhang SX (2016) A study on the development toxicity and genetoxicity induced by sodium pentachlorophenate. Prev Med 28:1081-1087 (in Chinese)

Xia M, Ding L, Wei WY, Li GP, Guo FY, Chen XL, Guo JG (2010) Histological and morphological changes of Oncomelania hupensis snails by calcium cyanamide. Chin J Schisto Control 22:174175 (in Chinese)

Xia J, Yuan Y, Xu X, Wei F, Li G, Liu M, Li J, Chen R, Zhou Z, Nie $S$ (2014) Evaluating the effect of a novel molluscicide in the endemic Schistosomiasis japonica area of China. Int J Environ Res Public Health 11:10406-10418

Xiong T, Zhao QP, Xu XJ, Liu R, Jiang MS, Dong HF (2016) Morphological and enzymatical observations in Oncomelania hupensis after molluscicide treatment: implication for future molluscicide development. Parasitol Res 115:4139-4152

Xiong T, Zhao QP, Liu R, Jiang MS, Dong HF (2018) Enzymology of snails under treatment of molluscicides. Chin J Schisto Control 30(237-240):243 (in Chinese)

Xu FS, Xi JY, Gu XG, Yin HZ, Mao Y (2003) Effect of dipterex for killing schistosome egg and snail. Parasitoses Infect Dis 1:28-30 (in Chinese) 
Xu SF, Wang H, Jiang LX (2005) Progress of research on various preparations of niclosamide and snail control. Chin J Schisto Control 17:478-480 (in Chinese)

Xu XJ, Yuan Y, Li CL, Wei FH, Zhao YB, Tu ZW, Liu M, Cao MM, He H, Fan HP (2007) Molluscicidal effect of a novel molluscicide, LDS. Chin J Schisto Control 19:328-333 (in Chinese)

Yang X, Chen S, Xia L, Chen J (2008) Molluscicidal activity against Oncomelania hupensis of Ginkgo biloba. Fitoterapia 79:250-254

Yang GJ, Li W, Sun LP, Wu F, Yang K, Huang YX, Zhou XN (2010) Molluscicidal efficacies of different formulations of niclosamide: result of meta-analysis of Chinese literature. Parasite Vector 3:84

Yang GJ, Sun LP, Hong QB, Zhu HR, Yang K, Gao Q, Zhou XN (2012) Optimizing molluscicide treatment strategies in different control stages of schistosomiasis in the People's Republic of China. Parasite Vector 5:260

You BR, Huang YX, Hu HG, Hang DR, Jing SB, Mei QF (2016) Molluscicidal effect of niclosamide ethanolamine salt powdergranula against Oncomelania hupensis. Chin J Schisto Control 28:237-240 (in Chinese)

Younes A, El-Sherief H, Gawish F, Mahmoud M (2017) Biological control of snail hosts transmitting schistosomiasis by the water bug, Sphaerodema urinator. Parasitol Res 116:1257-1264

Yuan Y, Xu XJ, Dong HF, Jiang MS, Zhu HG (2005) Transmission control of schistosomiasis japonica: implementation and evaluation of different snail control interventions. Acta Trop 96:191-197

Yuan Y, Dong H, Xu X, Li G, Wei F, Zhao Y, Tu Z, Liu M, Cao M, He H, Tang L, Zhu H, Fan H (2011) Evaluation of a new molluscicide for counteracting the intermediate snail host of schistosoma japonicum. Malacologia 53:217-227

Zhang HM, Tan YG, Li XM, Jiang H, Yuan TQ, Lin R, Huang FM, Wei ZW (2006) Laboratory and field observation on the molluscicidal effect of a new formula of sodium pentachlorophenate on Oncomelania hepensis from mountainous area in Guangxi. Chin Trop Med 6:966-967 (in Chinese)

Zhang Y, Zhu D, Li H-J, Liu H-X, Liang Y-S, Xu X-N, Li W-X (2007) Mechanism of action of a plant molluscicide HL on Oncomelania hupensis. Chin J Zoonoses 23:978-981 (in Chinese)
Zhang P, Pan J, Duan W, Li X, Zhang Y, Zhou Y, Jiang Q, Mao Z, Yu P (2011) Synthesis of ginkgolic acid analogues and evaluation of their molluscicidal activity. Molecules 16:4059-4069

Zhang X, Zhang H-M, Liu X, Rong X-B, Yang R (2013) Molluscicidal effect of 10\% LDS in fields. Chin J Schisto Control 25(182183):186 (in Chinese)

Zhang LJ, Xu ZM, Guo JY, Dai SM, Dang H, Lü S, Xu J, Li SZ, Zhou XN (2019) Endemic status of schistosomiasis in People's Republic of China in 2018. Chin J Schisto Control 31:576-582 (in Chinese)

Zhu DP, Gu JR, Yin SY, Hong GB, Chen PL, Guo YH (1984) Study on a new mollusccide, bromoacetamide. Chin J Parasitol Parasit Dis 2:17-20 (in Chinese)

Zhu D, Zhou XN, Zhang SQ, Zhang G, Liu HX, Lu DB, Cai GY, Ni QZ, Cao ZG, Wu WD (2006) Study on the molluscicidal effect of META-Li against Oncomelania hupensis. Chin J Parasitol Parasit Dis 24:200-203 (in Chinese)

Zhu D, Li HJ, Liu HX, Zhang Y, Guo J, Liang YS, Zhou XN (2007) Enzyme histochemistry: the effect of META-Li on Oncomelania hupensis. Chin J Parasitol Parasit Dis 25:198-201 (in Chinese)

Zhu GY, Zu DL, Guan YG, Yang WD, Lu YH (2010) Experimental study and application of molluscicidal constituents and mechanisms in plants. Chin J Vector Biol Control 21:509-511 (in Chinese)

Zou FC, Duan G, Xie YJ, Zhou Y, Dong GD, Lin RQ, Zhu XQ (2009) Molluscicidal activity of the plant Eupatorium adenophorum against Oncomelania hupensis, the intermediate host snail of Schistosoma japonicum. Ann Trop Med Parasitol 103:549-553

Publisher's note Springer Nature remains neutral with regard to jurisdictional claims in published maps and institutional affiliations. 